\title{
WORLD LITERATURE AT THE INTERSECTION OF CULTURES AND CIVILIZATIONS
}

\author{
Collective monograph
}

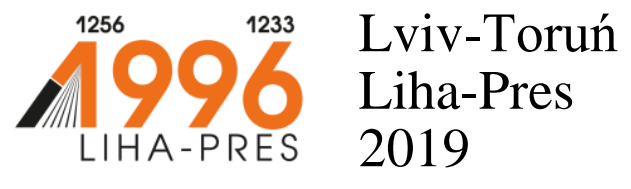




\section{Reviewers:}

dr Adam Wróbel, School of Polish Language and Culture of Cuiavian University in Wloclawek (Republic of Poland);

mgr Joanna Skiba, Director of the Center for Foreign Languages, Cuiavian University in Włocławek (Republic of Poland).

World literature at the intersection of cultures and civilizations : collective monograph / H. I. Bokshan, N. I. Ilinska, O. V. Keba, J. O. Pomohaibo, etc. - Lviv-Toruń : Liha-Pres, 2019. - 116 p.

ISBN 978-966-397-139-1

Liha-Pres is an international publishing house which belongs to the category "C" according to the classification of Research School for Socio-Economic and Natural Sciences of the Environment (SENSE) [isn: 3943, 1705, 1704, 1703, 1702, 1701; prefixMetCode: 978966397]. Official website - www.sense.nl. 


\section{CONTENTS}

THE MYTH OF THE FAIRY LOVER

IN THE NOVELS "THE UNICORN"

BY IRIS MURDOCH, "THE ENCHANTED MUSICIANS"

BY HALYNA PAHUTIAK AND "LIUTETSIIA"

BY YURII VYNNYCHUK

Bokshan H. I.

STRATEGIES OF MYTH-MAKING

IN THE HISTORICAL AND PHILOSOPHICAL

DISCOURSE OF THE NOVEL "THE WANDERING JEW"

BY S. HEYM

Ilinska N. I. .18

MAPPING SPACE IN FICTION

OF ANDREI PLATONOV

Keba O. V. .36

THE GERMAN INTERCULTURAL NOVEL

OF THE $21^{\text {ST }}$ CENTURY. «THE GREAT HOMECOMING»

BY ANNA KIM

Pomohaibo J. O.

AUTHOR'S CONCEPT OF SELF-CONSCIOUSNESS

IN THE NOVEL "THE ENDLESS DEADLOCK"

BY DMITRY GALKOVSKY

Shtepenko O. 
THE RULERS OF EARLY KIEVAN RUS IN T. BABITSKAYA'S STORY "PRINCESS OLGA": LITERARY CONTEXT AND PECULIARITIES OF THE AUTHOR'S INTERPRETATION OF THE SOURCE BASE AND HISTORIOGRAPHICAL EXPERIENCE

Vysotsky A. A................................................................................................ 91 


\section{THE MYTH OF THE FAIRY LOVER IN THE NOVELS "THE UNICORN" BY IRIS MURDOCH, "THE ENCHANTED MUSICIANS" BY HALYNA PAHUTIAK AND "LIUTETSIIA" BY YURII VYNNYCHUK}

\section{Bokshan H. I.}

\section{INTRODUCTION}

The mysterious figures and motifs of the Celtic mythology have inspired writers to create numerous characters and construct multiple plots of the world literature. The Celtic myths are an inexhaustible source of the poetics of fantasy books. It seems quite natural when they are adopted and incorporated by the authors whose biography is geographically or ethnically related to Ireland. For instance, in Iris Murdoch's fiction, namely in her novel "The Unicorn", the reception of the Celtic mythology is obvious, since the writer was born in Ireland. We share J. Jarząb's opinion who underlines that "throughout her life, Murdoch always took pride in her Irish roots"1. However, there are some Ukrainian authors, whose literary works manifest an overwhelming interest in the Celtic folkloric stories on the level of their mythopoetics. The renowned Ukrainian writer, the Shevchenko prize winner of 2010, Halyna Pahutiak finds a striking similarity of the Carpathian landscapes and the Irish sceneries, and also feels "the Celtic magic" in the lands of boikos, one of the Western Ukrainian ethnic groups, therefore she "sought the decoration for her future novel about Those flying in the air" ${ }^{2}$ in her native Drohobych region. The writer's essays contain the stories about the supernatural beings, in particular, elves, dancing on the valleys near the cave Pryima at night $^{3}$. The author also relates the recurring character of her novels - The Gentleman in a black suit with lustrous buttons - to the figures of the Celtic folklore, "called fairies by the British people"4. Another famous Ukrainian writer Yurii Vynnychuk, the prominent popularizer of the Celtic

${ }^{1}$ Jarząb J. The Significance of Space in Iris Murdoch's "The Unicorn" as a TwentiethCentury Irish Gothic Novel. Studia Anglica Posnaniensia. Issue 49/4. 2014. P. 5.

${ }^{2}$ Пагутяк Г. Сентиментальні мандрівки Галичиною. Львів : ЛА «Піраміда», 2014. C. 146 .

${ }^{3}$ Пагутяк Г. Сентиментальні мандрівки Галичиною. С. 153.

${ }^{4}$ Пагутяк Г. Уріж та його духи. Львів : ЛА «Піраміда», 2012. С. 54. 
culture, published the so-called translation of the Irish poem of the XIII century "Crying over Kyi's town" which proved to be mystification. This author's trick was explained by the desire to maintain the hypothesis shared by some scientists, I. Kachurovskyi in particular, that there are the Celts' traces in the Ukrainian ethnogenesis: "Between the 6th and the 2nd centuries B.C. there was a so-called "biological explosion": the Celtic peoples occupied nearly all the middle Europe. $<\ldots>$ In Western Ukraine the cult of the Goddess Dana has been left since that time",

The poetics of the novels "The Unicorn" by I. Murdoch, "The Enchanted Musicians" by H. Pahutiak and "Liutetsiia" by Yu. Vynnychuk have been objects of various studies of the Ukrainian scholars: S. Pavlychko considered the novel of the Irish writer as "the embodiment of the author's concept of human fortune and freedom"6; N. Bukina characterized Gothic elements in "The Enchanted Musicians" in the light of gender problems ${ }^{7}$ and identified typological analogies of H. Pahutiak's fairy-novel and H. Walpole's "The Castle of Otranto" ${ }^{2}$; 2]; O. Romanenko outlined the functions of oneiric motifs and determined their role creating a unique chronotope in the Ukrainian author's work ${ }^{9}$; the literary critic K. Rodyk highlighted Yu. Vynnychuk's ability to manipulate with auto-allusions and use oneiric intertexts ${ }^{10}$. In spite of the increasing interest in the fiction of I. Murdoch, H. Pahutiak and Yu. Vynnychuk in both Ukrainian and foreign literature studies, the issue of interpreting the Celtic myths in their novels has not been examined thoroughly yet. Thus, the principal objective of this paper is to reveal the specificity of adopting the Celtic mythological imagery, namely the figure of the fairy lover, in

${ }^{5}$ Качуровський І. Острів фантастів (Ірляндія та ії роля у збереженні культури). Генерика і архітектоніка. Київ : Видавничий дім «Києво-Могилянська академія», 2005. C. 40 .

6 Павличко С. Лабіринти мислення : інтелектуальний роман сучасної Великої Британії. Зарубіжна література : дослідж. та критич. статті. Київ : Вид-во Соломії Павличко «Основи», 2001. С. 297.

${ }^{7}$ Букіна Н. «Готика» в романі «Зачаровані музиканти» Галини Пагутяк під кутом зору гендерних інтерпретацій. Наукові праці. Літературознавство. 2014. Вип. 219. T. 231. C. 24-28.

8 Букіна Н. Типологія родинного прокляття та помсти в романі «Зачаровані музиканти» Галини Пагутяк. Слово $і$ час. 2013. № 6. С. 93-97.

9 Романенко О. Семантичне дзеркало сну в українській високій і масовій літературі. Вісник Київського начіонального університету імені Тараса Шевченка. Літературознавство, мовознавство, фольклористика. 2012. Вип. 23. С. 16-21.

${ }^{10}$ Родик К. Ребрендинг містифікатора: рецензія на «Лютецію» Юрія Винничука. URL: https://umoloda.kyiv.ua/number/3289/164/121666/ (Accessed: 31.07.2019). 
I. Murdoch's, H. Pahutiak's and Yu. Vynnychuk's literary prose and find out typological parallels in these authors' works.

\section{The visualization of the mythological Niamh of the Golden Hair in the portraits of the literary characters}

The embodiment of the folkloric figure of the fairy lover in I. Murdoch's novel "The Unicorn" is the lovely "prisoner" of Gaze Castle Hannah Crean-Smith, in H. Pahutiak's fairy novel "The Enchanted Musicians" her features can be traced in the Princess of Those living underground and flying in the air, and Liutetsiia is the literary projection of this mythological beauty in Yu. Vynnychuk's novel of the same name. The intertextual references to the Celtic myths, the Niamh of the Golden Hair in particular, are mainly visualized in the female characters' appearances. In the Celtic mythology red hair and green clothes are considered as indicators of fairy blood in humans ${ }^{11}$. In the portraits of Hannah CreanSmith the colour of her hair is emphasized several times throughout the novel: "She had a tangle of reddish gold hair and eyes of almost the same colour and a wide pale freckled face" ${ }^{12}$. Moreover, all the maids of the neighbouring Riders Castle also had the hair of the "fairy colour" and similarly its hostess Alice Lejour was "a beautiful redhead"". The writer highlights the beauty of Hannah Crean-Smith, this spiritual-looking character, focusing on the portrait details distinctive of fairies. When meeting Effingham Cooper, the mysterious prisoner of Gaze Castle "was wearing a short dress of dark green linen"14. The folkloric sources contain the information about the taboo on wearing red and green colours by people: "Because of their fondness of these colours, fairies were believed to take umbrage when humans wore them and could cause trouble for such miscreants" $"$.

In "The Enchanted Musicians" The Lady with fire-red hair first appeared to the young master Matvii Domnytskyi "in a puffed dress and a

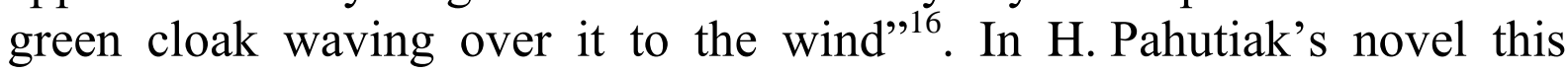
marker of fairies acquires a nominative function: the mysterious female character appears throughout the text as "The Lady with yellow/fire-red

${ }^{11}$ Monaghan P. The Encyclopaedia of Celtic Mythology and Folklore. New York: Facts on File, 2004. P. 167.

${ }^{12}$ Murdoch I. The Unicorn. London: Triad/Granada, 1982. P. 23.

${ }^{13}$ Murdoch I. The Unicorn. P. 68.

${ }^{14}$ Murdoch I. The Unicorn. P. 89.

${ }^{15}$ Monaghan P. The Encyclopaedia of Celtic Mythology and Folklore. P. 170.

${ }^{16}$ Пагутяк Г. Зачаровані музиканти. Київ : Ярославів Вал, 2010. С. 13. 
hair". The descriptive naming of the enigmatic creatures in "The Enchanted Musicians" reflects the Celtic tradition to speak about fairies using euphemisms, proving simultaneous fear and veneration towards them $^{17}$. The writer H. Pahutiak is also a red-haired woman and she feels a sort of mystical relation to fairies: "Nobody in my family has had such hair. It appeared from my grandfather's memory about the young lady, whose ghost passed over the night fire, whose restless soul probably lives in my body"18.

In one of the latest Yu. Vynnychuk's novels "Liutetsiia" (2017) the image of the Beautiful Lady recurrently appears in the oneiric visions of the narrator, who writes a novel about Ivan Vahylevych, the Ukrainian cultural figure of the $17^{\text {th }}$ century, whose dreams also portray the woman possessing the features of the Celtic fairy lover: she "did not fit his ideal of feminine beauty being a red-haired and not a blonde-haired one. She had luxuriant ginger hair"' ${ }^{\prime 19}$. On the one hand, the narrator's dreams bring him pleasure, on the other hand, they torture him because of the impossibility to take the beauty to his reality. The myths tell us that the Niamh of the Golden Hair "was so beautiful that no human man could resist her: stately, fear of feature and crowned with cascading golden locks" ${ }^{\prime 20}$. The fascinating appearance of the woman from the narrator's dreams is allusively connected with the Irish folkloric figure: "Here she gets out of the car, having long fire-red hair waving to the wind, and smiles at me, and the neighbours stare at us and cannot understand what it all means, and they are even more stunned, when this heavenly beauty hugs and kisses me" ${ }^{, 21}$. The character of the narrator's novel Ivan Vahylevych was also fascinated by the mysterious beauty having the appearance of the Niamh of the Golden Hair: "Her fire-red hair flourished in front of me like the burning bush provoking the desire to submerge my hands into it without the fear of being burnt" 22 .

Therefore, the visualization of the female characters in I. Murdoch's, H. Pahutiak and Yu. Vynnychuk's novels, which are the projections of the Celtic figure of the fairy lover, proves that there are typological parallels on the level of the characters' appearances. While interpreting it the three

\footnotetext{
${ }^{17}$ Monaghan P. The Encyclopaedia of Celtic Mythology and Folklore. P. 170.

${ }^{18}$ Пагутяк Г. Панна 3 жовтим волоссям. Потонулі в снігах. Львів : ЛА «Піраміда»,

${ }^{19}$ Винничук Ю. Лютеція. Харків : Фоліо, 2017. С. 95.

${ }^{20}$ Monaghan P. The Encyclopaedia of Celtic Mythology and Folklore. P. 358.

${ }^{21}$ Винничук Ю. Лютеція. С. 160.

${ }^{22}$ Винничук Ю. Лютеція. С. 290.
} 2010. С. 59. 
authors retained the semantic core of the mythologem and reactualized the ancient meanings according to the fictional realities of their novels.

\section{The motif of fairy kidnapping in I. Murdoch's, H. Pahutiak's and Yu. Vynnychuk's novels}

The Celtic myths portray the fairy lover as a ravishingly beautiful woman who stole away the most handsome men from this world and made them her lovers or servants. Having tasted her charms, the entrapped men used to forget their previous lives and utterly devoted themselves to romantic feelings. Fairies kidnapped not only handsome men on their wedding day, but also young girls (brides) ${ }^{23}$. In the novel "The Unicorn" each man meeting the immensely beautiful Hannah Crean-Smith (Max Lejour and his son Philip, Effingham Cooper, Gerald Scottow, Denis Nolan) started feeling passion for her. When Effingham first learnt about the imprisoned beauty of Gaze, "the lady obsessed him, she took away his calm of mind, he even began to dream about her" 24 . Describing his feelings for Hannah, he used such words as "stripped", "attuned", "keyed up"25. Mad passion entirely captivated Effingham: "But the odd spiritual tormented yet resigned beauty of Hannah seemed to him now the castle perilous toward which he had now all his days been fairing" ${ }^{26}$. Hanna's charm did not leave indifferent even the elderly host of Riders Castle - the respectable philosopher Max Lejour: in Cooper's opinion, "the imprisoned lady must somehow have occupied the old man's imagination too"27.

In "The Enchanted Musicians" the young and beautiful Dokiia was snatched away and taken to the otherworld by "the handsome and noble looking" 28 Prince of Those living underground and flying in the air, accompanied by the enchanted musicians. The Lady with fire-red hair appeared in Matvii's life in a week after his engagement with Teklia Liska. After meeting the Princess of Those living underground and flying in the air the young Domnytskyi involuntarily repudiated his previous life and started seeking the Beauty Lady who left a bleeding wound in his heart. The Prince and the Princess of Those living underground and flying in the air stole humans - both young women and men - lived with them and bore children. When Matvii came to the court Pryima, he saw their beautiful

\footnotetext{
${ }^{23}$ Monaghan P. The Encyclopaedia of Celtic Mythology and Folklore. P. 173-174.

${ }^{24}$ Murdoch I. The Unicorn. P. 70.

${ }^{25}$ Murdoch I. The Unicorn. P. 71.

${ }^{26}$ Murdoch I. The Unicorn. P. 71.

${ }^{27}$ Murdoch I. The Unicorn. P. 71.

${ }^{28}$ Пагутяк Г. Зачаровані музиканти. С. 210.
} 
daughters and sons: "Suddenly it got silent and out of the cave came gorgeous ladies followed by handsome knights - the children of the Prince, the Princess and human women and men, they had neither sorrows in their hearts, no burdens of human passions" 29 .

The dreams about Liutetsiia had a magic power over the narrator in Yu. Vynnychuk's novel: they "did not leave me, attracted and enchained my thoughts, tempted my imagination to invent more details" ${ }^{30}$. His visions seemed more valuable to him than the real life: "Almost every day I think about that wonderful world, which opens to me only partially in my dreams, and I want to know, what will happen further, I feel and believe, that Liutetsiia is the one I have always longed for, the one I have been looking for and dreaming, the one who will never betray" ${ }^{31}$. The narrator's and Vahylevych's dreams overlap and both characters feel deeply in love with the oneiric Liutetsia.

The motif of love for the Beautiful Lady in the interpretation of I. Murdoch, H. Pahutiak and Yu. Vynnychuk is more similar to the Celtic myths than to chivalric romance, where adoration is combined with bravery and heroic deeds. In "The Unicorn" the men falling in love with Hannah either manifest long-lasting passiveness or are insufficiently active in rescuing the charming prisoner, thus their attempts of saving her are doomed to failure. The dweller of the neighbouring castle Philip Lejour "watches and waits" giving up the idea to change the situation: "He went away. $<\ldots>$ He would have taken her off. He would have rescued her" ${ }^{32}$. Denis Nolan doubts "if there is anything he wants to do - now" 33 . It seemed to Effingham that "Pip derived some positive satisfaction from the spectacle of the beautiful imprisoned creature" ${ }^{, 34}$. Only after seven years of waiting had passed the younger Lejour felt ready for rescuing Hannah. Neither was Cooper capable of taking a decisive step: he was "deeply afraid of the possibility of really having to take Hannah away" "35. He did like the other role: "He was to be in love with Hannah, he was to be Hannah's servant" 36 . The inclination for desertion "to the world of ordinary life and reason" 37 is accentuated in Effingham's character therefore he is

\footnotetext{
${ }^{29}$ Пагутяк Г. Зачаровані музиканти. С. 216.

${ }^{30}$ Винничук Ю. Лютеція. С. 56.

${ }^{31}$ Винничук Ю. Лютеція. С. 57.

${ }^{32}$ Murdoch I. The Unicorn. P. 61.

${ }^{33}$ Murdoch I. The Unicorn. P. 63.

${ }^{34}$ Murdoch I. The Unicorn. P. 74.

${ }^{35}$ Murdoch I. The Unicorn. P. 72.

${ }^{36}$ Murdoch I. The Unicorn. P. 73.

${ }^{37}$ Murdoch I. The Unicorn. P. 228.
} 
not associated with a knight. We agree with S. F. Nejad's opinion that the motif of courtly love is parodied in Effingham's attachment to Hannah in "The Unicorn" "38. On the other hand, heroic features are inherent in the female character: it was Marian Taylor - the chaperon of Mrs CreanSmith - who offered Effingham to save Hannah and destroy the enchanted wall around her, "with the brutality, already growing upon her, of a desperate general" "39.

In H. Pahutiak's novel Matvii Domnytskyi character is almost entirely deprived of heroic features: he does look like a lost sleepwalker but not a valorous warrior. Though the writer compares him to a courteous knight, "who falls asleep, awakes and performs glorious deeds thinking about his Beautiful Lady" "40, the semantics of serving dominates in his character: he was "like a monk worshiping Jesus or Virgin Mary"41.

The male characters loving the red-haired Liutetsia from their dreams in Yu. Vynnychuk's novel also lack heroic qualities. The narrator, whose the only occupation is writing the novel about Vahylevych, is "an idler, a reveler" ${ }^{42}$. The character's deheroization can be traced in his selfcharacteristics: "I haven't liked to work since my early childhood" ${ }^{43}$. The narrator whose imagination was captivated by Liuteysiia's figure is hardly like a knight willing to perform heroic deeds for the sake of the Beautiful Lady: "I was anxious about being drowned in her eyes, giving up to her sight, losing my power" ${ }^{\text {" }}$. In his own novel the narrator focuses not on Ivan Vahylevych's self-devoted activity connected with Ruska Triitsia and "Rusalka Dnistrova", but on the cultural figure's personal life. He draws attention to the romantic adventures of Vahylevych who was very handsome and made many women fall in love with him. Moreover, his real love affairs were amplified with the delusions about mythical lovers who were praised in his sonnets.

Thus, the Celtic motif of fairy kidnapping is interpreted differently in the novels "The Unicorn", "The Enchanted Musicians" and "Liutetsiia". In I. Murdoch's version it is transformed into the motif of sad love: the fairy lover - Hannah Crean-Smith "steals" the men's hearts and becomes the mistress of their feelings, though they stay free physically. In H. Pahutiak's

${ }^{38}$ Nejad S. F. Intertextuality and Parody in Iris Murdoch's “The Unicorn”. International Journal of English Research. Volume 3. Issue2. 2017. P. 89.

${ }^{39}$ Murdoch I. The Unicorn. P. 125.

${ }^{40}$ Пагутяк Г. Зачаровані музиканти. С. 147.

${ }^{41}$ Пагутяк Г. Зачаровані музиканти. С. 147.

42 Винничук Ю. Лютеція. С. 14.

${ }^{43}$ Винничук Ю. Лютеція. С. 97.

${ }^{44}$ Винничук Ю. Лютеція. С. 55. 
interpretation the Princess of Those living underground and flying in the air actually snatched away young men and made them serve her as musicians or bore their children, that is an evidence of retaining the core meaning of the Celtic mythologem. Yu. Vynnychuk makes his male characters crave for meeting the Beautiful Lady in a parallel reality, since she captured their thoughts and feelings.

\section{The fairy lover as La Belle Dame sans Merci}

The figure of the fairy lover correlates with the motif of death and generates a tragic modus of the three novels. In "The Unicorn" Hannah was accused of the attempt to kill her husband Peter, her fatal bullet hit Gerald Scottow, and Philip Lejour accidentally shot himself when cleaning the gun. Miss Tailor was impressed by "a startling possessive savagery", 45 in Hannah's words about Denis Nolan: "I think he would let me kill him slowly"46. Marian also saw not only a Queen in her but also a woman "infinitely capable of crimes" 47 . Effingham Cooper called Hannah "a doomed figure", "la belle dame sans merci", "a beautiful pale vampire" attempting to kill him, "a pale death-dealing enchantress" features of the character are explicit in Hannah's words addressed to Marian: "I have battened upon you like a secret vampire"49.

In "The Enchanted Musicians", after Matvii had escaped, his father Oleksander Domnytskyi - died under weird circumstances, then the old master's friends perished, when they were seeking the young master, and later a number of enigmatic deaths occurred (the vendor's, the small boy's, the dunter's, the two vagabonds', the khatnyk's and the servant Petro's). The enchanted musicians explained Matvii that those persons' deaths were caused by the curse, impending over the Domnytskyi family: "A bloody trace is following those who get under the earth"50. The Lady with fire-red hair, like mythological fairies, is capable of revenge for the harm done to her: the misfortune could "befell those who dared cut down a fairy tree" She explained Matvii the disaster of his family: "Your grandfather cut down my tree. And his family is punished for that"

\footnotetext{
${ }^{45}$ Murdoch I. The Unicorn. P. 43.

${ }^{46}$ Murdoch I. The Unicorn. P. 43.

${ }^{47}$ Murdoch I. The Unicorn. P. 223.

${ }^{48}$ Murdoch I. The Unicorn. P. 267-268.

${ }^{49}$ Murdoch I. The Unicorn. P. 219.

${ }^{50}$ Пагутяк Г. Зачаровані музиканти. С. 208.

${ }^{51}$ Monaghan P. The Encyclopaedia of Celtic Mythology and Folklore. P. 179.

${ }^{52}$ Пагутяк Г. Зачаровані музиканти. С. 217.
} 
Such gothic arrangement of the female characters in I. Murdoch's and H. Pahutiak's novels is allusively connected with the poem of John Keats "La Belle Dame sans Merci", telling about a nameless knight and a mysterious fairy lady, and the paintings of Arthur Hughes, Frank Cadogan Cowper, Frank Dicksee and others of the same title.

$\mathrm{O}$ what can ail thee, knight-at-arms,

Alone and palely loitering?

The sedge has withered from the lake,

And no birds sing.

$<\ldots>$

I met a lady in the meads,

Full beautiful - a faery's child,

Her hair was long, her foot was light,

And her eyes were wild ${ }^{53}$.

In Yu. Vynnychuk's novel the motif of death is also connected with the figure of Liutetsiia who was one of the Letter-carriers of the Order. She explained Vahylevych that the Letter-carriers were to be killed in the real world by "Those who are on the Other Side of the Great Battle" ${ }^{\text {. This }}$ interpretation of the character essentially differs from the versions of I. Murdoch and H. Pahutiak because Liutetsia herself is a potential victim of murdering.

It is necessary to stress that the tragic accidents in I. Murdoch's and H. Pahutiak's novels are connected with the bog topos which is considered a "symbolic site" of gothic sceneries, moreover "bogs were a prominent feature of the Irish and Scottish landscape until recent times", "typical liminal zones", "perfect entrances to the other world" I. Murdoch's novel - Effingham Cooper - was fortunately rescued from drowning in the bog by Denis Nolan, who knew safe spots. In the novel of the Ukrainian writer the rapacious mud swallowed Oleksander Domnytskyi's both friends: "Lukash's horse got entrapped in the bog hole, full to the brim with water $\langle\ldots\rangle$. The rider's heart did not bear the frantic chase, and Lukash had died a moment before the horse's hoofs touched the water"; Mykolai, riding to intercept his friend, "was half beheaded by a willow branch, hanging over the bog" ${ }^{25}$. In Yu. Vynnychuk's novel there is also a correlation of the Beautiful Lady character named Liutetsia with the

${ }^{53}$ Keats J. La Belle Dame Sans Merci. URL: https://www.poetryfoundation.org/poems/ 44475/la-belle-dame-sans-merci-a-ballad. (Accessed: 31.07.2016).

${ }^{54}$ Винничук Ю. Лютеція. С. 271.

${ }_{56}^{5}$ Monaghan P. The Encyclopaedia of Celtic Mythology and Folklore. P. 52.

${ }^{56}$ Пагутяк Г. Зачаровані музиканти. С. 149. 
bog topos. It is important to underline the fact that Liutetsia was the name of the ancient settlement of the Celtic tribe located in the place of the modern Paris. The origin of this name has not been clarified for certain but it could have derived from the Celtic word "luteuo" meaning "bog".

Thus, the correlation of the mythologem of the fairy lover with the motif of death has much in common in I. Murdoch's and H. Pahutiak's novels, since many mysterious deaths relate to the female characters embodying La Belle Dame sans Merci. Yu. Vynnychuk's interpretation of this correlation is different because the character representing the mythologem of the fairy lover - Liutetsiia - could be a potential victim of murdering.

\section{The topos of fairyland and the motif of fairy music interpreted by I. Murdoch, H. Pahutiak and Yu. Vynnychuk}

The embodiment of the mythologem of fairyland in the novel "The Unicorn" is Gaze Castle where Hannah Crean-Smith and her "jailers" live, in "The Enchanted Musicians" this topos is represented by the Country over Danube, where the Prince and Princess of Those living underground and flying in the air reign, in "Liutetsiia" it is visualized in the oneiric space, emerging in the narrator's visions. Interpreting this Celtic mythologem, the writers actualize the chronotope of parallel worlds. The attribute of fairyland - the land of otherworld beings - which was a remote beautiful place on a floating island in the ocean, beneath grassy mounds, on wet bogs or floating in the air $^{57}$, is a different time dimension: "an evening passed at a fairy dance might be the equivalent of centuries of human time ${ }^{58}$. In I. Murdoch's version the topos of fairyland acquires distinct gothic features, accentuated by S. Pavlychko: "The gothic house of Hannah Crean-Smith on the background of appalling landscapes (from one side - the ominous, cold sea, from the other side - impassable bogs, radiating green light at night), and the dismal atmosphere of mysteries and horrors, and weird people living in the house - all this reminds of the traditions of gothic novels. <... "The Unicorn" belongs to those works of the author where demonic passions swirl, and the images are saturated with black symbolism"59. Coming to Gaze Castle, situated at the seaside ("the remote and reputedly beautiful region"60), Marian Tailor immediately

\footnotetext{
${ }^{57}$ Monaghan P. The Encyclopaedia of Celtic Mythology and Folklore. P. 174.

${ }^{58}$ Monaghan P. The Encyclopaedia of Celtic Mythology and Folklore. P. 179.

59 Павличко С. Лабіринти мислення : інтелектуальний роман сучасної Великої Британії. С. 297.

${ }^{60}$ Murdoch I. The Unicorn. P. 10.
} 
noticed its difference from the reality familiar to her and realized "the beginning of something quite new" ${ }^{\prime 61}$. After an unsuccessful attempt to kidnap Hannah, to take her away from the castle and break the spell, it seemed to the girl that "many years have passed in two days" ". Effingham also felt the existence of several realities, watching the people who lived beyond Gaze Castle: "They did not belong to the world, to the time from which he had just emerged"63. Jamesie Evercreech had macabre notions about the dwellers of the castle: "All the people round here are related to the fairies" ${ }^{64}$. Marian Tailor thought that fairy blood flew in Denis Nolan's veins, who was considered one of invisible creatures by Jamesie: "We call him the invisible man" ${ }^{\text {" } 5}$. Gerald Scottow also appeared rather mysterious to Marian: "So he too had fairy blood!"66. Mrs. Crean-Smith seemed to her a youngish and beautiful and spiritual-looking in a rather fey way"67. Effingham felt that miss Tailor was "a frail elf, a little ghost that ran away squeaking and gibbering when the day-light came"68 and that he "had dabbled in necromancy, he held communion with the dark powers"69. According to the Celtic mythology there were gates or entrances between the worlds ${ }^{70}$. This mythological feature is stressed in Pip's words addressed to Hannaha: "Come out through the gates into the real world"71.

In I. Murdoch's novel the character of "the prisoner" Hannah is ambivalent, because it combines the semantics of a victim and a mistress: "She spoke as a queen, one who highly disposes of herself" specific features of the character manifest themselves in Marian's reflections: "It was Hannah's authority which had moved her, her sense, in the pathetic scene of her final imprisonment, of Hannah's sovereignty, of her royal right to dispose of herself as she would", ${ }^{\text {, Effingham Cooper }}$ called Hannah a princess, his friend Elizabeth also used this "title" talking about Mrs. Crean-Smith.

\footnotetext{
${ }^{61}$ Murdoch I. The Unicorn. P. 29.

${ }^{62}$ Murdoch I. The Unicorn. P. 214.

${ }^{63}$ Murdoch I. The Unicorn. P. 192.

${ }^{64}$ Murdoch I. The Unicorn. P. 44.

${ }^{65}$ Murdoch I. The Unicorn. P. 45.

${ }^{66}$ Murdoch I. The Unicorn. P. 47.

${ }^{67}$ Murdoch I. The Unicorn. P. 27.

${ }^{68}$ Murdoch I. The Unicorn. P. 193.

${ }^{69}$ Murdoch I. The Unicorn. P. 193.

${ }^{70}$ Monaghan P. The Encyclopaedia of Celtic Mythology and Folklore. P. 174.

${ }^{71}$ Murdoch I. The Unicorn. P. 223.

${ }^{72}$ Murdoch I. The Unicorn. P. 223.

${ }^{73}$ Murdoch I. The Unicorn. P. 247.
} 
Dokiia, who spent a year in the Country over Danube, felt its peculiarities: "It was not a year, but seven years, because time passes differently among Those living underground and flying in the air" ${ }^{74}$. After she came back to the world of humans she "wanted to retain the feeling of the space and time of that wonderful world" otherworld reality is also realized by other characters of "The Enchanted Musicians": in Mykolai's oppinion, Oleksander Domnytskyi "lived in our and the other world at the same time" "76. In H. Pahutiak's book "Urizh and its spirits" there is special concordance of the semantics of the Country over Danube topos and the mythologem of fairyland: it is a land "where there are no sorrows and grieves $<\ldots>$. There are musicians riding beautiful flying horses, there is an eternal festival, similar to that one on the island Avalon" ${ }^{, 77}$. The mythological fairyland was a monarchy, ruled by a beautiful fairy queen ${ }^{78}$. In H. Pahutiak's version the Country over Danube was governed by the Prince and Princess of Those living underground and flying in the air. However, the Princess was considered more powerful and mighty: one of the musicians underlined that when speaking to Matvii: "Do you know that we serve the Princess and that she is more important for us than the Prince?"79. It was the court of the Princess and not that of the Prince, where the spirits of earth, air, water and trees met once a year.

In Yu. Vynnuchuk's novel the topos of fairyland is not represented vividly though the female character is associated with a monarch: it seemed to Vahylevych that he spoke to "an enchanted queen who knows her mystery and has no right to betray it" ${ }^{\prime 80}$. As in I. Murdoch's and H. Pahutiak's novels, the space in "Liutetsiia" has many defining characteristics of Gothic literature. For instance, a macabre building arises in Vahylevych's dreams: "Grey, unpleasant, with pointed towers, with shabby plaster, with grinning red gums of bricks, with rich splashes of evergreen colour, shining in the light of the Moon, it evoked cemetery memories, turning the house into a sort of crypt" ${ }^{\prime \prime 1}$.

\footnotetext{
${ }^{74}$ Пагутяк Г. Зачаровані музиканти. С. 137.

75 Пагутяк Г. Зачаровані музиканти. С. 149.

${ }^{76}$ Пагутяк Г. Зачаровані музиканти. С. 56.

77 Пагутяк Г. Уріж та його духи. С. 56-57.

${ }^{78}$ Monaghan P. The Encyclopaedia of Celtic Mythology and Folklore. P. 177.

${ }^{79}$ Пагутяк Г. Зачаровані музиканти. С. 208.

${ }^{80}$ Винничук Ю. Лютеція. С. 99.

${ }^{81}$ Винничук Ю. Лютеція. С. 230.
} 
Fairies "were renowned for their love of music" 82 . Almost nobody could resist their haunting melodies, the hypnotizing rhythm of which was distinctive from the music of mortals. The favourite instruments of fairies were the pipe and the harp ${ }^{83}$. A mystic melody can be considered an attribute of the fairy land in "The Unicorn": in Gaze Castle "there was a sort of dragging music barely heard" 84 . "One of the invisible beings" Denis Nolan - had a gift of playing the piano and singing. The atmosphere of mysteriousness dominates in I. Murdoch's depicting the scene of the musical party in her novel: "The sound filled and honey-combed the collected room, making the rapt audience one with itself, a great golden object rising slowly through space" ${ }^{95}$. When Denis was singing the song, it seemed "as if the audience were sitting forward in their chairs ready to participate in some marvelous transfiguration. Yet Denis himself seemed by now almost invisible, so much had he made sound sovereign over vision" $" 86$.

The motif of fairy music is the major one in H. Pahutiak's novel and it is more distinctive than in I. Murdoch's "The Unicorn". It starts to evolve at the beginning of the narration: "heavenly" music is a part of the "wild wedding", watched by Matvii Domnytskyi. He had not played musical instruments before he met the Lady with fire-red hair, but then he was given the gift to play music: "His hands started spinning on their own, and the strap of the tambourine adhered to his neck. And it was all without efforts, so easily, as if Matvii had had a tambourine in his cradle and struck it with his feet" ${ }^{\prime 7}$. Music in the novel is endowed with a powerful force, and the young Domnytskyi felt its effect on himself: "And it managed to change him irreversibly, associating with the image of the Lady accompanied by this music" $"$. The pipe was one of the instruments of the enchanted musicians taking part in the "wild wedding". Another character of the novel, Nastia, saved from being lost in the forest by "the Lady, dressed like a queen", told Osyp that "where there was a bog, she heard music and singing" " the context of our research: "In the fairy novel "The Enchanted Musicians" music there is a significative and structurizing center, and the

\footnotetext{
${ }^{82}$ Monaghan P. The Encyclopaedia of Celtic Mythology and Folklore. P. 176.

${ }^{83}$ Monaghan P. The Encyclopaedia of Celtic Mythology and Folklore. P. 176.

${ }^{84}$ Murdoch I. The Unicorn. P. 29.

${ }^{85}$ Murdoch I. The Unicorn. P. 137.

${ }^{86}$ Murdoch I. The Unicorn. P. 137.

${ }^{87}$ Пагутяк Г. Зачаровані музиканти. С. 110.

${ }^{88}$ Пагутяк Г. Зачаровані музиканти. С. 86.

${ }^{89}$ Пагутяк Г. Зачаровані музиканти. С. 74.
} 
corresponding concept arises in the interpretations close to the ideas of the Ancient East and Classical Greek philosophies, and also the Celtic and Ukrainian mythical thinking" "90.

In Yu. Vynnychuk's novel the motif of love for the Beautiful Lady similarly correlates with the motif of music. In his dream the narrator found himself in a mysterious house where, coming in under the door, "there was a strange music, far from being melodious, but rather ritual, with roaring and muffled beating. $<\ldots>$ the music frightened and did not predict anything good" ". In such gloomy atmosphere "a tall graceful lady with her fire-red hair down"92 appeared. It is necessary to stress that the motif of music is immediately related to Liutatsia character, because she was a singer: "a few musicians at the end of the hall played something melancholic. Liutetsia stood up and went to the stage, and in a minute she caught up the melody with her deep soft voice, fascinating the listeners, made them sit still and screw up their eyes"93. The narrator found Vahylevych's notes about his dreams describing his wandering in the town where he "entered a mysterious tavern, which he had not seen at that place before. He was attracted by light and music. In the tavern there were a lot of people, their eyes were turned to the stage, where the girl with gingerred hair was singing" 94 .

Thus, the spatial images, representing the topos of fairyland, are visualized more vividly in the novels of the women-writers, whereas Yu. Vynnychuk only outlined the oneiric space associated with this mythologem. However, all the three female characters in the authors' works correlate with the figure of the fairy queen, ruling the fairyland in the Celtic mythology. The motif of fairy music evolves most evidently in H. Pahutiak's novel, and it can be considered a minor one in "The Unicorn". The allusive connection of Liutetsiia character with the motif of fairy music is quite obvious in Yu. Vynnychuk's work.

\section{CONCLUSIONS}

The genesis of the female characters and major motifs in the novels "The Unicorn" by I. Murdoch, "The Enchanted Musicians" by H. Pahutiak

90 Чухонцева Н. Семіосфера концепту «музика» в романах Галини Пагутяк. Науковий вісник Херсонського державного університету. Серія «Лінгвістика». Вип. 28. Херсон : ХДУ, 2017. С. 114.

${ }^{91}$ Винничук Ю. Лютеція. С. 53.

${ }^{92}$ Винничук Ю. Лютеція. С. 53.

${ }^{93}$ Винничук Ю. Лютеція. С. 56.

${ }^{94}$ Винничук Ю. Лютеція. С. 57. 
and "Liutetsiia" by Yu. Vynnychuk is certainly related to the Celtic myth of the fairy lover interpreted by the writers following the traditions of Gothic literature. The most distinct typological parallels in the writers' novels are traced in visualizing the appearances of the fairy lover characters (the Niamh of the Golden Hair) - Hannah Crean-Smith, the Lady with fire-red hair and Liutetsiia (ravishing beauty, red hair, clothes of green colour), and also in the correlation of the female characters with the motifs of kidnapping (stolen men and women lose their will and become dependent on their passion for fairy creatures), fairy music (the melodies

played in the fairyland have a magic power over humans) and death (in each of the novels there are victims, and all the deaths are mysterious and enigmatic) and also the allusions to John Keats' ballade "La Belle Dame sans Merci". Additionally, the resemblances are evident in using the neomythological technique of deheroization of the knight character (the men who devote themselves to serving the Beautiful Lady, are not ready to struggle for her), in the atmosphere of fatal mystery dominating in the novels (appalling landscapes and gloomy buildings inhabited by strange people), in the relation of the tragic modus with the bog topos (it is associated with either death itself or being on the verge of it). Unlike the versions of I. Murdoch and H. Pahutiaak, Yu. Vynnychuk's interpretation of the figure of the fairy lover is notable for its oneiric nature: the Beautiful Lady with red hair mostly appears in the male characters' dreams. It provokes allusions to G. G. Marques "Eyes of a Blue Dog". These findings can be useful for further research on similar topics, in particular, on the interpretation of the Celtic mythology in contemporary fiction.

\section{SUMMARY}

The study examines the specificity of adopting and incorporating the Celtic myth of the fairy lover in the novels "The Unicorn" by I. Murdoch, "The Enchanted Musicians" by H. Pahutiak and "Liutetsia" by $\mathrm{Yu}$. Vynnychuk. It mainly focuses on the visualization of the mythical Niamh of the Golden Hair in the writers' works, accentuating her distinctive features in the characters of Hannah Crean-Smith, the Princess of Those living underground and flying in the air and Liutetsiia. The study looks at the correlation of the female characters with the motifs of fairy kidnapping, fairyland and fairy music. The paper also highlights the features of La Belle Dame sans Merci in the literary projections of the fairy lover and the gothic arrangement of the characters. In addition, it stresses the role of the bog topos in generating appalling atmosphere of the three novels. The research made it possible to find out typological parallels in the literary prose of I. Murdoch, H. Pahutiak and Yu. Vynnychuk and also 
identify the specific features which allow drawing a conclusion about original interpretations of the Celtic mythologem of the fairy lover by the Irish and Ukrainian writes. These findings can be useful for further research on similar topics, in particular, on the interpretation of the Celtic mythology in contemporary fiction.

\section{REFERENCES}

1. Букіна Н. «Готика» в романі «Зачаровані музиканти» Галини Пагутяк під кутом зору гендерних інтерпретацій. Наукові пращі. Літературознавство. 2014. Вип. 219. Т. 231. С. 24-28.

2. Букіна Н. Типологія родинного прокляття та помсти в романі «Зачаровані музиканти» Галини Пагутяк. Слово $i$ час. 2013. № 6. C. 93-97.

3. Винничук Ю. Лютеція. Харків : Фоліо, 2017. 365 с.

4. Качуровський I. Острів фантастів (Ірляндія та іï роля у збереженні культури). Генерика i архітектоніка. Київ : Видавничий дім «Києво-Могилянська академія», 2005. С. 39-50.

5. Павличко С. Лабіринти мислення: інтелектуальний роман сучасної Великої Британії. Зарубіжна література: дослідж. та критич. статті. Київ : Вид-во Соломії Павличко «Основи», 2001. C. 271-389.

6. Пагутяк Г. Зачаровані музиканти. Київ : Ярославів Вал, 2010. $224 \mathrm{c}$.

7. Пагутяк Г. Панна з жовтим волоссям. Потонулі в снігах. Львів : ЛА «Піраміда», 2010. С. 59.

8. Пагутяк Г. Сентиментальні мандрівки Галичиною. Львів : ЛА «Піраміда», 2014. 192 с.

9. Пагутяк Г. Уріж та його духи. Львів : ЛА «Піраміда», 2012. $120 \mathrm{c}$.

10. Родик К. Ребрендинг містифікатора: рецензія на «Лютецію» Юрія Винничука. URL: https://umoloda.kyiv.ua/number/ 3289/164/121666/ (Accessed: 31.07.2019).

11. Романенко О. Семантичне дзеркало сну в українській високій $\mathrm{i}$ масовій літературі. Вісник Київського національного університету імені Тараса Шевченка. Літературознавство, мовознавство, фольклористика. 2012. Вип. 23. С. 16-21.

12. Чухонцева Н. Семіосфера концепту «музика» в романах Галини Пагутяк. Науковий вісник Херсонського державного університету. Серія «Лінгвістика». Вип. 28. Херсон : ХДУ, 2017. C. 110-115. 
13. Jarząb J. The Significance of Space in Iris Murdoch's "The Unicorn" as a Twentieth-Century Irish Gothic Novel. Studia Anglica Posnaniensia. Issue 49/4. 2014. P. 5-20.

14. Keats J. La Belle Dame Sans Merci. URL: https://www.poetryfoundation.org/poems/44475/la-belle-dame-sans-mercia-ballad. (Accessed: 31.07.2016).

15. Monaghan P. The Encyclopedia of Celtic Mythology and Folklore. New York: Facts on File, 2004. 512 p.

16. Murdoch A. The Unicorn. London: Triad/Granada, 1982. 272 p.

17. Nejad S. F. Intertextuality and Parody in Iris Murdoch's "The Unicorn". International Journal of English Research. Volume 3. Issue2. 2017. P. 87-93.

Information about the author:

Bokshan H. I.

Candidate of Philological Sciences, Associate Professor at the Department of Foreign Languages, Kherson State Agrarian University 23, Stritenska str., Kherson, 73009, Ukraine 


\section{STRATEGIES OF MYTH-MAKING IN THE HISTORICAL AND PHILOSOPHICAL DISCOURSE OF THE NOVEL "THE WANDERING JEW" BY S. HEYM}

\section{Ilinska N. I.}

\section{INTRODUCTION}

The idea that, "since the twentieth century, myth begins to occupy a privileged place in the culture, and mythological consciousness turns out to be a significant component of historical, ideological, and artistic consciousness", is the topos of modern. There is a huge number of literature works on the mythocentric trends of our time. The works devoted to the problems of the interaction of myth and literature, myth and history (P. Ricoeur, J.-F. Lyotard, R. Bart, J. Droysen, L. Hutchen, E. Wesseling, A. Compagnon, T. Bovsunivska, V. Malkina) are especially important for our research in the aspects of mythologization, myth-making and demythologization of literary texts. In the literature of the late $20^{\text {th }}$ and early $21^{\text {st }}$ centuries, these phenomena become links in one process, which is vividly presented in the novel "The Wandering Jew" (1981) by German writer Stefan Heym (1913-2001).

A few words about the title category of the work. The term "strategy", relevant to modern literary criticism, in the Penguin Dictionary of Literary Terms And Literary Theory is defined as "either an author's attitude towards his theme and subject, or his method or technique", Referring to the basic definition, we understand the strategies of myth-making as different ways of author's interpretation of a myth ("theme") and its artistic embodiment ("method or technique") in various parameters: from 1) using its structural and semantic elements without modification to organize the narration to 2) author's transformations of traditional mythologies for modeling a new artistic reality.

In our study, by discourse we mean verbal communication, the subject of which is views on a common problem: myth-making and historical fact

1 Хренов Н. А. От эпохи бессознательно мифотворчества к эпохе рефлексии о мифе // Миф и художественное сознание XX века /Ред. Н.А. Хренов; Гос.ин-т искусствознания. М.: Канон-плюс, 2011.С..79

2 The Penguin Dictionary of Literary Terms And Literary Theory / ed. J. Cuddon (revised by E. Preston). London: Penguin books, 1998. R. 276 
in the postmodern poetry of a literary text. The aim of our study is to consider myth-making strategies as genre-forming ones in the historical and philosophical discourse of the novel "The Wandering Jew" by Stefan Heym.

Actuality and degree of coverage of the problem. S. Heym's novel is insufficiently studied. Only several articles (G. Ishimbaeva, T. Vilisova, E. Boriseeva) and dissertations (N. Polishchuk, H-P. Ecker) are devoted to it. The analysis of literary sources allows us to identify scientific gaps, the filling of which determine the actuality and novelty of our work. We will analyze these sources from this point of view.

Thus, in the article "Historical novels "The King David Report", "The Wandering Jew" by Stefan Heym: of history and historical reflection" by T. Vilisova, the historical problems of the novel "The Wandering Jew" by Stefan Heym are considered. According to the author of the article, "the story in the novel is presented fragmentary: the creation of the Earth and man, the beginning of a new reckoning after the advent of Christ, his life and death, Germany after the Reformation, the $80-\mathrm{s}$ of the $20^{\text {th }}$ century in the GDR and Judgment day". The writer's attention is focused on showing the personality in the context of history, which allows the reader to personally recognize its movement. The issues of historical responsibility, which correlate with modern events in connection with changes in the axiological orientations of society, are especially acute. The article focuses on the functions of the mythological elements of the work, which form the semantic horizon of the novel and are the "key" to its understanding. According to the researcher, "the myth for S. Heym is a constant that allows to order dissimilar material (legend, religion, science) and organize it into a single text"3 Agreeing with this thesis, we emphasize that S. Heym's appeal to biblical history and apocrypha in the novel "The Wandering Jew" has primarily a metaphysical meaning. The writer creates an artistic reality in which a different mythopoetic picture of the world is presented. This aspect is noted by N.-P. Ecker who is the author of the dissertation on "The Wandering Jew". He believes that the history of mankind in S. Heym's novel is presented "as an episode of a more global structure - the cosmos". Indeed, the cosmism of the writer's worldview encompasses two key events in biblical history - the creation of the world

3 Вилисова Т. Исторические романы Стефана Гейма «Книга царя Давида», «Агасфер» : демифологизация истории и историческая рефлексия / https://philologicalstudies.org/dokumenti/2006/vol1/22.pdf

${ }^{4}$ Ecker H.-P. Poetisierung als Kritik. Stefan Heyms Neugestaltung der Erzählung vom Ewigen Juden. Tübingen: Narr, 1987 s. 91. 
and Armagedon. Apparently, from the point of view of Eternity, nontraditional assessments of character images - Jesus, Ahasuerus, Leuchtentrager (Lucifer), historical figures - Martin Luther, Philip Melanchthon, Paul von Eitzen, Lucas Cranach, were submitted by the myth-maker. One of the priority tasks of our study is to consider mythmaking strategies in the historical and philosophical line of the novel "The Wandering Jew" by Stefan Heym.

In E. Boriseeva's review article "The mythologem of Ahasuerus in the literature of post-modern epoch"5, S. Heym's novel is mentioned among others presented in the foreign literature of the $20^{\text {th }}$ and $21^{\text {st }}$ centuries. The author of the article sees the reason for the popularity of the migratory in the differentness and incompleteness of the of Ahasuerus in any culture, but the "eternal image" acquires a new life precisely in the dialogue of two consciousnesses - Us-Them. It has been rightly noted that in the process of transformation mythologem, the of Ahasuerus withdraws from pretext, the legendary image "acquires" new meanings, depending on contexts and author's intentions. Indeed, the image of the Eternal Wanderer in $\mathrm{S}$. Heym's novel is significantly different both from the legendary pretext and from the literary tradition. One of the further strategies of our research is to clarify the specifics of the secondary mythologization of the image of Ahasuerus in S. Heym's artistic consciousness.

In N. Polishchuk's dissertation "Transformation of Ahasuerus' mythologem in West European literature of the 19-20 centuries" image of the Wandering Jew is considered in a transhistorical context: from proto-text - the medieval legend of a man who insulted God, to the post-modern version of the mythologem of Ahasuerus in the novel by S. Heym. The author considers the ethno-specificity of this mythologem, comparing the invariant of the European legend about the Wandering Jew with the image of Marko Prokliatyi (Damned Marko) from the eponymously-named novel by O. Storozhenko (1806-1874). It has been marked the national component of the mythologem of Ahasuerus, that symbolizes "the scattering and foreignness of the Jews themselves around the world, which seems to be the realization of Ahasuerus' terrible curse on eternal".

5 Борисеева Е.А. Мифологема Агасфера в литературе эпохи постмодерна / http://elib.bsu. by/handle/123456789/36674

6 Поліщук Н. Трансформація міфологеми Агасвера в західноєвропейській літературі XIX - XX ст. Автореф. дис... канд. філол. наук: 10.01 .04 / Львів. нац. ун-т ім. I. Франка. - Л., 2001. 
Comparing the transformations of the mythologem of the Wandering Jew in the cultural and historical paradigms of the Romantic and postmodernism, N. Polishchuk identifies two models: the canonical paradigm of and the controversial paradigm of postmodernism. The dissertation examines the ambivalence and "diversity" of the post-modern version of Ahasuerus' mythologem. However, the use of "author's" terminology without necessary explanations, for example, the "polyapocryphal nature of Ahasuerus' mythologem", "the game aspect of the creation of meta-apocrypha" darkens the meaning of these interesting aspects of the study.

A study of literary sources devoted to S. Heym's novel "The Wandering Jew" allows us to determine and correct the vectors of our study.

\section{Multi-genre nature and myth-making: points of intersection}

As the analysis shows the genre structure of S. Heym's work "The Wandering Jew" in the context of author's myth-making is the least studied. And it is no coincidence, unsteady boundaries of the genre in nonclassical aesthetics give rise to thoughts of its disappearance (B. Croce, J. Derrida). To T. Bovsunivska's mind “... most researchers consider the category of the genre so old-fashioned that they do not use it at all, and the rest offer their own interpretation, which is so different from Aristotle's traditional times, that rather prevents the understanding and perception of a literary work than helps to clarify its artistic nature. The age of postmodernism shook the omnipotence of the genre" "7. In the literature of the $20^{\text {th }}$ century there are new forms of literary works that are characterized by genre diffusion (terminological synonyms - multi-genre nature, genre polyphony, genre shift, genre convergence).

Literary critics noticed the tendency of postmodern writers to decanonize and synthesize genres that is also observed in the novel "The Wandering Jew" by S. Heym. Mythologizing strategies, trends, complexes of dominant myths, processes of transformations and creations of new models, coupled with the dynamics of spiritual and aesthetic search, determine the multi-genre nature of S. Heym's novel "The Wandering Jew". Its multi-level structure covers the genre elements of a historicalphilosophical novel, a religious-historical novel, a myth / anti-myth novel, an apocryphal novel. The boundaries between these genre structures are

${ }^{7}$ Бовсунівська Т. В. Теорія літературних жанрів : Жанрова парадигма сучасного зарубіжного роману : Підручник / К.: Видавничо-поліграфічний центр «Київський університет», 2009. С. 64. 
easily pervious and open (S. Averintsev's term). The writer reinterprets the Sacred History, historical facts and personalities of German culture of the distant and recent past, referring to the concepts and poetics of postmodernism.

\section{Genre invariant of a historical novel in S. Heym's modification}

The genre dominant of S. Heym's novel "The Wandering Jew" is a historical and philosophical discourse, the specificity of which allows us to argue that the author created a new type of historical novel. To prove this, let us turn to the invariant model of the genre described by V. Malkina, a comparison with which will demonstrate the author's modifications from the point of view of the influence / not influence of the concepts and attitudes of postmodernism on it. In other words, it remains to be clarified what traditions of the historical novel S. Heym inherits, what is the essence of his innovations and how myth-making strategies are involved in the creation of a postmodern genre form of the historical novel.

According to V. Malkina, an invariant of a historical novel, i.e. a set of stable features and characteristics which are typical for the works of this genre, regardless of the time and place of their writing, includes such parameters. The main feature of the historical novel is the combination of historicism and "Gothic anthropologism". Among the many definitions of historicism, she accepts M.I. Steblin-Kamensky's "hypothesis of nonidentity". The essence of the hypothesis is "the assumption that the psychology of medieval man is not identical with the psychology of modern man. That is, historicism appears when the differences in human psychology are realized".

The following feature of the historical novel invariant can be traced in the speech (narrative) structure of the work. It implies "a combination of points of view of different eras" and "the presence of historical information" as a special compositional-speech form. At the level of the plot organization, the historical novel is characterized by adventurism, the ordeals of the hero, "the combination of the themes of "war and love", and all this against a background of a crisis historical era. The character system of the historical novel traces "the connection of fate and the position of the protagonist with a changing historical situation"; the presence of antagonist characters $^{8}$. We will consider these parameters in relation to S. Heym's novel "The Wandering Jew".

\footnotetext{
${ }^{8}$ Малкина В.Я. Поэтика исторического романа. Проблема инварианта и типология жанра: на материале русской литературы XIX - начала XX века : диссерт. канд. филол. наук. М. 2001. С. 108.
} 
We believe that in addition to understanding the differences in human psychology (according to Steblin-Kamensky), the concept of historical development, the philosophy of history by its author as a manifestation of historicism is an important component of the genre attribution of a historical novel ${ }^{9}$. There is every reason to state its presence in S. Heym's work. It is indisputable for a writer to believe that absolute truth is impossible, that truth consists of many subjective perceptions. He considers official and generally accepted history as a mythopoeic variant created as a result of information "filtering": what we know is only the tip of the iceberg ${ }^{10}$. It is obviously, that the basis of author's concept of history is post-modern understanding of it as a "big narrative" - history is what they write about it, and therefore it differs little from literature.

The crisis of confidence in meta-stories as a characteristic feature of postmodernism and its culture was first formulated in the work "Postmodernist destiny" ("La condition postmoderne") by J.-F. Lyotard. In Russian translation this work is known under the heading «Состояние постмодерна». According to the French philosopher, in a postmodern situation, the metanarratives have lost their "legitimizing" function of substantiation of the laws, moral norms and structures of social institutions ${ }^{11}$. Researchers argue that even non-configurational texts are not free from the subjective view of the historian and the appraisals inherent in modern times (см. об этом : П. Рикер, И. Дройзен) $)^{12}$. Doubts about the possibility of cognizing reality through historical knowledge and traditional philosophy give rise to "epistemological uncertainty". This state of man and society produces a need to look for other ways of comprehending being, which happens in the case of S. Heym. The writer's attempt to comprehend the movement of mankind in the "great time", in the context of relativity and distrust of explanatory systems, the desire to find support in universals continues the tradition of the German historical and mythological novel of T. Mann, G. Grass, K. Wolff.

It seems that in the historical and philosophical discourse of S. Heym's work, the specificity of the historicism of the post-modern novel is significantly manifested. On the one hand, the writer creates a purely

9 Соколянский М.Г. Историзм. Литературоведческие термины: Материалы к словарю. Коломна, 1999. С. 37-40.

10 Вилисова Т. Исторические романы Стефана Гейма «Книга царя Давида», «Агасфер»: демифологизация истории и историческая рефлексия / https://philologicalstudies.org/dokumenti/2006/vol1/22.pdf

${ }_{11}$ Лиотар Ж.-Ф. Состояние постмодерна. - Спб.: Алетейя, 1998. С. 7.

12 Дройзен, И. Г. Историка . СПб.: Владимир Даль, 2004. С.70, С.155 ; Рикёр, П. Время и рассказ. Т. 1 М., СПб.: Университетская книга, 1998. С. 204. 
historical novel, events in which can occur only in the described historical era - during the Reformation or democratic Germany, which determines the characters, actions and psychology of the heroes. On the other hand, the author appeals to the present and tests for strength, it would seem, unshakable truths and authorities, so that, to create his own myth based on universal mythological structures and personal experience of historical reality. Based on documented historical facts, the postmodern writer reserves the sacred right of the demiurge to freedom of interpretation and assessment of historical events and personalities, to rewrite historical myths and their characters.

The strategies of demythologization and "rewriting" of history are especially vividly shown in chapters devoted to Martin Luther (14831546), the German theologian who laid the foundation of the Protestant Reformation. Since he is not the protagonist of the work, this image remained almost unnoticed in a few publications devoted to the analysis of the novel. However, the debate about Luther and his teachings is latently present on the pages of the novel from beginning to end, making up his ideomyth based on the historical and philosophical reflection of the author. It seems that one of the mythological structures - the mythologem of the cultural hero - can serve as an interpretative model of the image of Martin Luther.

As it is known, the mythologem of the cultural hero embodies the ideas of harmony and order, which are consistently implemented in the movement from chaos to space. In modern culture, its semantics goes far beyond the boundaries of myth, encompassing the heroes of the epic, historical and religious figures. However, at the same time, the invariant basis is preserved - the activity of the cultural hero is assessed as constructive from the position of Eternity, on condition that it has a positive meaning for the regulation of being. It is quite natural that a personality of such a scale as M. Luther, who caused controversy during his lifetime, is surrounded by mythology in its historical existence. For the history of mankind, which exists as a metanarrative according to F. Lyotard, is not so important, if Luther actually nailed a poster to the church gate in Wittenberg or sent out his 95 theses as a document ${ }^{13}$; whether or not he threw an inkwell at the devil - all the more several places argue about their involvement in this event; during a storm or

${ }^{13}$ Brendler, G. Martin Luther. Theologie und Revolution. VEB Deutscher Verlag der Wissenschaften, Berlin, 1983. S. 107 
thunderstorm he took the oath of monasticism ${ }^{14}$ There is no doubt that we live in a world created by the Reformation. It is one of the starting points of the history of the Western world with all its successes and failures. In this regard, it is difficult to deny the importance of the personality of Martin Luther's activity, but we can tell about them, "breaking the reality from one or another point of view" 15 The choice of a way to tell a story is determined by the narrative perspective, which acts as a semantic correlate between the point of view and the narrated events ${ }^{16}$. S. Heym uses several narrative instances, both explicit and implicit in creating his own myth about M. Luther. The first two include the narratives of the schoolboy Paul von Eitzen - a supporter of Dr. Martinus and a professor from Jerusalem H. Leuchtentrager - his main exposer. An implicit instance is Ahasuerus' thoughts about the world order and free will, inviting the reader from this point of view to evaluate M. Luther's personality and his religious reform activity. It is the reader whom the author opens up a wide field of free choice in answer to the question: who was Martin Luther in history "a wheel that got into a rut" or "a coachman driving a bull"? This strategy of the author's relationship with the reader in S. Heym's new historical novel differs from the position of the omniscient author in the traditional one.

The historical storyline also tells about the life of Paul von Eitzen - a real younger contemporary of Martin Luther, a student to whom he patronized. The son of cloth and wool merchant Paul von Eitzen goes to Wittenberg to study theology under the supervision of M. Luther and F. Melanchthon. At the coaching inn, he meets Hans Leuchtentrager (the meaning of the German surname Leuchtentrager is identical to the semantics of Lucifer: light-carrying, light-bringer), which becomes his companion and adviser for life. Thanks to the help of Hans Leuchtentrager (i.e. Lucifer), the lazy, not bright, but ambitious Eitzen successfully passes the exams, receives a letter of recommendation from Luther, first becomes a pastor and then a bishop.

14 Kantzenbach, F.-W. Martin Luther. Der bürgerliche Reformator. Musterschmidt, Göttingen, 1972. S. 19

${ }_{15}^{15}$ Шмид В. Нарратология М.: Языки славянской культуры, 2003. С. 9.

16 Андреева В. А. Текстовые и дискурсные параметры литературного нарратива (на материале современной немецкоязычной прозы): дис. ... д. филол. наук СПб., 2009. C. 321-22; Viehöver, W. Erzählungen im Feld der Politik, Politik durch Erzählungen. Überlegungen zur Rolle der Narrationen in den politischen Wissenschaften. Politische Narrative. Konzepte - Analysen - Forschungspraxis. F. Gadinger, S. Jarzebski, T. Yildiz (eds.). Springer, Wiesbaden, 2014. S.82. 
The provocative convergence between Luther and Lucifer in their patronage of the theological career of blockhead Eitsen is a clearly unfriendly gesture of the writer towards the father of the Reformation, if not outright sarcasm. S. Heym emphasizes such traits of the theologians Luther and Melanchthon as vainglory, the desire to make an impression that allows the demon to manipulate them: «Er (Leuchtentrager) hat Luther und Melanchthon gut studiert, sie haben nichts miteinander zu reden, aber vor Publikum versuchen sie, einander $\mathrm{zu}$ übertreffen und werden $\mathrm{zu}$ solchen Chrysostomos, dass die Zuhörer vor Bewunderung ihre Münder öffnen» ${ }^{17}$.

It is significant that the main scenes in which Luther and Melanchthon are shown are given by the eyes of Paul von Eitzen, that is, the character originally apologetic for them. The author's irony manifests itself more clearly. It evaluates, for example, their everyday behavior. So, in the episode of the general meal, the sacred feast is clearly parodied: "In der Mitte des langen Tisches saß Dr. Martinus wie Jesus Christus beim letzten Abendmahl. Seinen großen Kopf auf die Faust stützend, schaute er sich träge die Tafelrunde an ${ }^{\text {" } 18}$. The image of the doctor is deliberately reduced: for the sake of a tasty piece of meat («Er nahm sich das saftigste Stück»), he stops the theological discussion. The compromising detail is "the expression of the eyes of Dr. Martinus is both critical and satisfied" at the sight of the "playful" Leuchtentrager artifact - a coral knife in the form of a naked female figure. The author notes with irony that the great theologian "did not recognize" the devil in one of the guests of his house.

The author fixed such a feature of $\mathrm{M}$. Luther as authoritarianism and rejection of a different opinion. During the discussion, he is often annoyed, and Paul is surprised to note his intolerance and the new outbursts of anger that accompany his speech. Nietzsche afterwards calls the "garrulity of anger" Luther's manner of stringing and piling charges against his enemies. This feature is also noted in historical sources, however, unlike $\mathrm{S}$. Heym, it is evaluated in the context of the psychology of the Middle Ages. "He was a product of his time," writes Dr. Benjamin Hasselhorn, curator of the exhibition about the great reformer at his house-museum in Wittenberg, "and Luther's times were loud and rude. At that time, the inhabitants of central Germany were not polite people". But there is also other evidence in favor of humanity, generosity and the hospitality of Luther, when fifty students, pilgrims, and colleagues sat at his table. It is

17 Heym S. Ahasfer . Fischer Taschenbuch Verlag. Frankfurt / M., 1992. / https://www.dieterwunderlich.de/Heym_Ahasver.htm

${ }^{18}$ Ibid 
narrated by Martin Luther's "Table Talks" ("Tischreden"), collected by his students. It is also known that four adopted children grew up in the theologian's house (except for six of his own, four of whom survived), and during the plague his house served as a hospital and hostel for students and staff. These widely known facts from Luther's biography could not be a secret for S. Heym, who grew up in German culture. The tendentious choice of historical facts, their artistic evaluation in an ironic and parody mode, through semantic inversion, testifies to the author's intention to demythologize the image of Martin Luther as a strategy for a new historical novel.

The image of Eitzen is the mirror that reflects the influence of the personality and statements of Dr. Luther on the average person. Their convergence especially closely occurs on the basis of anti-Semitism. The anti-Semitism of the doctor is shown in the total rejection of Jewry at the level of mentality and religion. So, when Melanchthon offers to hear the story of an eyewitness Ahasuerus about the torment of Christ in order to convert Jews to Christianity, the founder of the Reformation bursts out with an angry invective against the Jews: «Christianisieren! Rief der fromme Dr. Martinus aus. - Juden? Hören Sie auf meinen guten Rat: Erstens sollten alle ihre Synagogen und Schulen verbrannt, die Messbücher weggenommen, und der Glaubensunterricht der Talmudisten und Rabbiner verboten werden. Zweitens müssen junge und starke Juden mit Ketten, Äxten und Schaufeln versorgt werden, damit sie ins Schwitzen kommen, und wenn sie nicht wollen, müssen sie zusammen mit ihrem ewigen Juden aus unserem Land vertrieben werden; Sie alle haben gegen unseren Herrn Jesus Christus gesündigt, wofür sie verflucht sind, wie der Agaspher» ${ }^{19}$.

Using the method of intertextuality, S. Heym practically quotes a documentary source - seven advice-recommendations from the pamphlet of M. Luther "On the Jews and Their Lies" (Von den Juden und ihren Lügen, 1543), which he gives to the authorities on how to behave with the Jews. In the second part of the pamphlet, Luther for the first time brings forward against the Jews an argument not of the theological, but of an economic order. He accuses them of usury, greed, dishonesty and parasitism, which finds a sympathetic response in the petty soul of Paul von Eitzen. Listening to the doctor's eloquence, he fixes contradictions and double standards, discrepancies between his words and Christ's truth, which teaches us to love our enemies. However, in reality, getting a church

19 Heym S. Ahasfer. Fischer Taschenbuch Verlag. Frankfurt / M., 1992. / https://www.dieterwunderlich.de/Heym_Ahasver.htm 
pulpit is more dependent on Dr. Martinus, "kaum zu bezweifeln, dass er recht hat." In this way, S. Heym emphasizes the destructiveness of Luther's teachings and speeches, which undermine the moral principles of Christianity. It is worth noting the realization of such a stable feature of the structure of the historical novel as the presence of ethic conflict and moral issues.

Luther's anti-Semitism is a complex and painful problem not only for the Germans, but for Christianity as a whole. However, in S. Heym's novel, it covers the other sides of the versatile, of course, ambivalent personality of a genius German, who, according to Stefan Zweig, "is overwhelmed and swelled with power and violence of a whole nation." Luther's apologists prove that his anti-Semitism has a religious basis, being a manifestation of a traditional medieval worldview. That is really true, since he did not profess racial theories that form the basis of modern anti-Semitism. Nevertheless, the fact that the Nazis used the works and the name of Martin Luther to justify the Jewish pogroms, for example, on the so-called Kristallnacht (Novemberpogrome, 1938), is widely known. As it is known, any ideology is subject to mythologization. The appeal to M. Luther as the authority of the nation allowed the politicized elite to justify their inhuman actions, giving them legitimacy, to manipulate the mass consciousness to achieve ideological goals.

So, the analysis of S. Heym's novel "The Wandering Jew" demonstrates his author's doubts about the historical viability of M. Luther as a cultural hero who created or brought to people the fruits of civilization, taught them "norms of social life and sacred rituals" and "performed various feats of world order" the reformist activities of the professor of biblical theology at Wittenberg University, considering it to be destructive and disruptive by itself. It led to an all faith schism, and then to civil war and peasant riots (1524-1525) in Germany, which M. Luther condemned, calling for the murder of rebel peasants as "rabid dogs" ("Against the Murderous, Thieving Hordes of Peasants", 1525).

It is significant that in the novel "The Wandering Jew" the constant opponent of Dr. Martinus is Hans Leuchtentrager, an angel-deity who was cast out of heaven, secret adviser to the German princes, a professor from Jerusalem, and one of the participants in the intellectual discussion. The image of the fallen angel of Lucifer inherits the world literary tradition. As

${ }^{20}$ Мелетинский Е. Культурный герой // Мифы народов мира. Энциклопедия : в 2-х т. / гл. редактор С.А. Токарев. М. 1997. Т.2. С. 25. 
it befits the spirit of doubt, he is a great tempter and provocateur. He is smart, skeptical, insightful, not devoid of charm and attractiveness, despite the outward ugliness. "Part of the strength of one without a number / Doing good, wishing evil for everything», Leuchtentrager appears in the novel as a kind of arbiter of justice. The author trusts him with the ideological plan for assessing the spiritual and religious activities of Luther, which is another marker of the demythologization of the image of the latter. Observing the crushing of human nature as a reflection of the failure of the Higher Power («Was nützen all die Alexander die Großen oder Sokrates, wenn der Himmel jetzt nicht höher als die Zimmerdecke ist?»), he sarcastically takes notice of the doctor's reformism: «Zuerst gab er dem Papst einen Tritt, aber dann erkannte er, wie notwendig er war, die göttliche Weltordnung zu bewahren, damit das Oben oben und das Unten unten bleibt ${ }^{21}$. The postmodern writer plays paradoxes, offering characters unusual roles for them: the subverter and the spirit of evil to take care of the hierarchy and harmony of the divine universe, unlike the theologian, who destructs this world order.

It is significant that the defender of the "dark" side of Dr. Martinus's activities is advocated by the director of the Institute of Scientific Atheism, Professor Siegfried Baifus, as well as his curators from the special services and the Ministry of Education. They do not care and do not need historical truth, since there is an official point of view as a monopoly on truth. «Heute erinnert dich Herr Leuchtentrager an antisemitische Äußerungen und Schreiben Luthers und morgen zitiert er das Luther-Pamphlet aus der Zeit des Bauernkrieges gegen die "mörderischen und räuberischen Rotten der Bauern", die er aufforderte zu ,zerschmeißen, würgen, stechen, heimlich und öffentlich, wer da kann, wie man einen tollen Hund erschlagen muss", was nicht nur dich, sondern alle, die an der erfolgreichen Durchführung der geplanten Feierlichkeiten arbeiten, in eine unangenehme Lage bringt» ${ }^{22}$ - socialist leaders and inspirers remind the historian of his ideology S. Baifus. In a totalitarian state, scientific objectivity depends on the political moment and submits to ideology "history is being written." Consequently, on the eve of the 500th anniversary of M. Luther, Professor Leuchtentrager becomes an undesirable person due to his remark about the influence of the hero of the day on the birth of modern anti-Semitism. The so-called "discussion" is

21 Heym S. Ahasfer. Fischer Taschenbuch Verlag. Frankfurt / M., 1992. / https://www.dieterwunderlich.de/Heym_Ahasver.htm

22 Heym S. Ahasfer. Fischer Taschenbuch Verlag. Frankfurt / M., 1992. / https://www.dieterwunderlich.de/Heym_Ahasver.htm 
closed due to the presence of only one "correct" point of view, which is contained in the ideological myth of the great German approved by the authorities.

The mirror roll call of the episodes, which unites the two "disputes" occurring at different historical times, in medieval Alton and socialist Berlin, is interesting. Their subject is the problem of reality / symbolicalness of Ahasuerus - a man who offended Christ, a witness of His Calvary sufferings, and more broadly - the problem of the existence of God and the immortality of the soul. The comparison shows: times are different, but the result is the same - the one who has power has the "truth". The paradox is that in the first case, a career that gives the right to power and a comfortable existence is ensured by the glorification of God (Paul von Eitzen), and in the second, by his atheistic denial (S. Baifus and the socialist comrades). However, in either case, they fight against dissidence - the theologian against sectarian, Baifus against ideological, thereby ensuring a comfortable life.

To reveal the mechanisms of official "historical writing", S. Heym finds an original artistic solution. The epistolary discussion between H. Leuchtentrager and S. Baifus acts as an insert genre, compositionally localized in the structure of the work ${ }^{23}$ The correspondence also plays the role of "historical reference" as a special compositional and speech form, noted by V. Malkina as an invariant of the historical novel ${ }^{24}$. Here it is worth noting such a distinctive feature of S. Heym's historical novel, as a mixture of historical sources with legendary and mythological, the inclusion of hoaxes whose purpose is to verify their historical authenticity in the reality modeled by the author. An example is a detailed selection of national versions of the legend of Ahasuerus, a Report on the trial against the adviser of the emperor Julian the Apostate from the archives of the Great Port, Qumran scroll 9 Qres, etc. The postmodern principle of nonselection used by the author blurs the boundaries between real fact and fiction, stimulates the game with the reader, and creates an ironic mode of narration.

A comparison of the genre invariant of a historical novel with a postmodern one raises the question of S. Heym's modification of such a stable feature of a historical novel as a combination of historicism and "Gothic anthropologism". Researchers (V. Zhirmunsky, I. Nabytovich,

${ }^{23}$ Іванюк Б.П. Жанрологічний словник: Лірика. - Чернівці: Рута, 2001. С. 9.

24 Малкина В.Я. Поэтика исторического романа. Проблема инварианта и типология жанра: на материале русской литературы XIX - начала XX века : диссерт. канд. филол. наук. М. 2001. С. 108. 
T. Denisova, G. Zalomkina) noted the multi-level affinity between Gothic and myth in such parameters as a picture of the world, type of consciousness and understanding of reality, which finds expression in the semantics and poetics of the work. The cogency of the Gothic component in the historical and mythological structure of the novel is evidenced by the compositional role of Lucifer-Hans Leuchtentrager as a cross-cutting character that combines sacred and profane spheres, history and modernity. A special feature of the historical novel by S. Heym is the recoding of the motives and images of the Gothic novel in a postmodern manner to create an individual author's myth.

It is most obviously represented in the Gothic motive of the contract with the devil and his invariant - selling the soul in return for certain goods. In the "Dictionary of motives and plots", it is presented the motive structure of the contract with the devil, which includes the following elements: "the hero is in dire need (in love with an inaccessible woman / seeks to get rich / get promoted / become king, etc.) - seeks the path to the devil (a specific place, time, through an intermediary) - concludes an agreement / renounces Christ - receives what he wants - realizes his own fall - after repentance (possibly through a saint) he is saved" 25 . Let us compare the invariant structure of the motive with its modification in the postmodern historical novel.

S. Heym's transformation of this motive can be traced in several aspects. First of all, the key moment of the contract that is the sale of the soul to the devil is inverted. Leuchtentrager does not need it; he initially knows the value of the human race. A rebel who did not want to bow to God's creation evaluates the soul of Paul von Eitzen no more than the usual pastor's little soul, which «davon haben wir genug, und so eine Seele bekommt man am Markttag billiger als faulen Fisch» ${ }^{26}$. Then why does the demon need all this? Probably, for the sake of a game for which the process is more important than the result.

We will call one more difference from pretext, associated with the modification of the motive for renouncing Christ. In the novel "The Wandering Jew", the author portrays Eitzen as a kind of "medieval relativist". Having successfully passed the exam, candidate Eitzen, «demnächst Magister, hat nicht vergessen, wem er alles schuldete: erstens

${ }^{25}$ Словарь-указатель сюжетов и мотивов русской литературы. Экспериментальное издание / Отв. ред. Е. К. Ромодановская. Новосибирск: Изд-во СО РАН, 2003. Вып. 1. Ред.: М. А. Бологова, Е. К. Никанорова, Е. Н. Проскурина. С. 87.

26 Heym S. Ahasfer. Fischer Taschenbuch Verlag. Frankfurt / M., 1992. / https://www.dieterwunderlich.de/Heym_Ahasver.htm 
natürlich dem Gott, von dem alle Gnade kommt, und zweitens und nicht weniger seinem Freund Leuchtentrager ${ }^{27}$. Accepting the help of the devil, he does not even think to deny the Savior. Both God and the devil safely "coexist" in his wretched little soul, because they perform the same functions - they help "to get rich / get promotion".

Moreover, because of his lack of spirituality, he does not realize the depth of the fall and does not consider himself an apostate. The doctor of theology, Eitzen, does not know the feeling of remorse. When he nevertheless has the urge to pay the bills and Ahasuerus reads him a line from the Old Testament about the punishment of evil and hypocritical shepherds, the bishop tries to save himself from the infernal flame by word juggling. Habitually resorting to a set of quotes from the Bible, he claims that «menschliche Sünden auf Gott liegen» ${ }^{28}$. However, Eitzen immediately puts himself into a trap, because in the sermons on the Divine Providence he wrote differently: «Der Fluch für den Gottlosen ist von ihm selbst vorgegeben ${ }^{29}$. The scene of "minor eschatology" was solved in a gaming way - the abduction of the soul of Eitzen, who is more frightened by the prospect of being stuck in a pipe than the flight with infernal forces.

The transformation covers other Gothic motives in S. Heym's novel. For example, the motive of a villain whose image is devoid of characteristic demonization; the motive of the dead bride, embodied in the image of Margret - the devilish spawn of rags; the motive of the birth curse - the birth of Margarita, the youngest, hunchbacked and lame, who was especially loved by her mother for known reasons.

\section{CONCLUSIONS}

Thus, in the historical and philosophical discourse of the novel "The Wandering Jew" by S. Heym, a writer of a nonconformist constitution and an opponent of any ideologies, once again denies the existence of a "right" point of view that has been unified for all times, no matter how authoritative it may seem. Turning to the documents of the era, historical facts, pamphlets and texts of the teachings of M. Luther, mythological and legendary material, using the strategies of demythologization and the techniques of postmodern poetics, the author creates his own ideological myth about the theorist-reformer. Moreover, "the data for the historical interpretation are not the realities that have not disappeared, but their trace

27 Heym S. Ahasfer . Fischer Taschenbuch Verlag. Frankfurt / M., 1992. / https://www.dieterwunderlich.de/Heym_Ahasver.htm

${ }^{28}$ Ibid

${ }^{29}$ Ibid 
in the present" ${ }^{\prime 30}$. By demythologizing the story and destroying its power status, S. Heym uses various game strategies inherent in postmodern poetics: total irony, parody, pastiche, semantic inversion, intertextuality, playing with the reader, images, game element in the narrative structures of the novel, convergence of spatial and temporal coordinates of different eras. Relying on tradition and modifying the genre forms of a historical novel, S. Heym creates his new type that is a postmodern historical novel.

\section{SUMMARY}

The article deals with the strategies of myth-making in the historical and philosophical discourse of the novel "The Wandering Jew" by S. Heym. The concepts of "myth-making strategies", "discourse", and "multi-genre nature" are being clarified. Genre modifications of the historical novel by S. Heym through its comparison with the genre invariant of the traditional historical novel have been revealed. The author's transformations of the principle of historicism, "Gothic anthropologism", the myth-making strategies in the interpretation of history have been ascertained. The historical images of Martin Luther and Paul von Eitzen, the postmodern poetics of their artistic realization have been characterized. It is proved that the main myth-making strategy is the demythologization of history as a discourse of power. The features of the genre structure of S. Heym's novel "The Wandering Jew" as a postmodern historical novel have been described.

\section{REFERENCES}

1. Андреева В. А. Текстовые и дискурсные параметры литературного нарратива (на материале современной немецкоязычной прозы): дис. ... д. филол. наук СПб., 2009. 361 с.

2. Бовсунівська Т. В. Теорія літературних жанрів : Жанрова парадигма сучасного зарубіжного роману : Підручник / К.: Видавничополіграфічний центр «Київський університет», 2009. 519 с.

3. Борисеева Е. А. Мифологема Агасфера в литературе эпохи постмодерна / http://elib.bsu. by/handle/123456789/36674

4. Вилисова Т. Исторические романы Стефана Гейма «Книга царя Давида», «Агасфер» : демифологизация истории и историческая рефлексия / https://philologicalstudies.org/dokumenti/2006/vol1/22.pdf

30 Колодинская Е.В. Историческое прошлое как предмет высказывания: современная англоязычная проза и постмодернистская историография (Г. Свифт, Дж. Барнс): Дисс. .канд. филол. наук. М., 2004. 139 с. 
5. Гейм С. Агасфер / https://bookscafe.net/book/geyms_stefanagasfer-184183.html

6. Дройзен И. Г. Историка . СПб.: Владимир Даль, 2004. 584 с.

7. Ишимбаева Г. Г. Трансформация библейского мифа в литературе постмодернизма («Агасфер» Стефана Гейма) // www.lib.csu.ru/vch/2/1997_01/019.pdf

8. Іванюк Б. П. Жанрологічний словник: Лірика. Чернівці: Рута, $2001.92 \mathrm{c}$.

9. Колодинская Е. В. Историческое прошлое как предмет высказывания: современная англоязычная проза и постмодернистская историография (Г. Свифт, Дж. Барнс): Дисс. ... канд. филол. наук. М., 2004. 139 c.

10. Лиотар Ж.-Ф. Состояние постмодерна. - Спб.: Алетейя, 1998. $160 \mathrm{c}$.

11. Малкина В. Я. Поэтика исторического романа. Проблема инварианта и типология жанра: на материале русской литературы XIX - начала XX века : дис... канд. филол. наук. М. 2001. 216 с.

12. Мелетинский Е. Культурный герой // Мифы народов мира. Энциклопедия : в 2-х т. / гл. редактор С.А. Токарев. М. 1997. Т. 2. C. 25-27.

13. Нямцу А. Е. «Бессмертный странник в человеческом мире» / К проблеме литературного функционирования легенды об Агасфере в контексте христианской аксиологии». Легендарные образы в литературе. Черновцы: «Рута», 2002. С. 127-164

14. Поліщук Н. Трансформація міфологеми Агасвера в західноєвропейській літературі XIX - XX ст. Автореф. дис... канд. філол. наук: 10.01.04 / Львів. нац. ун-т ім. І. Франка. - Л., 2001. - 20 с.

15. Рикёр П. Время и рассказ. Т. 1 М., СПб.: Университетская книга, 1998. 313 с.

16. Словарь-указатель сюжетов и мотивов русской литературы. Экспериментальное издание / Отв. ред. Е. К. Ромодановская. Новосибирск: Изд-во СО РАН, 2003. Вып. 1. Ред.: М. А. Бологова, Е. К. Никанорова, Е. Н. Проскурина. 243 с.

17. Соколянский М. Г. Историзм. Литературоведческие термины: Материалы к словарю. Коломна, 1999. С. 37-40.

18. Хренов Н. А. От эпохи бессознательно мифотворчества к эпохе рефлексии о мифе // Миф и художественное сознание XX века / Ред. Н.А. Хренов; Гос.ин-т искусствознания. М.: Канон-плюс, 2011. C. $11-82$.

19. Шмид В. Нарратология . М.: Языки славянской культуры, 2003. 312 c. 
20. The Penguin Dictionary of Literary Terms And Literary Theory / ed. J. Cuddon (revised by E. Preston). London: Penguin books, 1998. R. 276.

21. Brendler G. Martin Luther. Theologie und Revolution. VEB Deutscher Verlag der Wissenschaften, Berlin, 1983. $452 \mathrm{~s}$.

Heym S. Ahasfer . Fischer Taschenbuch Verlag. Frankfurt / M., 1992.244s./ https://www.dieterwunderlich.de/Heym_Ahasver.htm

22. Ecker H.-P. Poetisierung als Kritik. Stefan Heyms Neugestaltung der Erzählung vom Ewigen Juden. Tübingen: Narr, 1987 (Beiträge zur Sprach- und Literaturwissenschaft. Bd. 13)

23. Kantzenbach F.-W. Martin Luther. Der bürgerliche Reformator. Musterschmidt, Göttingen, 1972. 104 s.

24. The Penguin Dictionary of Literary Terms and Literary Theory / ed. J. Cuddon (revised by E. Preston). London: Penguin books, 1998. R. 276

25. Viehöver W. Erzählungen im Feld der Politik, Politik durch Erzählungen. Überlegungen zur Rolle der Narrationen in den politischen Wissenschaften. Politische Narrative. Konzepte - Analysen Forschungspraxis. F. Gadinger, S. Jarzebski, T. Yildiz (eds.). Springer, Wiesbaden, 2014. Pp. 67-91.

Information about the author: Ilinska N. I.

Doctor of Philology, Professor, Head of the Department of World Literature and Culture named after professor O. Mishukov, Kherson State University 40 rokiv Zhovtnya str., Kherson, 73000, Ukraine 


\section{MAPPING SPACE IN FICTION OF ANDREI PLATONOV}

\section{Keba O. V.}

\section{INTRODUCTION}

The specificity of space is the fundamental problem of A. Platonov's poetics. Scholars have been trying to investigate and describe correlation between real social and geographical space (as well historical time) and their fictional forms in the writer's works. Spatiality as a special category of Platonov's prose has been studied repeatedly. Plot motifs and visual images associated with space attracted the attention of literary critics, cultural experts, and philosophers: The greatest interest among works of this direction are studies of Yu. Levin ${ }^{1}$, V. Podoroga ${ }^{2}$, as well detailed comments on the Chevengur of Ye. Yablokov ${ }^{3}$. Geographical images of the novel Chevengur have been considered by D. Zamyatin ${ }^{4}$. It also seems promising to consider the spatial aspects of the writer's work in the context of the so-called "magic realism". One of the most important features of this style is a "magical space", which "although it can be quite specifically delineated, does not completely coincide with any real geographical and historical space, since the space of magical realism does not obey the generally accepted forms of determinism, but lives according to its own magical - laws..."5

The aim of the research is to identify the different aspects of spatiality in Platonov's fiction: "space of life" (the relation between the real sociohistorical space and the fictional one), and "space of text" (specific language of modeling of text and a system of relations between textual elements based on substitution of sequence in time on simultaneity in space).

1 Левин Ю. От синтаксиса к смыслу и далее («Котлован» А. Платонова). Семиотика и информатика. Вып. 30. Москва, 1990. С. 115-148.

2 Подорога В. Евнух души. Позиция чтения и мир Платонова. Параллели (Россия Восток - Запад). Альманах философской компаративистики. Вып. 2. Москва, 1991. C. 33-82.

3 Яблоков Е. А. На берегу неба (роман Андрея Платонова «Чевенгур»). Санкт.Петербург : Изд-во «Буланин», 2001. 376 с.

4 Замятин Д.Н. Империя пространства: географические образы в романе А. Платонова «Чевенгур» Филологические науки. 2000. № 1. С. 14-23.

${ }^{5}$ Гугнин А. А. Магический реализм в контексте литературы и искусства XX века: феномен и некоторые пути его осмысления. Москва, 1998.117 р. 


\section{Spatial relations in fiction}

The category of space in its relation to fiction is considered to be one of the most relevant in contemporary literary studies. Its theory was developed and formulated by Yu. Lotman ${ }^{6}$, V. Toporov ${ }^{7}$, J. Frank ${ }^{8}$ and others. Lotman distinguished two main approaches in the study of "time and space". The first is related to the Bakhtin's concept of chronotope and involves the study of forms, means and images of artistic transformation of "real" time and space in accordance with the conventions of a particular genre. The second one arises from mathematics, where space is understood as "the set of homogeneous objects (phenomena, states, facts, figures, values of variables, etc.), among which there are relations similar to ordinary spatial relations (continuity, distance, etc.). Therefore, this method requires the approach that views a text as a certain form of space and establishes connections between different elements within the architectonics of a literary text.

After Bakhtin axioms, saturated with exceptionally productive methodological potential, were regarded as the characteristics of a chronotope. They are as follows: 1) a chronotope is comprised only of that what "has become an image in a work", and that what is "created, and does not create"; 2) a chronotope, as well as the genre with which it is most closely associated, is a category of form and content; 3 ) clarification of the points of convergence of real time and space and determination of features peculiar to artistic transformation can define the specificity of a chronotope; 4) a chronotope is revealed through the connection with an image of a person in the literature of a particular period and the analysis of evolution of the genre of the novel through the prism of different types of chronotope testifies this connection.

6 Лотман Ю.М. Проблема художественного пространства в прозе Гоголя Избранные статьи. В 3-х тт. Таллин: Александра, 1993. Т. 1. С. 413-447; Лотман Ю. М. Заметки о художественном пространстве. Избранные статьи. В 3-х тт. Таллинн: Александра, 1992. Т. 1. С 448-463; Лотман Ю. М. К проблеме пространственной семиотики. Ученые записки Тартуского государственного университета. Семиотика пространства и пространство семиотки. Труды по знаковым системам XIX. Тарту, 1986. Вып. 720. С. 3-6.

7 Топоров В. Н. Пространство и текст. Текст : семантика и структура. Москва : Наука, 1983. С. 227-284.

${ }^{8}$ Frank, J. Spatial Form in Modern Literature. Critiques And Essays In Criticism. 19201948. Selected By Robert Wooster Stallman. The Ronald Press Company. New York, 1949. P. 315-328; Frank, J. The Widening Gyre: Crisis and Mastery in Modern Literature. New Brunswick, N.J. : Rutgers University Press. 1963. 278 p.; Frank, J. Spatial Form 30 years after. Spatial Form in Narrative. Ed. by J. R. Smitten and A. Daghistany. Ithaca; London : Cornell University Press, 1981. P. 202-244. 
It should be noted that Bakhtin examined literature in all the stages of its development staring from antiquity to the $19^{\text {th }}$ century inclusive, and its artistic paradigm can be called classical to a certain extent. In this literature, the axiological system of an author and characters, considering a possible complexity of the relationship between them, either had coincided or was clearly separated and understood by the reader. However, since the end of the $19^{\text {th }}$ century a growing segment of literature has been composed of works in which there is a sharp contrast between the values of an author and a character; the narrative is arranged in such a manner that it is difficult for a reader to identify the subject of speech and the latter is devoid of clarity and stability; speech discourse "drifts" from a narrator to a character, images of space and time pertaining to a character are emphatically subjective and cannot be identified as authorial ones. Thus, literature in the first half of the twentieth century certifies the artistic turn from the reproduction of the world of phenomena to the embodiment of the world of entities, and to overcoming deterministic principle of artistic thinking and a mimetic image of reality.

In modernist literature a chronotope undergoes significant changes as well. Works, in which the image of external time and space was problematic, were distributed: it (the image) either did not clearly coincide with real sociohistorical time (like Kafka), or fell out of the "objective" subject representational sphere of a story (like Proust). "External" time and space were replaced by "internal" time and space. A special type of chronotope arose - the chronotope of consciousness, which modified the organization of the principles of an artistic structuring of a work. The linear causal factor lost its structure-forming significance and gaps between text elements arose at different levels, from a story line to a subject, signifying fragmentation as the main principle of modernist narrative.

The new artistic practice required theoretical understanding, and among other methodological categories that were proposed in the first half of the twentieth century, the concept of spatial form proved to be especially productive one. It was proposed in 1945 by the abovementioned American literary critic Joseph Frank in his work "The Spatial Form in Modern Literature". Analyzing the construction of works of T. S. Eliot, E. Pound, M. Proust, J. Joyce, J. Barnes from the point of view of the specificity of their perception by the reader, J. Frank notes that "the reader is intended to apprehend their work spatially, in a moment of time, 
rather than as a sequence" $"$. Thus, the prospects of the special reception of "non-classical" literary text were in the focus of Frank's attention. First, he regarded the poetic works of Eliot and Pound in this context, and then extrapolated the receptive method of innovation comprehending of a poetic form and structure of a new novel. The realignment of the perception process from temporal to spatial is caused by fragmentation of a text, which at the level of image construction is indicated by an increase in the number of associatively linked fragments, and at the level of narrative by a violation of the chronological narrative. This structure of a work complicates the work of a reader. Frank referred to R. P. Blackmore's definition of the Elliot method as "episodic" and pointed to the separation of components of every single episode, the mixing of both verbal and figurative fragments and the constant reversal of narrative. All this required a new way of reading perception, called the "principle of reflexive reference" by Frank $^{10}$. This principle implied an active reader's interpretation of the connections between text fragments devoid of causal logic, but built on the "spatial" logic, as they did not follow each other in the process of storytelling they were connected exclusively by the spatial logic of the whole: |To be properly understood, these word-groups must be juxtaposed with one another and perceived simultaneously; only when this is clone can they be adequately understood; for while they follow one another in time, their meaning does not depend on this temporal relationship| ${ }^{11}$.

J. Frank subsequently returned to his idea in the article "Spatial Form 30 years after" and in view of the experience of formal school, "new criticism", structuralism incorporated the idea of "spatial form" into the wider context of the text theory; at the same time spatial form came to be understood as one of the possible ways of organizing a work of any era, and not just as the dominant principle of organizing a modernist text.

The increase of reader's activity in the process of text perception, the need to compare fragmented elements of the text (episodes, motives, images, text fragments), the non-linearity of reception, the ability to keep in memory certain fragments of events presented considering chronological violations, to compare different points of view, to see the connection between storylines, details, verbal and figurative constructs, intertextual

${ }^{9}$ Frank, J. Spatial Form in Modern Literature. Critiques And Essays In Criticism. 1920-1948. Selected by Robert Wooster Stallman. The Ronald Press Company. New York, 1949. P. 318.

${ }^{10}$ Ibid., p.321.

${ }^{11}$ Ibid. 
references - all this came in the twentieth century as a consequence of the complication of literary technology and brought to life the need for theoretical understanding of an open spatial structure of a text.

The formation of the spatial form was caused by the reorientation of chronotope as a mimetic time and space to the chronotope of consciousness. It is not by chance that in the characterization of modernist works one can often find such expressions as "inner time", "time of consciousness", "heme of memory", "overlay of the past and present in the space of consciousness", etc. Thirty years after J. Frank, in his adjustment of the ideas of spatial form, focused on a significant shift in the parameters of time embodiment in a literary work: "the efforts of stream-ofconsciousness writers such as Joyce, Faulkner, and Virginia Woolf to break up language itself so that it would reproduce the movements of consciousness either on the reflexive or prereflexive level. This effort to depict consciousness is what dramatizes the difference between physical and psychological time, and also calls into question the unity of the self"12.

The assertion of a chronotope of consciousness in twentieth-century literature does not abolish Bakhtin's idea: there is no impassable boundary between his chronotope and Frank's spatial form. Bakhtin always kept in sight the connection of a chronotope with an epoch and its values, and for literature of the epoch of modernism and postmodernism, such a connection should be established as well. Bakhtin wrote about a "special creative chronotope inside which this exchange between work and life occurs, and which constitutes the distinctive life of the work"13, therefore, the world of the work and the world of the author and reader are separated, but the border between them should not be understood as absolute and enduring. "However forcefully the real and the represented world resist fusion, however immutable the present of that categorical boundary line between them, they are nevertheless indissolubly tied up with each other and find themselves in continual mutual interaction; uninterrupted exchange goes on between them, similar to the uninterrupted exchange of matter between living organisms and the environment that surrounds them..."14.

Although Bakhtin did not emphasize the reader's role in the "depicting" world, but the often used phrase "a world of an author-reader"

${ }^{12}$ Frank, J. Spatial Form 30 years after. Spatial Form in Narrative. Ed. by J. R. Smitten and A. Daghistany. Ithaca; London : Cornell University Press, 1981. P. 228.

13 Бахтин М. М. Вопросы литературы и эстетики. Исследования разных лет. Москва : Художественная литература, 1975. С. 403.

${ }^{14}$ Ibid., 402. 
gives the right to say that a reader, as a co-author of the receptive creation of the artistic world, is also connected with the described process of creative interchange. It is at the intersection of the created text and each time re-created by the reader that the concept of spatial form "works". The principle of "reflexive reference" of J. Frank begins to be actualized in the space of meeting the world of a work and the world of an author and reader, when a reader constructs the content of the work from the "pieces", fragments, and compares elements of the text, builds, and draws up a definite artistic whole.

The ideas of $\mathrm{V}$. Toporov regarding the structure of a literary text are also very important. The latter is based on the fact that the text is always spacious i.e. it is a sign of space, located in real space, etc. ${ }^{15}$.

Thus, we can talk about the basic aspects of the study of artistic spatiality problems, they are such as follows: 1) spatiality is the most important property of literary works of any period; 2) artistic spatiality can be interpreted with the help of concepts of "chronotope" ("time and space in the text") and "spatial form" (text space), in the context of which spatiality is understood as a certain system of connections between text elements, on the basis of the time-sequential substitution for spatial simultaneity; 3 ) in the 20th century the predominance of spatial literary forms is connected with the orientation of a creative subject not toward physical but toward psychological time, toward the spatial consciousness of a text construction considering the possibilities of multilevel artistic communication (author - hero - reader); 4) the author's techniques that actualize a spatial organization of the work, create an effect of text fragmentation, "incomplete integrity", "sphere of uncertainty", comprehension of which requires increased reader activity; 5) clarification of a specific character of spatiality in the works with a "complicated" artistic paradigm in the literature of the 20th century creates the necessary prerequisites for an effective interpretation of their semantic versatility.

\section{Transformation of real space and time in Platonov's Universum}

It is unnecessary to prove that Platonov's work was inspired by the dramatic events of his time, which in a specific refraction occupies all the space of the writer's works. The best example of the uniqueness of the Platonov's transformation of real time and space is the novel Chevengur, a kind of author's opus magnum. The spatial and temporal organization of

15 Топоров В. Н. Пространство и текст. Текст : семантика и структура. Москва : Наука, 1983. С. 227. 
the novel is marked by obvious duality: it is, of course, a novel about Russia, about Russian people and Russian society in the era of a radical breakdown of national life; at the same time, it is a novel about human existence, about the eternal and secret, unconditional and incomprehensible in it. The story of the work takes place in a specific historical time-space on the eve of the 1917 revolution and in the post-revolutionary years. However, this fact requires reservations. The events of the "great" story are not included directly in the field of the plot action of the work, but serve only as a background for depicting the wanderings of the characters in search of "the meaning of a separate and common existence."

In Chevengur one can find many real place names associated with the territory of the Voronezh region of Russia, but the spatial and geographical specificity is very relative. In the first part of the novel, published during the writer's life as an independent work (the story The Origin of the Master), there are generally no "links" to a particular topography. In the rest of the text, there is a bizarre mixture of real and invented toponyms, and the latter clearly prevail ${ }^{16}$. The central one is, of course, Chevengur - a geographical name that, in accordance with the "strange" logic of the characters of the novel, acquires interchangeability with the abstract concept of "communism" (comp. Chepurnyi's explanation of the place from where he arrived in the provincial city: "Из коммунизма. Слыхал такой пункт? <..> Пункт есть такой - целый уездный центр. Постарому он назывался Чевенгур"17.

It is significant that Platonov makes his characters fall into spatial "confusion" very often, move in the direction opposite to what they actually need. Let us also pay attention to how and with what speed the characters of the novel overcome distances. So, Sasha Dvanov a few days after a serious wound in the leg all night runs across the steppe to the railway station, first he finds himself in a village, and then in a unfamiliar settlement, at a stand near a certain Fekla Stepanovna. Kopenkin, who is looking for him, passes all the villages that he encounters on his way one after another, checks every yard, and, surprisingly, finds Dvanov soon, although for this he probably would have taken more than one hundred kilometers and spent a lot of time. Characteristic is the very way Kopenkin travels in space; he is always "действовал без плана и маршрута, a

16 See : Ласунский О. Житель родного города. Воронеж, 1999. С. 241-250; Алейников О.Ю. На подступах к «Чевенгуру» (об одном из возможных источников названия). Филологические записки. Вып. 13. Воронеж, 1999. С. 177-184.

${ }^{17}$ Платонов А. П. Чевенгур: [Роман] / Сост., вступ. ст., коммент. Е. А. Яблокова. Москва : Высшая школа, 1991. С. 186. 
наугад и на волю коня" ${ }^{\prime 18}$. Indicative are the attempts of Zakhar Pavlovich to measure the distance to the star ("расставил руки масштабом и мысленно прикладывал этот масштаб к пространству”19) and his concern about the existence of infinity. The sign of the peculiar reversibility of space and time in the novel is a monument to the revolution, the project of which is proposed by Alexander Dvanov: "Лежачая восьмерка означает вечность времени, а стоячая двухконечная стрела - бесконечность пространства..."

The space of Chevengur, being enriched with diverse semantic connotations, is also revealed through the connection of natural and transcendental. This connection is found everywhere in the novel. It is enough to pay attention to the pictures of nature, which Platonov always saturates with metaphysics and intense psychological perception of a man: "За окном, на небе, непохожем на землю, зрели влекущие звезды. Дванов нашел Полярную звезду и подумал, сколько времени ей приходится терпеть свое существование, ему тоже надо еще долго терпеть" $\left.{ }^{21}\right)$. But even such seemingly purely everyday actions as, for example, entering a door and crossing a threshold, looking through a window (mutual transitions between open and closed spaces), are penetrated by transcendental significance ${ }^{22}$.

A particularly important place in the spatial sphere of Chevengur is occupied by motives of the road and movement. Describing the development of the road chronotope in the history of the novel, M.M. Bakhtin emphasizes that the road is "the point of tying and the place of events", it concentrates all the novel conflicts around itself, and most importantly, "the real character's path-road ... insensitively passes into the metaphor of the road, life path, soul path" 23 .

It is easy to see that the road in its literal meaning plays the main plotforming role in Platonov's novel; at the same time, the motive of the path is directly expressed in the structural and compositional organization. In fact, the whole novel is a road to Chevengur, a city that is understood by the characters as a realized idea and a space point in which the past and future cease to exist, are interchanged (see symptomatic replica of one of

${ }^{18}$ Ibid., 119.
${ }^{19}$ Ibid., 53.
${ }^{20}$ Ibid., 144.
${ }^{21}$ Ibid., $99-100$.
${ }^{22}$ See: Дмитровская М.А. Семантика пространственной границы у А. Платонова. Филологические записки: Вып.13. Воронеж, 1999. С. 118-137.

23 Бахтин М. М. Вопросы литературы и эстетики. Исследования разных лет. Москва : Художественная литература, 1975. С. 392-393. 
the characters in the novel: “Деревня, что ль, такая в память будущего есть?..."24). "Идти по земле" 25 is a desire and need not only Zakhar Pavlovich (in connection with the position of which this phrase appears in the text), but almost of all the characters of the novel: Sasha Dvanov, Kopenkin, Gopner. In the city of Chevengur there is even a "regular pedestrian" Luy, who believes that “коммунизм должен быть непрерывным движением людей в даль земли"; he is convinced that it is the "joy of movement" that is a kind of primary source and the main factor of all overcoming in the world (with all the paradoxes and even absurdities of the character's logic, his 'discoveries' are very attractive, for example: “отчего летит камень: потому что он от радости движения делается легче воздуха",26).

But not only the "real" road is significant in Chevengur. In the motive of the path, Platonov reveals a whole complex of metaphorical meanings. The most important thing is the "life way", the spiritual movement, the development of the characters.

Such a conditionally symbolic meaning "road-way" acquired in ancient times, which is embodied in the mythological models of the world among various nations. A known researcher of archaics and mythopoetics V. Toporov points out that "in many mythological and religious traditions, the mythologem of the way appears metaphorically, as a designation of a line of behavior (especially often moral, spiritual), as a set of rules, law, and doctrine" 27 .

In the artistic and aesthetic sense, the concepts of "road" and "way", being closely interconnected, still differ. Yu. Lotman notes on this: "Road" is a certain type of art space, "way" is the movement of a literary character in this space. The "way" is the realization (full or incomplete) or the unrealization of the "road" 28 . Further, Yu. Lotman emphasizes that "with the advent of the image of the road as a form of space the idea of the way is formed as a norm of human life, peoples, humanity. Characters are sharply divided into moving (characters of the way) and motionless"29.

The idea of the way in Chevengur is most fully embodied by Alexander Dvanov - a key character, is regarded as the embodiment of author's ideas

${ }^{24}$ Платонов А. П. Чевенгур..., 186.

${ }^{25}$ Ibid., 30.

${ }^{26}$ Ibid., 218.

${ }^{27}$ Топоров В. Н. Путь. Мифы народов мира. Энциклопедия. В 2-х т. Москва : Сов. энциклопедия, 1980. Т.2. К-Я. С. 353.

28 Лотман Ю.М. Проблема художественного пространства в прозе Гоголя. Избранные статьи. В 3-х тт. - Таллин : Александра, 1993. Т. 1. С. 413-447.

${ }^{29}$ Ibid., 446. 
in the novel. His image symbolizes the very process of becoming a person along the way. The road/way acquired significance already in the childhood of the hero. He, as a "rootless orphan", a "parasite" who has taken root in alien house, is sent with a pauper scrip to beg in the city. The narrative emphasizes the moment of access to the road and the description of the road itself: "Прохор Абрамович наклонился к сироте. - Саша, ты погляди туда. Вон, видишь, дорога из деревни на гору пошла - ты все так иди и иди по ней"30. "Дорога из деревни на гору" - this is the way that V. Toporov calls the most important kind of mythologem of the way, the way from home "to the strange and terrible periphery" 31 . In the psychological perception of the boy himself, the road becomes a sign of "strange and terrible": "На высоте перелома дороги на ту, невидимую, сторону поля мальчик остановился. В рассвете будущего дня, на черте сельского горизонта, он стоял над кажущимся глубоким провалом, на берегу небесного озера. Саша испуганно глядел в пустоту степи; высота, даль, мертвая земля - были влажными и большими, поэтому все казалось чужим и страшным..."32.

However, gradually the movement to the "periphery" turns for the protagonist of the novel into the second kind of path mythology - the movement to the sacred center, "when the highest good is acquired by gradually approaching it" ${ }^{\prime 3}$. The city of Chevengur, where Sasha Dvanov goes, is an idea city, a city of "communism" (see above on the identification of the city and communism). Along this path, Alexander Dvanov has to overcome a lot of difficulties, and this is very symptomatic, since "the difficulty of the path is a constant and inalienable property, to move along the path, to overcome it is already a feat, asceticism from the side of a moving ascetic, traveler" 34 .

There is a train wreck, dreams about the road, a fatal wound, and a serious illness (it lasts, by the way, nine months and ends with a new exit onto the road, which is accompanied by significant commentary by the narrator: “Жизнь снова заблестела перед Двановым...”35). Overcoming all these "difficulties" can very well be assessed as the character's initiation - the assertion of his high mission, which was revealed to him in

\footnotetext{
${ }^{30}$ Платонов А. П. Чевенгур..., 42.

31 Топоров... С. 352.

32 Платонов А. П. Чевенгур..., 43-44.

${ }^{33}$ Топоров..., 352.

${ }^{34}$ Ibid.

${ }^{35}$ Платонов А. П. Чевенгур..., 90.
} 
a dream in conversation with his father when he tells his son: “Делай чтонибудь в Чевенгуре: зачем же мы будем мертвыми лежать...”,

The goal - "city-communism" - to which Alexander Dvanov takes so long and hard, is deprived of analogues in the world and contrasted with the whole "other" world in its spatial and temporal dimensions. "Какой тебе путь, когда мы дошли...", “история кончилась"37, - in these significant expressions of the Chevengur leader Chepurnyi, there is a complete stop in the "city-communism" of any movement - in its direct and figurative meaning. In such a quality - as the end of the road, the antithesis of the movement - Chevengur, of course, must perish. But even before the immediate destruction of the Chevengur utopia, its organizers, in fact, themselves abandon this embodied idea. Having created a city closed in itself, stopped in space and time, they, as it turns out, are not able to live without movement. There comes a time when each of the adherents of "ultimate happiness" "gets tired of standing" and is about to set off again. The above-mentioned Luy, the staunchest proponent of "walking", offers Chepurnyi, “чтобы тот объявил коммунизм странствием и снял

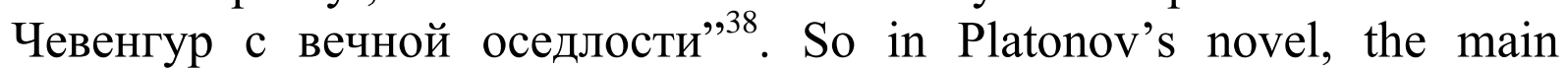
passion of the Russian soul declares itself - the attraction to pilgrimage. Ultimately, it is movement and open space that remain the last refuge of Russian people. Truly in this novel the most convincing confirmation is the idea that "Russia is carried out as an endless dialogue between St. Petersburg and Russia, the city and the road. Read the "gorod" on the contrary - the "doroga" will come out: they are antipodes. Petersburg is a "place", a point, and Russia is a path-road"39.

As we see, the space in Platonov's novel appears not just as a territory for the unfolding of an action, but turns into a universal category, forming a special kind of existential phenomenon. The uncertainty of the spatial spheres, the lack of topographic accuracy, the confusion of man in space, obviously, are aimed at emphasizing the vagueness and uncertainty of a person's position in the world, his existential "abandonment" (S. Kierkegaard), the loss of meaning and purpose of existence, and the feeling of painful impossibility to escape beyond the empirical world.

\footnotetext{
${ }^{36}$ Ibid., 241.

${ }^{37}$ Ibid., 315.

${ }^{38}$ Ibid., 218.

39 Гачев Г. Д. Национальные образы мира. Москва : Советский писатель, 1988.
} C. 386 . 


\section{The space of text in a Platonov's fiction}

Now let's take a look at what Platonov's prose is from the point of view of "space of text", again on the example of the novel Chevengur. We will take into account how the idea of spatial form is realized at different levels of the poetics of the novel: in the plot-composition structure, in architectonics, in the structure of characters, in the isomorphism of architectonic form and syntactics of linguistic units. In relation to the plot action, Chevengur is characterized by discreteness and "randomness" of events; there are many "independent" episodes and characters in the novel, that are loosely interconnected. Many of them generally fall out of the main plot (such as the situation with the teacher Nekhvoraiko or the impoverished Firs). In their sequence, individual episodes of the novel do not explain the previous ones and do not eventually prepare the subsequent ones. The non-causal nature of the development of the action is exacerbated by the absence of external eventual conflict tension, and the author's detachment gives the impression of disconnectedness and fragmentation of the episodes, uncontrolled development of the plot, its free "self-creation".

Trying to retell the plot (more precisely, the plot, in accordance with the distinction of these concepts in the traditions of the formal school), or even doing page-by-page commenting "after the author", as Ye. Yablokov does, we can conclude that the plot structure has a fairly traditional look linear time-based deployment with sequentially strung episodes. In Chevengur, these are the movements of Alexander Dvanov and Kopenkin "across Russia" in search of "amateur communism". But in this case, we draw a zigzag, recursive plot of the work into a straight line. In fact, the line of direct movement all the time tries to turn into movement in a circle, returning to the same points closer to the center of this circle, for example, father's death for Alexander Dvanov or Kopenkin's tendency towards Rosa Luxemburg.

It is important to note the characteristic changes that the text architectonics undergo as the story unfolds. At first, it gravitates towards realistic aesthetics (part 1). In any case, there is still no cardinal break with realistic tradition, although the potential for overcoming it is considerable, it's enough to recall the scenes of the death of children on the first pages of Chevengur. However, gradually the properties of the classical text in the novel are lost. Strange and unusual actions, already set by the first phrases of the novel, develop into "non-fantastic fantasy" (Yu. Mann), built on the principles of a dream vissions or a game of imagination.

The originality of the plot correlates with the overall architectonics of the work. Platonov does not divide the text into chapters and sections, 
although he creates special gaps in it, the purpose of which, apparently, is to direct reading in a certain way. Episodes are simply strung in chronological order one on top of another, without claiming to be some kind of "special" organization, i.e. they form so-called cumulative structure, which is recognized by many researchers of modernist prose as one of its most significant features ${ }^{40}$.

As for the internal, deep linkages of the text, the structuring of material is carried out mainly on the basis of motive connections and parallels. A vivid example of motivness as a structural-organizing principle of the text is the implementation the death motive as a special "return" to the original source of life in a number of episodes of the novel: the death of a train driver, the death of an unnamed Red Army soldier after a train crash, the death of a merchant Schapov, and the Sasha Dvanov's immersion in the waters of Lake Mutevo.

Another important aspect concerns the correlation of the classical and modern versions of the spatial text is the structure of the character's. In a realistic novel, it is determined by a fairly stable scheme: the actions of the heroes and their motivation by the narrator and by the heroes themselves; biography and appearance; interior and landscape; "explicit" and "secret" psychologization (L. Ginzburg), etc. In modernist literature, this scheme is largely losing its significance. The sharp changes in characterology were caused, first of all, by the concept of personality, which is reflected in one way or another in a wide variety of works correlated with the phenomenon of modernism. Its essence in the most general form is expressed by the Joyce's formula from Ulysses: «Everyman or Noman». In another novel by Joyce - Finnegans Wake - the most important leitmotif associated with the image of the Common Man is conveyed by the acronym HCE, which can be decrypted in different ways (Here Comes Everybody or Haveth Children Everywhere), but the meaning of which in any case comes down to the idea of depersonalization of the personality, supremacy of universal archetypal qualities. ${ }^{41}$.

Like other modernist works, Chevengur is very far from traditional fictional characterology. The biographical data of the characters of the novel are extremely scarce; their appearance, as a rule, comes down to one or two details; the inner world, if it is revealed, is basically without the analytic penetration of the narrator into it. The connection at the level of

40 See, for example: Федоров В. В. Кумулятивный принцип сюжетостроения в неклассической поэтике : Дисс. ... канд. филол. наук.. Тверь, 2011. 172 с.

${ }^{41}$ See: Корнуэлл Н. Дж. Джойс и Россия. - Санкт-Петербург : «Акакдемический проект, 1997. С. 51, 57. 
"character - plot" is already indicative. The participation of the characters in the development of the action is minimized (in the sense that plot is not driven by causal patterns of their actions, but mainly by the will of the author, who freely combines events and spatio-temporal plans of the narrative). Moreover, the motivation for the actions of characters is extremely reduced or clearly illogical. It is enough to recall the "voluntary" death of Alexander Dvanov's father, who "думал все об одном и том же - об интересе смерти" and drowned in the lake because "хотел посмотреть - что там есть: может быть, гораздо интересней, чем жить в селе или на берегу озера; он видел смерть как другую губернию, которая расположена под небом, будто на дне прохладной воды, - и она его влекла" ${ }^{\text {"42 }}$, or actions of the Chevengurs when they dump a tank with a singing woman inside it into a ravine, etc.

Of particular interest in the field of character poetics in Chevengur are the features of the disclosure of the human inner world. It seems that Platonov completely refuses such traditional means of psychologization as an internal monologue, free indirect speech. His attention is attracted by a special psychological phenomenon - the "elementary nature" of human psychology. It is known that from the end of the 19th century a whole branch of "elementary" psychology developed (in another way, empirical, that is, proceeding from the idea of the predetermination of the human psyche by concrete sensory experience). In Chevengur we are facing fact that the inner world of characters appears as something like a "conglomerate" of psychic elements (compare about Chepurnyi: "в голове его, как в тихом озере, плавали обломки когда-то виденного мира и встреченных событий, но никогда в одно целое эти обломки не слеплялись, не имея для Чепурного ни связи, ни живого смысла...”, ${ }^{43}$. The form of expression of such a phenomenon in the novel is not the narratological features of the style, but the actual speech sphere of the characters and the author (as close as possible to them). This is manifested in the consistent linguistic embodiment of the Platonov's idea that there is nothing in the human mind that would not be in his sensations. Accordingly, the characters' speech contains only what is present in their sensory perception of the environment and even imagined by them. Hence the following "strange" phrases in the speech of the narrator and characters

\footnotetext{
${ }^{42}$ Платонов А. П. Чевенгур..., 28.

${ }^{43}$ Ibid., 206.
} 
of the novel: “слушал внимательным умом"44; “со своим слушающим чувством"45; “"зорко вспоминала всю жизнь” 46 .

The inner world of the characters, seen by the author who is "inside the depicted consciousness" (L. Shubin), is devoid of linearity, it constantly gravitates toward diverse, "fan-shaped" branching and actualizes the need for perception not of the temporal (that is, sequential and causal), but of the spatial (that is, simultaneous and integral).

The language form of the novel is also organized in such way. Platonov's language style itself is a huge research problem, so we will focus exclusively on some principles of the correlation between language elements and the text as a whole, in particular, on the isomorphism of the syntax and architectonics of the novel. In an interesting study by E. Rudakovskaya, the most important features of the syntax of Platonov's sentence were identified: "an abundance of polynomials, union-free sentences in which simple ones are connected by indirect connection, authorization, repetitions, parallelisms of constructions, uneven logical structuring of the reported material, multicomponent complication, syntactic homonymy, convergence..." $"$. This structure of syntax corresponds to the general architectonic construction of the novel, in which there is no division into separate structural parts, and to the movement of the novel plot, built, as was noted above, in accordance with the cumulative principle. This allows us to discover new shades of the artistic philosophy of the novel in each new episode and in every overtone of the linguistic system, while permanently correcting the author's position and the reader's perception.

Thus, at different levels of the artistic structure of A. Platonov's novel "Chevengur", a specific correlation of textual elements is traced based on non-causal connections and the replacement of sequence in time by simultaneity in space. This allows us to see in this work one of the brightest examples of spatial form in the literature of the twentieth century.

\section{CONCLUSIONS}

The analyses of A. Platonov's prose in the light of spatial theory in literature allow us to draw the following conclusions. There are two different aspects of spatiality in Platonov's fiction: "space of life" (the

\footnotetext{
${ }^{44}$ Ibid., 243.

${ }^{45}$ Ibid., 248.

${ }^{46}$ Ibid., 299.

${ }^{47}$ Рудаковская Э. Роман Андрея Платонова «Чевенгур»: синтаксис предложения и построение текста Русская филология. Тарту, 1996. № 7. С. 230.
} 
relation between real socio-historical space and fictional one), and "space of text" (specific language of modeling of a text and a system of relations between textual elements based on substitution of sequence in time on simultaneity in space).

"Space of life" in Platonov's works is closely connected with the dramatic events of his time, which in a specific refraction occupy all the space of the writer's works. The best example of the uniqueness of the Platonov's transformation of real time and space is the novel Chevengur. The plot of the novel takes place in a specific historical time-space on the eve of the 1917 revolution and in the post-revolutionary years. However, the events of the "great" story are not included directly in the field of the plot action of the work, but serve only as a background for depicting the wanderings of characters in search of "the meaning of a separate and common existence". The uncertainty of the spatial spheres, the lack of topographic accuracy, the confusion of man in space are aimed at emphasizing the vagueness and uncertainty of a person's position in the world, his/her existential "abandonment", the loss of the meaning and the purpose of existence, and the feeling of painful impossibility to from the empirical world.

Consideration of Platonov's Chevengur from the point of view of "space of text" shows that all elements of the novel's artistic structure correlate with the concept of spatial form. The plot of the novel is marked by discretion; there are many "independent", loosely connected episodes and characters. In their sequence, individual episodes of the novel do not explain the preceding and do not prepare? the subsequent ones. The noncausal nature of the development of action is exacerbated by the absence of exotic conflict tension, and authorial detachment creates the impression of disunity and fragmentation of episodes, lack of control in the plot development, its free "self-assertion". The narrative model of the novel is determined by the rejection of the omniscient author. The "obscurity" of the narrator's position correlates with the "wandering" point of view, when the author allows co-existence of the opposing views in the text. This method is extended to the actual narrative "points of view" (focuses of the vision), extremely mobile and mutually interdependent.

\section{SUMMARY}

The article deals with the problem of spatiality in A. Platonov's fiction. The author interprets spatiality in two characteristics: as a specificity of a transformation of real time and space and as a specific language of modeling of a text and a system of relations between textual elements based on substitution of sequence in time on simultaneity in space. Both of 
these aspects reflect Platonov's attempts to create an amalgamation of social, ideological, national, archaic and modern approaches in resolving the problem of human existence. The writer focuses uncertainty on the spatial spheres and the confusion of a man in space emphasizes the vagueness and uncertainty of a person's position in the world. Different levels of the artistic structure of Platonov's novel Chevengur demonstrate a specific correlation of textual elements is traced based on non-causal connections and the replacement of sequence in time by simultaneity in space. This allows us to see in Platonov's work one of the brightest examples of spatial form in the literature of the twentieth century.

\section{REFERENCES}

1. Бахтин М. М. Вопросы литературы и эстетики. Исследования разных лет. Москва : Художественная литература, 1975. 504 с.

2. Гачев Г. Д. Национальные образы мира. Москва: Советский писатель, 1988.445 с.

3. Гугнин А. А. Магический реализм в контексте литературы и искусства XX века: феномен и некоторые пути его осмысления. Москва, 1998. 117 с.

4. Замятин Д. Н. Империя пространства: географические образы в романе А. Платонова «Чевенгур». Филологические науки. 2000. № 1. C. 14-23.

5. Левин Ю. От синтаксиса к смыслу и далее («Котлован» А. Платонова). Семиотика и информатика. Вып. 30. Москва, 1990. C. 115-148.

6. Лотман Ю. М. Заметки о художественном пространстве. Избранные статьи. В 3-х тт. - Таллинн : Александра, 1992. Т. 1. C. $448-463$.

7. Лотман Ю. М. Структура художественного текста. Об искусстве. Санкт-Петербург : «Искусство - СПБ», 1998. С. 14-285.

8. Лотман Ю. М. К проблеме пространственной семиотики. Ученые записки Тартуского государственного университета. Семиотика пространства и пространство семиотики. Труды по знаковым системам XIX. Тарту, 1986. Вып. 720. С. 3-6.

9. Лотман Ю. М. Проблема художественного пространства в прозе Гоголя. Избранные статьи. В 3-х тт. Таллин : Александра, 1993. Т. 1. C. 413-447.

10. Платонов А. П. Чевенгур: [Роман] / Сост., вступ. ст., коммент. Е. А. Яблокова. Москва : Высшая школа, 1991. 654 с. 
11. Подорога В. Евнух души. Позиция чтения и мир Платонова. Параллели (Россия - Восток - Запад). Альманах философской компаративистики. Вып. 2. Москва, 1991. С. 33-82.

12. Рудаковская Э. Роман Андрея Платонова «Чевенгур»: синтаксис предложения и построение текста Русская филология. Тарту, 1996. № 7. С. 226-235.

13. Топоров В.Н. Пространство и текст. Текст : семантика и структура. Москва : Наука, 1983. С. 227-284.

14. Топоров В.Н. Путь. Мифы народов мира. Энциклопедия. В 2-х т. Москва : Советская энциклопедия, 1980. Т. 2. К-Я. С. 352-353.

15. Яблоков Е.А. На берегу неба (роман Андрея Платонова «Чевенгур»). Санкт-Петербург : Изд-во «Буланин», 2001. 376 с.

16. Frank, J. Spatial Form 30 years after. Spatial Form in Narrative. Ed. by J. R. Smitten and A. Daghistany. Ithaca; London : Cornell University Press, 1981. P. 202-244.

17. Frank, J. Spatial Form in Modern Literature. Critiques And Essays In Criticism. 1920-1948. Selected By Robert Wooster Stallman. The Ronald Press Company. New York, 1949. P. 315-328.

18. Frank, J. The Widening Gyre: Crisis and Mastery in Modern Literature. New Brunswick, N.J. : Rutgers University Press. 1963. 278 p.

\section{Information about the author:} Keba O. V.

Doctor of Philological Sciences, Professor at the Department of Foreign Languages, Kamianets-Podilskyi National Ivan Ohiienko University 61, Ivan Ohiienko str., Kamianets-Podilskyi, 32302, Ukraine 


\section{THE GERMAN INTERCULTURAL NOVEL OF THE $21^{\text {ST }}$ CENTURY. «THE GREAT HOMECOMING» BY ANNA KIM}

\section{Pomohaibo J. O.}

\section{INTRODUCTION}

From a periphery to the centre: ascension of immigrants' fiction to the intercultural German literature

In the last thirty years of the $20^{\text {th }}$ century there occurred a gradual change in the face of German national literature due to the migrant-writers' literary contributions. Their literature emerged on the crest of great migratory processes - the tides of guest-workers from Mediterranean areas in 1950s -1960s as well as political asylum seekers from Eastern Europe (since 1968), Latin America (since 1973), Libia, Iran and Syria (1970s), South and Eastern Europe (late 1980s) ${ }^{1}$. The works of the writers having a migratory past were initially treated as a peripheral phenomenon and in 1980s they were collectively given the names - Gastarbeiterliteratur ("guest workers' literature") and Migrantenliteratur ("migrants' literature") which rather pointed at the authors' social and legal status, while often disregarded the literary formal aesthetic criteria and merits. According to $\mathrm{M}$. Durzak, these writings embraced the texts expressing the new settlers' moods, speaking about hardships of work and assimilation in Germany, and mostly addressed readers who found themselves in a similar situation $^{2}$.

Since late 1990s the migrant writers' literature which had occupied a peripheral position in 1970s - 1980s was receiving recognition of a wider readers' audience and finally became a weighty segment of the literary process. M. Durzak points out that it obtained its "independent voice having its own aesthetic coloring which essentially enriched the chorus of modern writers with a new expressive shade"3. Several factors helped effect this, among which were growing volume of literary products,

${ }^{1}$ Chiellino C. Einleitung. Die Literatur des Konsens und der Autonomie - Für eine Topographie der Stimmen. Interkulturelle Literatur in Deutschland. Ein Handbuch. Weimar, 2007. S. 51.

${ }^{2}$ Durzak M. Die Erzählprosa der neunziger Jahre. Geschichte der deutschen Literatur von 1945 bis zur Gegenwart. München, 2006. S. 998.

${ }^{3}$ Ebd. S. 998. 
broadening writers' circle as the migrants' second and third generations were coming into play, as well as attention and support of cultural foundations and institutes (in particular, the Goethe Institute) and literary prizes. The Adelbert von Chamisso Prize, which since 1985 has been an annual award for those who write in German as a foreign language, has attained a position of especial prominence. Among its laureates were Natascha Wodin, Emine Sevgi Özdamar, Feridun Zaimoğlu, Saša Stanišić, Terézia Mora, Marjana Gaponenko. Moreover, the recent trends have shown that the most prestigious literary prizes (including the German ones) are more often awarded writers with a foreign cultural background. Thus, the 2009 Nobel Prize for Literature was awarded Herta Miller, a GermanRomanian woman-writer. The Leipzig Book Fair Prize winners were Terézia Mora (2005), Saša Stanišić (2014), Natascha Wodin (2017), the Ingeborg Bachmann Prize was awarded Ukrainian women-writers Tanja Maljartschuk (2018) and Katja Petrowskaja (2013), a Russian Olga Martynova (2011).

The social and demographic situation has proved that the literature created by authors with a foreign cultural background is both timely and to the point. The present-day Germany is "an emigrant community with a growing ethnic and cultural heterogeneity" 4 . The early $21^{\text {st }}$ century saw more powerful globalizing processes, growing numbers of migrants and refugees from Middle East and North Africa. According to the data provided by the Federal Agency for Political Education (Bundeszentrale für politische Bildung), every fourth resident of contemporary Germany relates to a group of people having a migrant past. Their number in 2017 was as high as $24 \%$ of all German population (19 million out of total 82 million). Consider one more fact $-39 \%$ of children up to 5 years of age have a migrant past. This means that a portion of former migrants living in Germany and, generally, in Europe is expected to grow ${ }^{5}$.

The scholars of literature doing research in multicultural texts (I. Amodeo, A. Blioumi, C. Chiellino, M. Durzak, K. Esselborn, H. Schmitz), note both expansion of the body of texts and the number of notions used to identify the literature in question. The following terms can

${ }^{4}$ Schmitz H. Einleitung. Von der nationalen zur internationalen Literatur. Von der nationalen zur internationalen Literatur. Transkulturelle deutschsprachige Literatur und Kultur im Zeitalter globaler Migration. Amsterdamer Beiträge zur neueren Germanistik. Amsterdam; NY, 2009. S. 7.

5 Bevölkerung mit Migrationshintergrund I. In absoluten Zahlen, Anteile an der Gesamtbevölkerung in Prozent, 2017. Bundeszentrale für politische Bildung. 26.09.2018. URL: https://www.bpb.de/nachschlagen/zahlen-und-fakten/soziale-situation-in-deutschland/ 61646/migrationshintergrund-i 
be encountered among numerous definitions that have replaced the names Gastarbeiterliteratur and Migrantenliteratur. They are: the other German literature (die andere deutsche Literatur), literature with a migration background (Literatur mit Migrationshintergrund) or post-migrant literature (postmigrantische Literatur), intercultural literature (interkulturelle Literatur), transcultural literature (transkulturelle Literatur). In contrast to the former definitions, it is the works' aspects having to do with content and aesthetics that come to the foreground rather than sociocultural or biographical ones. "The literature of migration" had as a determining factor a direct experience of migrating to a different country, whereas "the intercultural literature" is no more concerned with the phenomenon of emigration and more closely conforms to the spirit of the age of globalizing.

C. Chiellino, researcher of literature and poet from among former migrants, is author of a programmed work Interkulturelle Literatur in Deutschland (2007) in which he treats this literature as "a product that has become part of the official cultural production" rather than as an artistic product of cultural minority ${ }^{6}$. In his review of contemporary intercultural literature he classifies texts following the principle of the writers' national origin (literatures of Italian, Greek, Spanish, Portuguese, Turkish minorities, the literature of Russian Germans and emigrants, of Romanian German-speaking minority, of writers from former Yugoslavia, Brazil, Latin America, Africa, Asia and Arab countries). C. Chiellino's theoretical generalizations regarding intercultural literature appear to be of particular importance.

1. The texts belonging to intercultural literature have common thematic orientation. The scholar defines the main topical scope characteristic of the former migrants' literature in this way: "Confrontation with personal history which has led to emigration, exile, repatriation or travelling to alien countries, acquaintance with foreign culture, society and language; a project of new identity based on parity and shared by both citizens and foreigners; integration in the labor world and daily life of a receiving country/former or new motherland; confrontation with political developments in the country of origin; gender-oriented perception of one's

${ }^{6}$ Chiellino C. Einleitung. Die Literatur des Konsens und der Autonomie - Für eine Topographie der Stimmen. Interkulturelle Literatur in Deutschland. Ein Handbuch. Weimar, 2007. S. 57. 
own presence in the system of ethical values with different aims and priorities" $"$.

2. Intercultural literature's distinctive feature is the invariable availability of the reader it addresses (the texts are written for Germanspeaking majority) as well as its inherent dialogue form. C. Cheillino points out that in their attraction to the dialogue the writers manifest their desire to constructively participate in building Germany's future ${ }^{8}$. The authors' deliberate choice of German in the bilingual/multilingual situation is also noteworthy as their preference of their new motherland's language is a signal of their readiness for a dialogue.

3. One more distinctive feature of the books written by intercultural authors is their choice of characters with intercultural biographies, who, like the authors themselves, have plural/hybrid identity. All identity components coexist simultaneously and in parallel in the intercultural novel in which every ego is autonomous, has full value and manifests completion of a definite stage in the character's intercultural biography. In C. Chiellino's opinion this handling of the identity problem helps the authors' to overcome "the so-called alienation of living in a foreign country" and focus the problem "that equivalent cultures are not synchronous",.

4. The next property of intercultural texts, according to Chiellino, is balancing between "consensus and autonomy". On the one hand, the authors are striving to infiltrate the common literary stream, join timerelevant currents and trends of contemporary literature (konkrete Poesie, Frauenliteratur, literature of the 1968 generation), while on the other hand, specific intercultural themes remain prevalent. This makes the given type of literature with its unique attitude to the new language an autonomous part of the literary process.

An important role in developing a new approach to handling intercultural literature was played by the works of I. Amodeo, a reseacher of Italian origin (Die Heimat heißt Babylon, 1996). Asserting that conventional techniques of literary research which focused aspects of content while ignoring poetics of this literature had been exhausted, she suggested applying G. Deleuze and F. Guattari's post-structural theory, in particular, the concept of rhizome, to German multicultural literature. She

${ }^{7}$ Chiellino C. Einleitung. Die Literatur des Konsens und der Autonomie - Für eine Topographie der Stimmen. Interkulturelle Literatur in Deutschland. Ein Handbuch. Weimar, 2007. S. 58.

${ }^{8}$ Ebd. S. 59.

${ }^{9}$ Ebd. S. 61 
mainly concentrated on aesthetic features common for "heterogeneous marginal literature abroad" (heterogene Randliteratur in der Fremde) ${ }^{10}$. Referring to the writings of French scholars, I. Amodeo introduced the concept of root-rhizome as "a non-centred, non-hierarchical system" with its characteristic "diverse and variable cohesions and ties" "11. She thinks that transferring this model to literature will enable adequately describing the dynamic and non-uniform phenomenon - the literature created by foreign writers ${ }^{12}$. From I. Amodeo's point of view, "rhizomatic aesthetics" realizes itself in intercultural texts as:

1) Redevielfalt: an immanent diversity of languages which can reveal itself in a text both explicitly (if, for example, several languages or dialects are present there) and implicitly, that is, the text starts a dialogue with another language (see Bakhtin's dialogue form principle).

2) Befremdung - "a specific rhizomatic semantic blending" revealed on the level of a text's content-relevant and motivating structure as overlaying and crossing of "the native" and "the alien".

3) Stylistic syncretism (Renate Lachmann) ${ }^{13}$.

In general, rhizomatic aesthetics of the intercultural literature is a result of the encounter of cultures, interweaving and mixing of different cultural traditions and abandoning "the native versus the alien" opposition. The following features may be attributed as its major artistic peculiarities: heterogeneity, dynamism, diversity of languages, style syncretism (in accordance with G. Deleuze and F. Guattari's rhizomatic model) ${ }^{14}$.

\section{Anna Kim as a representative of German-Korean literature}

Writers from Asian countries represent the most heterogeneous literary group among various affiliations of intercultural literature. U. Reeg, author of the review chapter "Writers of Asian Cultural Region" in the abovementioned book Interkulturelle Literatur in Deutschland puts together writers from India, Indonesia, Vietnam, Thailand, China, Japan, Korea and

${ }^{10}$ Amodeo I. Die Heimat heißt Babylon. Zur Literatur ausländischer Autoren in der Bundesrepublik Deutschland. Opladen, 1996. S. 201.

${ }^{11}$ Ebd. S. 108.

12 Amodeo I. Betroffenheit und Rhizom, Literatur und Literaturwissenschaft. Migrationsliteratur. Eine neue deutsche Literatur? Berlin : Heinrich Böll Stiftung, 2009. S. 7-8.

${ }^{13}$ Amodeo I. Die Heimat heißt Babylon. Zur Literatur ausländischer Autoren in der Bundesrepublik Deutschland. Opladen, 1996. S. 204.

14 Esselborn K. Deutschsprachige Minderheitenliteraturen als Gegenstand einer kulturwissenschaftlich orientierten ,interkulturellen Literaturwissenschaft“. Die andere deutsche Literatur. Istanbuler Vorträge. Würzburg, 2004. S. 21-22. 
Mongolia. Admitting that the essential characteristic of this group of writers is very heterogeneous and the ensuing text genre and theme diversity is all-embracing, she finds, nevertheless, some contiguous points in the common stream of German-Asian literature. U. Reeg notes that, first, in contrast to, for instance, people from Iran and Iraq, most writers from this group emigrated to Europe not because of political repressions but for reasons of personal interest as, for example, passion for the German language, literature, getting a job and desire to be more closely acquainted with the European country. Second, a number of general "acute problems" may come to the foreground which characterizes the German language literature created by the authors of Asian origin. Here belong: a) confrontation with the new social environment and the German language; b) cultural transformations conditioned by the historical changes in the country of origin; c) women's identity and role ${ }^{15}$.

These observations and conclusions are very timely and appropriate today and they are also relevant in respect of Anna Kim, German-Korean writer. She was born in Daejeon, South Korea in 1977. Her family moved to Germany in 1979 and then to Vienna where she has been living since 1984. Kim's parents emigrated to Europe not for political reasons but due to their professional interests - her father had been studying "Western art" and her mother - German philology. The writer admits, however, that Park Chung-hee's regime strengthened their intention to leave South Korea. Like many emigrants' children, Kim seldom visited her motherland where she came first when she was 11 . The second "coming back" took place when she was working on her novel The Great Homecoming. Anna studied philosophy and theatre art in Vienna, had practical training in London and Oxford. Since 1999 her short stories and poems have been published in manuskripte, zwischenzeit and VOLLTEXT magazines. Kim is well known as the author of short story Die Bilderspur (2004), novels Die Gefrorene Zeit (The Frozen Time, 2008), Anatomie einer Nacht (The Anatomy of a Night, 2012), Die Grosse Heimkehr (The Great Homecoming, 2018). Her art has been distinguished with prestigious awards in literature; she was awarded the Literary Prize of the European Union in 2012.

The Object of our research in the present article is poetics of Kim's intercultural novel The Great Homecoming. The aim of the paper is to analyze the novel's cross-cultural "rhizomatic" aesthetics on the novel's plot-content, genre, composition and stylistic levels. We assume that the

${ }^{15}$ Reeg U. Autor/innen aus dem asiatischen Kulturraum. Interkulturelle Literatur in Deutschland. Ein Handbuch. Weimar, 2007. S. 263. 
novel can be attributed as a new type of the multicultural novel, the pattern of a multi-level artistic synthesis. It can combine several genres of mass literature (that makes the text fascinating and highly readable), while the major feature of such a novel is that it must necessarily have context exotic for the European reader. The migrants' traditional themes (search of identity, family and motherland, integration in a new cultural environment, return to the land of ancestors) recede here to the background, acting as an external rather than internal motivating force of the hero's behavior. Attaining actual and full identity as the basic motivation of a hero who lost his ego gives way to an identity game, a bold identity search staging. In full correspondence with the post-modernist author's intention to destroy ideologies and imperatives, there occurs deconstruction of all modern concepts exploited in politics (motherland, history, identity).

It should be also noted that with the exception of a few reviews the novel The Great Homecoming has not yet been the object of scholarly literary study and, furthermore, considering that Kim's literary work has been insufficiently examined on the whole, whereas the vector of intercultural research in contemporary literature in the German language is felt to be more and more time-relevant, we hope that the given research may be found timely and necessary.

The art of every intercultural author is the point of cross-breeding and synthesis of diverse national and ethnic cultural trends. Anna Kim, representing a new multicultural writers' generation, identifies herself as an Austrian woman-writer firmly rooted in the German language cultural background. Nevertheless, the Asian name and appearance shape in her readers a complex of quite specific notions. I. Mangold has so described this "horizon of expectations": "She has a Korean surname and looks Korean, and her new novel's title is The Great Homecoming. These three facts are enough to form an idea about Anna Kim's book before you have read the first page: "Why, this is a novel with a migration setting! The German writer seems to be returning to her ancestors' country!" These German readers' "receptive reflexes", here somewhat simplified, "not that they are basically wrong, they are simply very approximate as they shield the main thing"16. Her observation confirms the following: the readers of today have steady stereotypes about intercultural literature. Their biased attitude to literature "of the authors, who are not only German", predetermines their perception of the texts and affects the work of writers

${ }^{16}$ Mangold I. Alles Spione. Die österreichische Autorin Anna Kim hat einen raffinierten historischen Roman über den Kalten Krieg in Korea geschrieben: "Die große Heimkehr". ZEIT online. 30.03.2017. URL: https://www.zeit.de/2017/12/anna-kim-die-grosse-heimkehr-roman 
who comply with the readers' response and strive to meet their expectations.

Looking at Anna Kim's novel from the viewpoint of readers' expectations, one can assume that The Great Homecoming has succeeded as a specimen of post-modernist "double coding". When the novel was published, the reviewers unanimously appreciated the book's main merits its synthesis of historical, political, love and spy novel traits. Its plot was based on a very confusing story of relations between Yunho, his friend Johnny and Eve Moon with whom they were in love, which were advancing in a very exotic historical setting. The events were taking place in the period of Korea's division after the WWII, Cold War and the beginnings of Kim Il Sung's dictatorship. The writer preserved the elements essential for a multicultural novel (a cross-cultural heroine, motives of searching for a motherland and restoring family ties), however, she put them outside the basic narration. The major theme of the novel is the choice a man has to make between opportunism, political mimicry and preserving one's genuine personality in the situation of permanent instability and chaos. The author puts forth in the foreground an implicit existential and philosophical sense.

The novel's title is poly-semantic and can be interpreted on the "double coding" principle. On the one hand, the story revolves around Hanna, a story-teller, who came to Korea to find her parents, and her return to her motherland. On the other hand, the matter is Anna Kim's addressing the Korean subject. The third point is that the title refers the reader to the historical fact, known in Korea as "the great homecoming"17. A big campaign started in 1959 demanding that Koreans living on the territory of Japan should be returned to North Korea. A historian E.V. Kim writes that the repatriation project was a well-planned propaganda campaign conducted under the conditions of ideological opposition between North Korea and South Korea ${ }^{18}$. Though most Koreans living in Japan had come

${ }^{17}$ Korea was annexed by Japan from 1910 to 1945 as a result of which Korean population was mobilized for labor service in Japan. After 1945 only some portion of Koreans returned to their motherland. The post-war hardships, division of Korea along the $38^{\text {th }}$ parallel and Korean war (1950-1953) were the reasons why Koreans were reluctant to return. By 1945 there stayed more than 2 mln of Koreans in Japan. Most of them returned, however, about 600 thousand decided to stay because political and social situation had become worse. Most of them were from the South but they sympathized with North Korea where since 1955 there had operated "League of Korean citizens living in Japan" which demanded repatriation.

${ }^{18}$ Ким Е. В. К вопросу о возвращении граждан на корейский полуостров: два пути репатриации. Корё сарам. 23.03.2016. URL: http://koryosaram.blogspot.com/2013/03/blogpost_23.html 
from the South, they sympathized with North Korea which promised them jobs, shelter and free education. The repatriation project started in 1959 aided by the Red Cross organization and with participation of Soviet ships. For the novel's heroes "the great homecoming" became fateful - Yunho, Johnny and Eve met at this culmination point, and after that they would lose each other forever.

\section{The Great Homecoming: novel's plot and composition}

The novel's events are evolving in two temporal planes - at present (modern Seoul in 2000s) and in the past (Korea and Japan in 1950s 1960s). The first temporal plane correlates with the story of Hanna, a young girl adopted by a German couple, who came to Seoul to find her parents. This line of the plot serves as a unique framing for the main part of narration - a retrospective monologue of the aged Yunho recalling his youth's events. The heroes' acquaintance in Seoul serves as the intrigue uniting both lines of the plot. Yunho turned to an interpreter with a request to translate a letter he had received from America. It contained information that a certain Mrs. Eve Lewes had died in a nursing home for the aged. As the woman had no relatives, the notice had been sent to the only address found in her belongings. By Yunho's emotions Hanna guessed that there had been some ties between 78-year-old Yunho and Eve. Her question "Who is Eve Moon?" activates his memory and involves the old man in a long process of recollections. His narrative about the friendship with Eve and Johnny stretches for several days and acquires the form of a panoramic life story, beginning with childhood spent in Nonsan, and ending with his expatriation from Japan to Korea. Hanna is an ideal listener to the story of Yunho, an archivist in Seoul, whose story is, on the one hand, balancing between deeply personal narrative confessions with the elements of selfanalysis and, on the other hand, an attempt to objectively reflect and understand the reality, the laws of its historical development. The chapters developing the main plot lines are interrupted with essayistic ones making rather extensive digressions into Korean history.

Besides the frame-type composition of the novel, a fortunate technique for uniting different narrative perspectives (the present - the past, Europe Asia, youth - the experience of aging), and the original architectonics of the novel is worth mentioning. The novel is divided into two parts having equal volumes. In the first part ("Seoul, 1959") all events take place in South Korea. The second part ("Osaka, 1960") transfers the place of action to Japan, the city of Osaka where existed a large community of Korean communist emigrants. In our opinion, this symmetry in dividing the text 
into two equal parts reflects symbolically the "unnatural" Korea's division along the $38^{\text {th }}$ parallel.

All characters of the novel, their lives and destinies are involved in the storms of historical and political events - the post-war break-up of the country, ideological opposition between North Korea headed by Kim Il Sung and South Korea headed by President Syngman Rhee and fights of underground criminal groups. Yunho and Johnny, friends from childhood, were born and grew in Nonsan. Yunho's brother, Yunsu, was involved in activities of North Korean guerilla detachments responsible for disorders in South Korea. When he was arrested, Yunho was suspected of collusion with the communists and declared a traitor. As a result, he had to escape to Seoul to save himself from accusations. In Seoul he met Johnny and his girl Eve Moon and they became friends again. Johnny was mixed up in activities of an ultra-rightist organization "The North-Western Youth" supporting the president Syngman Rhee.

Once when they participated in a demonstration and it was being dispersed, Johnny committed murder and the friends had to flee. By ship they arrived in Osaka. Here in a Korean "ghetto", sheltering Zainichi Koreans, every home paraded Kim Il Sung's portraits and North Korean flags. They made themselves pass for political refugees, "two brothers and a sister", evading Syngman Rhee's repressions. As such, they rented a room in Tetsuya Yamamoto's house. At that time the start of 'the great homecoming" campaign was announced. It so happened that the houseowner's daughter, who had been determined to return to Korea, mysteriously disappeared, and fearing that the blame for her disappearance might be put on Johnny, the friends took advantage of the announced 'homecoming" campaign and planned one more escape. Jonny sailed to North Korea, Eve abandoned her friends and secretly went to America, and Yunho returned to South Korea. Fifteen years had passed before Yunho by chance met Eve and her American husband in Seoul. Eve asked for his address which she had kept until she died.

The novel's system of characters reflects the period of complicated political struggle in which the decisive factors were loyalty and the skill of compromise. Yunho, a weak and apolitical man, is attached a label of being "left". On the whole his sympathies were really more on the side of communists, so that he entered their underground organization. Johnny was rather on the side of the extreme right. He participates in a radical criminal band which did "dirty work" for President Syngman Rhee.

Eve Moon, a Korean dancer, looking like an American girl, turned out to be working as an intelligence agent for South Korean national security service. She was appointed to be close to Johnny as a source of information 
about "North-Western Youth" activities. Johnny was aware of her "assignment" but as he badly needed money he agreed for a "double play". Eve manoeuvres between the two camps, making use of her "lovers". Exploiting her power over Johnny, she talked him into killing Jinman who had learnt about her spying and wanted to blackmail her. When she and Yunho had become more intimate, she decided to make him her informer as well (Yunho evoked interest as "one of the working class"). Unsuspecting Yunho, gave out to her a certain Sangok, his brother's friend, who was of no threat to South Korea but was nevertheless arrested as being potentially dangerous "red".

In fact, the novel's temporal frames are quite wide and embrace the whole Korean history throughout the $20^{\text {th }}$ century beginning with Korea's liberation from Japanese rule (1905-1945), Korea's separation in 1945, Korean war in 1950-1955 and ending with the postwar consequences of South Korea-to-North Korea opposition. Numerous pseudo-documentary digressions and historical references are available in the text.

Nonetheless, the novel The Great Homecoming cannot be taken for a historical novel. Commenting on this, the author points at shortage of archival materials and absence of access to documents: "Many sources were inaccessible, the archives were closed for a long time. Taking into account the lack of objective sources and incredible amount of propaganda, only an imaginative work could be written ${ }^{19}$. The basic reliable sources for Ann Kim were: 1) photo archives; 2) talks with relatives; 3) Korean movies of the 50s in which behind the pretty westernized scenes one could see the streets devastated by the war. One researcher's opinion is that Kim's novel is not a historical narration but a combination of "historical facts, recollections and different interpretations of what was seen and heard". He thinks that the main task of the author was to show "how incomplete was a detailed study of the Korean war and how it reverberates in the present". In appraising the past history "there are too many ifs, unanswered questions and representations of the events which could have happened so or somewhat differently" 20 .

It is interesting that the Austrian (according to Wikipedia) writer A. Kim turned to the Korean theme in the novel The Great Homecoming

${ }^{19}$ Leitner J. Anna Kim im Interview: "Ich schreibe im Jetzt". Tiroler Tageszeitung. 24.04.2017. URL: https://www.tt.com/kultur/literatur/12902919/anna-kim-im-interview-ichschreibe-im-jetzt

${ }^{20}$ Kountouroyanis K. Als die Vergangenheit in die Gegenwart eintrat... Rezension zu Anna Kims Roman: "Die große Heimkehr". Theater und DaF-Unterricht . 2017. Nr. 44. DaFSzene Korea. Berlin \& Seoul. S. 44. 
for the first time. Before that, other "alien" territories had been the places of action in her books - Kosovo and the former Yugoslavia (Die gefrorene Zeit) and Greenland (Anatomie einer Nacht). Her interest in Korea and in the past experiences of her family on the whole emerged when she became interested in politics: "Korea interested me still more than the family circumstances for political reasons. Cold war had always been fascinating for me. It is not surprising that I was greatly impressed by Hungarian refugees on the other side of the Iron Curtain".

This or similar approach, it seems, distinguishes multicultural writers of the new generation from their predecessors. Addressing the past of their own country is dictated by the desire to understand the contemporary problems rather than by the sorrow of the irreplaceable loss of their motherland. A. Kim named the idea of urgency (Dringlichkeit) the motive force of her creative process. In her opinion, there is a multitude of problems one should write about now, urgently and without delay. She considers that the main problem is that of relationship between an individual and the world of politics, the effect of global geopolitical decisions upon the life of every human being. She is convinced that "What is happening on the other side of the world is always inseparable from what is happening directly before $\mathrm{us}^{21}$.

\section{The narrative structure}

There are two narrative instances in the novel (Hanna and Yunho) conducting a dialogue with each other. Hanna, representing the author, speaking with the author's voice in the novel's composional frame, is a heroine evidently possessing autobiographical traits, that is also proved by similar names (Hanna - Ann). Both literary personages (Yunho and Hanna) represent the type of personal narrator-story-teller, i.e. they act at the same time as participants of the events described. Between these narrators' positions there is a great distance (in gender, age, mentality and nationality). Hanna is a young European, fluent in three languages. A 78-year old Yunho is a Korean, who lives as a recluse, and yet, despite the obvious differences, there is something that brings them together: inner loneliness, the feeling of being deprived of any ties and home as well as having a psychic wound: Hanna had been deserted by her parents, and Yunho betrayed by a dear person. Each of them needs the other in his or her own way so as to fill in their soul's emptiness and find spiritual balance. Yunho, revealing his secret to Hanna, restores his bonds with the

${ }^{21}$ Leitner J. Anna Kim im Interview: "Ich schreibe im Jetzt". Tiroler Tageszeitung. 24.04.2017. URL: https://www.tt.com/kultur/literatur/12902919/anna-kim-im-interview-ichschreibe-im-jetzt 
present, and Hanna, in her turn, listening to Yunho's confessions, recovers the lost part of her identity.

Hanna's image in more respects than one corresponds to the concept of a typical character of hybrid identity found in multicultural novels. The profession she works in emphasizes the cross-cultural nature of her image. She is a translator, interpreter, an intermediary between languages and cultures. Hanna's appearance confuses Yunho who expected to see a German girl. "You look like a Korean...You are not like a German at all", - declares he seeing her for the first time. "I am both", - explains Hanna. In reality, she was brought up far from her native culture and language. Thanks to her nanny she learnt Korean, but though Junho identifies her as "one of his people", he notices at once that her speaking Korean is "artificial" and "has a Japanese accent".

The main function of Hanna as a participant in the dialogue is to listen to Yunho, to make him speak. She is a neutral, unengaged figure free from any biased ideas about her own country's history. Thanks to her hybrid identity (a German with Korean looks), the aged story-teller perceives her both as one of his people and a foreigner. After several prolonged talks they had for a few days, Hanna finally understands, why he confided his secret to her and nobody else. "Nun verstand ich, warum er mir die Wahrheit über Eve erzählt hatte: gerade weil wir einander nicht wiedersehen würden. Bei einer Fremden wie mir die Beichte abzulegen, war ungefährlich, denn mir war die Grammatik dieser Gesellschaft unbekannt. Ich kannte sie zu wenig, wusste nicht genug, um den Sünder zu bestrafen, ich war nicht einmal fähig, das wahre Ausmaß der Verbrechen abzuschätzen, in die Johny, Eve und Yunho verwickelt gewesen waren"22.

Hanna's personal motives, Yunho's voluntary listener, are not made distinct enough in the novel. It is obvious that her desire to understand why her mother left her child is what internally motivates her, and though Yunho's story does not have anything to do with her family's goings-on, Hanna feels to have indirectly become part of her ancestors' country history through Yunho's narrative, and she undergoes what I. Mangold calls "existential initiation". This is how A. Kim managed to show that her heroes' destinies are parallel and common. Finally, it occurs to Hanna that history is ambivalent and relative. She will never learn the reason why her mother dropped her, however she will never accuse her.

Both heroes are at one in their feeling of being homeless and deprived of motherland (Heimatlosigkeit). Yunho, for one, had never felt at home in South Korea: he was always reminded that he was a communist and was

\footnotetext{
${ }^{22}$ Kim A. Die grosse Heimkehr [Roman]. Berlin, 2018. S. 538-539.
} 
"on the wrong side". Hanna feels she is a person occupying an intermediate position between the two identities. In Germany she has never been accepted as a German but South Korea has not become a home for her. Having come to Seoul, she concluded that she was not disappointed with South Korea, but rather with her not being able to feel it was her motherland: "Nein, antwortete ich, nicht enttäuscht vom Land Südkorea, jedoch enttäuscht davon, dass es sich nicht wie Heimat anfühlte" ${ }^{, 23}$. A. Kim intended to demythologize the notion of Motherland exploited in politics. Her heroes perceive motherland not as a geographical space but as a place of an individual significance. Hanna says: "Ich glaube nicht an Heimat. Das heisst, ich glaube nicht an den Ort Heimat. [...] Ich glaube, dass es Orte gibt, die man liebt. Ich glaube sogar, dass es Orte gibt, in denen sich die Seele zu Hause fühlt, Seelenlandschaften"24.

Two strategies overlay, and run in parallel to each other. Epical, detailed description of the events is accompanied with lyric rendering of the hero's feelings and sufferings. The space in which converse the main characters resembles a cave "filled with noises and sounds" and piled up with books and vinyl disks ${ }^{25}$. This is a space for memories, a place where past and present cross, where real-time laws are not in effect. People and objects lose their shape, Yunho's figure becomes dematerialized and to Hanna he does not look a living human being, but a photo, a picture woven of light and shade inside which there sounds a voice: "Mit der Zeit meinte ich keinen Menschen vor mir zu haben, sondern eine Fotografie, ein Bild aus Licht und Schatten, in dem eine Stimme lebte, und etwas Rauch $[\ldots]^{, 26}$.

In the memory space, chronology loses its regularity. All clocks in Yunho's flat indicate different time: "die Kuckucksuhr an der Wand schneller war als der Wecker auf der Anrichte und dieser flinker als die Standuhr mit dem tiefen Gong"27. Music creates a special lyric setting in the novel, it carries the hero to the past and evokes nostalgia. The song "Blue Moon" performed by a woman jazz singer Billy Holliday becomes the main tune, leit-motif accompanying their meetings: "Blue Moon, sang Billy Holliday; tatsächlich befanden wir uns auf einem blauen Mond, zwischen uns eine Stehlampe, deren Schein die niedrigen Tische und Kissen, die über dem Holzboden verstreut waren, sowie den gläsernen

\footnotetext{
${ }^{23}$ Kim A. Die grosse Heimkehr [Roman]. Berlin, 2018. S. 280.

${ }^{24}$ Ebd. S. 281.

${ }^{25}$ Ebd. S. 14.

${ }^{26}$ Ebd. S.21.

${ }^{27}$ Ebd. S.24.
} 
Aschenbecher mit einem bläulichen Schimmer überzog, sogar den Qualm blau einfärbte, der der Zigarette entwich [...]"28.

Combining two lines of the plot enables the heroes to move from the past to the present, from the real time dimension to the subjectively experienced time span of their memories. When this happens, the past does always dominate the present. In Yunho's story it revives and becomes "more present than reality". Becoming immersed in his stories, Hanna gets more and more alienated from reality, feels outside the real life, not part of it ("Ich bewegte mich durch die Stadt wie hinter Glas") 29 . The past, forgotten or pushed out the memory while processing the wound, masters the present: "[...] es waren die Stunden, in denen Yunho von der Vergangenheit sprach, die sich gegenwärtiger anfühlten als die Gegenwart, und es war die Gegenwart, die meinen Empfindungen nach vergangen war - vergangen, noch ehe sie angefangen hatte",30.

\section{Identity and the problem of its political instrumentalization}

The instrumentalization of identity is one of the most significant themes of the novel, that is, the use by a person of his or her political or social identity to achieve some particular goals. Eve Moon's image is of special interest from this point of view. If Hanna owes her hybrid identity to not being accepted by either Germans or Koreans as "one of them", Eve changes her identity always to remain on the strong side: "Ich bin auf der Seite der Starken, der schon immer stark Gewesenen und der stark Bleibenden" "31. She had several names - two American ones, one Korean and one Japanese: "Sie war Mrs Henry Lewis, Eve Lewis. Sie war allerdings auch Eve Moon, Yunmee Moon und Mizuki Takahashi" ${ }^{\text {"32. She }}$ easily adapted to any new political situation, changed her roles, appearance, the way she behaved. In one of her interviews A. Kim said that her heroine did not correspond to the Asian idea of a woman. She is strong, active, and in contrast to many she does not take a passive victim's way but a way of a person who feels to be "master of his or her own destiny". When Americans "marched through her country"33, she changed her appearance to suit their beauty ideal, smoked "Lucky Strike", curled locks in her hair dyed blond, put red lipstick on her lips and powder on her face. As a result her face began to look like "a frozen mask", and became an

\footnotetext{
${ }^{28}$ Kim A. Die grosse Heimkehr [Roman]. Berlin, 2018. S. 21.

${ }^{29}$ Ebd. S. 292.

${ }^{30}$ Ebd. S. 293.

${ }^{31}$ Ebd. 182.

${ }^{32}$ Ebd. S. 24.

${ }^{33}$ Kim A. Die grosse Heimkehr [Roman]. Berlin, 2018. S. 47.
} 
embodiment of the Koreans' stereotype of American women. It was this sexually appealing "Americanized Korean girl" that Johnny and Yunho fell in love with. They overlooked her working in brothels for American soldiers - the so-called Dancing Schools, in which Korean girls were also taught how to dance, dress and speak "in the Western way". Here they believed in "the fairy-tale" about an orphan-girl from good family who once had fallen in love with an American soldier. That Eve had in fact been a spy, Yunho learnt much later: "Später lernte ich zwischen der echten und der unechten Eve zu unterscheiden, viel später, als Johny bereits auf dem Weg nach Nordkorea war..."34.

In Japan where the heroes had "to lie low" for the sake of their safety, Eve changes again - this time she posed as a Korean, sister of Johnny and Yunho. She behaves as a typical Korean - a quiet, plain Korean servant girl having no striking features: "Eve, die wie eine Königin durch Seouls Straßen geschritten war, benahm sich in Osaka wie eine Dienerin. Sie sah niemandem ins Gesicht, achtete darauf, ihre Augen gesenkt zu halten, und wenn sie Japanisch sprach, klang sie wie ein Kind" 35 . Even Johnny who had been "a rebel and a mutineer" had to make his identity more pliable, he learnt not to stick out, to change his position, speak about Kim Il Sung with respect and behave "immaculately". The only one who did not have a chance to play strange roles was Yunho having no skills of a liar. Eve remarked about him: "Ein Hase benötigt kein Hasenkostüm" ("A rabbit does not need a rabbit's suit") ${ }^{36}$.

Talking about the past was for Yunho an attempt to realize his life experiences and understand what Eve Moon had been guided by, when she deceived her friends. He is trying to find out why lies and hypocrisy became for her more important that truth, reality and sincere feelings, and generally, if she had any feelings at all - or it was one overall instinct - the instinct of survival ${ }^{37}$. As a result, he acknowledges her right for making a choice - the choice "to be on the strong side, on the side of those who have always been and remained strong". Everything she was saying about patriotism had in fact nothing in common with patriotism ("Eve war so wenig Patriotin wie ich Buddhist bin. Sie hatte lediglich eine Nische gefunden, in der sie leben konnte, wie es ihren Vorstellungen am nächsten kam. Sie hatte ein sehr genaues Bild davon, wie die Welt funktionierte, mit den realen Gegebenheiten gab sie sich nicht ab, den diese waren komplex,

\footnotetext{
${ }^{34}$ Ebd. S. 28.

${ }^{35}$ Ebd. S. 348.

${ }^{36}$ Ebd. S. 349.

${ }^{37}$ Kim A. Die grosse Heimkehr [Roman]. Berlin, 2018. S. 530.
} 
ambivalent, verwirrend"38. The motto the multi-faced Eve-Yunmi has, sounds like this: we don't choose the authorities, our survival depends on how convincing our loyalty is ("wir werden von den Regierenden übernommen, wir können sie uns nicht aussuchen. Und unser Überleben hängt davon ab, wie überzeugend unsere Loyalität ist") $)^{39}$. This emphasizes relativity of historical truth and that all estimates are unreliable and ambiguous. A. Kim demonstrates that in any unstable time when authorities and country frontiers change often, individual identity is hard to keep. Striving to survive, one has to hide his or her real ego behind numerous masks and roles.

\section{CONCLUSIONS}

Our observations may be generalized in the following conclusions:

1. The intercultural novel of the $21^{\text {st }}$ century ceases to remain a peripheral genre as the idea of a nucleus and a centre in literature becomes diffused and displaced. The intercultural literature asserts itself in a similar situation as an important and competitive segment of the contemporary literary process. The Great Homecoming by A. Kim is a model of main stream genre forms in a post-modernist synthesis (spy, love and historical novels), retaining exotic elements characteristic of intercultural literature (place of action, historical political figures, heroes' names and Korean idioms).

2. The author of the new intercultural novel does not position him- or herself as a writer belonging to the intercultural borderline area and working on the crossroad of the two worlds. On the contrary, he or she becomes identified as belonging to representatives of the literature in the German language, well discerning readers' preferences and using the hybrid identity as an advantage.

3. In the emigrants' novel of the 1980s the author perceives the "alien" German culture through a prism of his or her "own" native one, whereas in the new intercultural novel there takes place acquaintance with the country of the author's ethnic origin through a prism of the German culture which is already perceived as a native one. Thus, Hanna arrives in Korea with a set of European values and convictions, but after she meets Yunho, she learns to be more loyal.

4. The intercultural novel is an example of crossbreeding different cultural traditions, of synthesis and dialogue between cultures. This idea is artistically realized in the novel being reflected in its genre form, its peculiar intercultural subject matter and problems touched upon, its

\footnotetext{
${ }^{38}$ Ebd. S. 529.

${ }^{39}$ Ebd. S. 182.
} 
compositional and narrative features as well as its system of heroes and the choice of a hero with a flexible identity.

5. The heroes' interest in family history, their motherland's past emerges in the new novels not as a result of the heroes' becoming aware that they lost their identity. Addressing the past ensues solely from the necessity to solve the problems of the present.

\section{SUMMARY}

The article deals with the poetics of the modern intercultural novel The Great Homecoming by the Austrian writer Anna Kim. The paper examines the novel's cross-cultural "rhizomatic" aesthetics on the novel's plot and storyline, genre, composition and stylistic levels. It is shown that the novel can be viewed as a new type of the multicultural novel, as an example of a multi-level artistic synthesis. It combines several genres of popular fiction (that makes the text entertaining and "readable") and provides the exotic Asian context for the European reader. The migrants' traditional themes (search of identity, family and motherland, integration in a new cultural environment, return to the land of ancestors) recede here to the background. In full correspondence with the post-modernist author's intention to destroy ideologies and imperatives, there occurs deconstruction of all modern concepts exploited in politics (motherland, history, identity). The writer preserved the elements essential for a multicultural novel (a cross-cultural heroine, motives of searching for a motherland and restoring family ties), however, the major theme of the novel is the choice a man has to make between opportunism, political mimicry and preserving one's genuine personality in the situation of permanent instability and chaos.

\section{REFERENCES}

1. Ким Е. В. К вопросу о возвращении граждан на корейский полуостров: два пути репатриации. Корё сарам. 23.03.2016. URL: http://koryosaram.blogspot.com/2013/03/blog-post_23.html

2. Amodeo I. Betroffenheit und Rhizom, Literatur und Literaturwissenschaft. Migrationsliteratur. Eine neue deutsche Literatur? Berlin : Heinrich Böll Stiftung, 2009. S. 6-8. URL: https://heimatkunde.boell.de/sites/default/files/dossier_migrationsliteratu r.pdf

3. Amodeo I. Die Heimat heißt Babylon. Zur Literatur ausländischer Autoren in der Bundesrepublik Deutschland. Opladen, 1996. 223 S.

4. Bevölkerung mit Migrationshintergrund I. In absoluten Zahlen, Anteile an der Gesamtbevölkerung in Prozent, 2017. Bundeszentrale für politische Bildung. 26.09.2018. URL: https://www.bpb.de/ 
nachschlagen/zahlen-und-fakten/soziale-situation-in-deutschland/61646/ migrationshintergrund-i

5. Chiellino C. Einleitung. Die Literatur des Konsens und der Autonomie - Für eine Topographie der Stimmen. Interkulturelle Literatur in Deutschland. Ein Handbuch. Weimar, 2007. S. 51-62.

6. Durzak M. Die Erzählprosa der neunziger Jahre. Geschichte der deutschen Literatur von 1945 bis zur Gegenwart. München, 2006. S. 964-1007.

7. Esselborn K. Deutschsprachige Minderheitenliteraturen als Gegenstand einer kulturwissenschaftlich orientierten ,interkulturellen Literaturwissenschaft“. Die andere deutsche Literatur. Istanbuler Vorträge. [Hrsg. M. Durzak, C. Ş. Ayata]. Würzburg, 2004. S.11-22.

8. Kim A. Die grosse Heimkehr [Roman]. Berlin, 2018. $553 \mathrm{~S}$.

9. Kountouroyanis K. Als die Vergangenheit in die Gegenwart eintrat... Rezension zu Anna Kims Roman: "Die große Heimkehr". Theater und DaF-Unterricht . 2017. Nr. 44. DaF-Szene Korea. Berlin \& Seoul. S. 42-45.

10. Leitner J. Anna Kim im Interview: "Ich schreibe im Jetzt". Tiroler Tageszeitung. 24.04.2017. URL: https://www.tt.com/kultur/literatur/ 12902919/anna-kim-im-interview-ich-schreibe-im-jetzt

11. Mangold I. Alles Spione. Die österreichische Autorin Anna Kim hat einen raffinierten historischen Roman über den Kalten Krieg in Korea geschrieben: "Die große Heimkehr". ZEIT online. 30.03.2017. URL: https://www.zeit.de/2017/12/anna-kim-die-grosse-heimkehr-roman

12. Migration und Interkulturalität in neueren literarischen Texten. [Hrsg. A. Bliuomi]. München, 2002.162 S.

13. Reeg U. Autor/innen aus dem asiatischen Kulturraum. Interkulturelle Literatur in Deutschland. Ein Handbuch. Weimar, 2007. S. 263-273.

14. Schmitz H. Einleitung. Von der nationalen zur internationalen Literatur. Von der nationalen zur internationalen Literatur. Transkulturelle deutschsprachige Literatur und Kultur im Zeitalter globaler Migration. Amsterdamer Beiträge zur neueren Germanistik. Amsterdam; NY, 2009. S. 7-15.

\section{Information about the author:} Pomohaibo J. O.

Candidate of Philological Sciences, Assistant Professor,

Department of Foreign Literature, Odessa I. I. Mechnikov National University 2, Dvoryanska str., Odessa, 65082, Ukraine 


\section{AUTHOR'S CONCEPT OF SELF-CONSCIOUSNESS IN THE NOVEL "THE ENDLESS DEADLOCK" BY DMITRY GALKOVSKY}

\section{Shtepenko O.}

\section{INTRODUCTION}

At the end of the $20^{\text {th }}$ century, the literary process is distinguished by a special intensity of self-determination and tends to be highly dramatic, to have deep philosophical context, to revise cultural and historical guidelines and literary hierarchies. Writers deeply experience cultural and worldview revolutions, which require the master of words to define his own position. Reflection of the end of the "thaw", internal collisions while formation and resistance to officialdom in the era of "stagnation" and the realization of a complete change in the social and cultural realities of the 1990s stimulated an interest in the problems of creativity precisely in the context of global philosophical issues and led to the emergence of a wide range of selfidentification models. All these features gave the impetus for in-depth selfreflection and reassessment of the entire set of previous models of creator's self-identification, as well as accelerated the dynamics of these processes and intensified their inconsistency.

In-depth self-reflection is imposed on the general tendency of literature to self-comprehension, encourages the search for identity, dialogue with other generations and metatexts of different periods. Therefore, the intention to self-determination gains scale and takes on specific features in the work of different generations precisely under the conditions of fundamental changes at the end of the $20^{\text {th }}$ century. M. Abasheva qualifies them as a search probe for new ideas and forms in the radically changed art of words, as “... a field of various aesthetic experiments on which new models of writing behavior are produced" .

In Russian literature of the late $20^{\text {th }}$ century, it is difficult to find a work of art that could be compared to D. Galkovsky's famous postmodern hypertext "The Endless Deadlock" in breadth of understanding of selfconsciousness. The work provides a concept for discussion, aimed at

1 Абашева М.П. Литература в поисках лица (Русская проза конца XX века: становление авторской идентичности). Пермь: Изд-во Пермского университета, 2001. 320 c. - C. $37-38$ 
awakening the reader, providing a keen dialogue with artistic and philosophical traditions, which is an original, experimental form of metaprose at the same time. It reflects the brightest features of the generation of consciousness.

The relevance of the study and interpretation of D. Galkovsky's hypertext from the perspective of self-reflection of literature is caused by the dominant theme of self-consciousness in this work, which covers a wide material of cultural self-determination of generation and individual. As already stated by the researchers, D. Galkovsky's novel is "a reflection of Russian culture (and especially literature) and the tragedies of national history supposedly caused by it, as well as the narrator's self-interpretation as a typical product of this particular culture and a certain segment of this tragic history",

In our opinion, the author is faced with a supertask - to model a bridge between the cultural identity of different periods - especially the Silver Age and modern times. This is declared from the first pages of the novel: «У каждой нации должна быть ращиональная сказка, охватывающая плотным кольцом все стороны быта и изгибающая их по направлению $\kappa$ иентральному мифу <...>. Мне нужно было высветить реальность новой сказкой, новой актуализаичей русского мифа» ${ }^{3}$.

The innovative intentions of the novel are highlighted in the monographs by R. Nefahina ${ }^{4}$, L. Shevchenko, G. Merezhinska ${ }^{6}$, N. Bieliaieva ${ }^{7}$ L. Sadykova ${ }^{8}$, I. Skoropanov ${ }^{9}$. Modifications of

2 Мережинская А.Ю., Коминарец Т.В. Русская постмодернистская литература конца XX - начала XXI века: знаковый код и стратегии художественного поиска. Херсон: Айлант, 2007. 220 с. - С. 65

${ }^{3}$ Галковский Д. Бесконечный тупик (Основной текст) // Бесконечный тупик: в 2 кн. издание 3-е, исправленное и дополненное. М.: Издательство Дмитрия Галковского, 2008. Кн. 2. С. 2.

4 Нефагина Г.Л. Русская проза второй половины 80 - начала 90-х годов $\mathrm{XX}$ века:учебное пособие для студентов филологических факультетов. Минск: Издательский центр «Экономпресс», 1998. 231 с.

5 Шевченко Л.И. Русская проза трех последних десятилетий (70-90-е годы XX столетия). Kielce: Academii Swietokzyskiey, 2002. 295 с.

${ }^{6}$ Мережинская А.Ю. Художественная парадигма переходной культурной эпохи. Русская проза 80-90-х годов XX века: Монография. К.: ИПЦ «Киевский университет», 2001. $433 \mathrm{c}$.

7 Беляева Н.В. Поэтика маски в русском романе: интертекстуальные аспекты // Русская литература. Исследования. Сб. науч. трудов. Вып. VI. Киев: Логос, 2004. С. 38-53.

${ }^{8}$ Садыкова Л.В. Особенности диалогизма в русской эссеистике рубежей XX века // Русская литература. Исследования: Сб. научн. тр. Київ, 2008. Вып. ХІІ. С. 276-290.

${ }^{9}$ Скоропанова И.С. Русская постмодернистская литература. М.: Флинта: «Наука», 2007. $608 \mathrm{c}$. 
postmodernism, the originality of the "Russian version" and features of the late stage of its dynamics are emphasized in the works of the mentioned literary critics.

However, the novel “Endless Deadlock” by D. Galkovsky has not been consistently considered in terms of self-consciousness and identifying strategies for self-reflection, as well as in the aspect of the author's concept of personal and national consciousness. Therefore, we choose it as the main guideline of our reflections and observations and make an attempt to solve this particular problem.

\section{Specificity of generational consciousness in the novel}

In his work, the writer focuses on the artistic study of the process of self-consciousness and treats it as very painful and dramatic. One may argue the emergence of such accents by experiencing a crisis, transitional state of society and culture. Reflecting on the state of modern man, the narrator compares it with a hermit crab, who has lost his old carapace and is frantically looking for a new one. The carapace, of course, means a system of solid landmarks that disappeared in a situation of social and philosophical cataclysms of the late 1980s and early 1990s. Personal and general cultural aspects of the artistic study of consciousness turn out to be closely intertwined, and the specificity of generational consciousness is expressed clearly in the process of self-reflection.

D. Galkovsky was born in 1960 and formed as a personality, philosopher and writer in an atmosphere of "stagnation". He creates a phenomenal artistic image of this period as a fatal, infernal spell that has created a specific worldview worthy of artistic and scientific interpretation. In the essay "Endless Deadlock (Main Text)" this period is characterized as "twilight". But it extends its scope to the entire $20^{\text {th }}$ century. The aesthetic approach to the terrible, a kind of "decadent" accent, reveals clearly. The writer tries on a mask of aesthetic decadent, experiencing "fatal minutes" and finds beauty in a disaster: «Я живу в эпоху сумерек. В конце прошлого века очень боялись этого слова. Казалось, что это что-то страшное, багрово-красное, как бы преддверие ада: сумерки сознания, сумеречное сознание. Но сумерки - это совсем не страшное, а красивое слово. Набоков сказал: "Сумерки - это такой томный сиреневыци звук" ${ }^{10}$. In the novel, the seemingly marginal years of "stagnation", which lose in the external dynamics to a fractured "thaw",

${ }^{10}$ Галковский Д. Бесконечный тупик (Основной текст) // Бесконечный тупик: в 2 кн. издание 3-е, исправленное и дополненное. М.: Издательство Дмитрия Галковского, 2008. Кн. 2. С. 1170. 
are characterized as «изюминка нашей эпохи» ${ }^{11}$. They are conceived as a time of internal not an external action, the maturation of selfconsciousness, the most auspicious period for self-absorption and setting the problem of personal and national identity. Looking at the entire Soviet era with its totalitarian suppression of man, D. Galkovsky finds either an obscureness, a specific darkening in the 1960-1980s, or an assessment of only external phenomena without clarifying the inner, hidden essence of the spiritual life of this period: «Писалось $u$ пишется об экстравертированных ужасах. A есть еще ужасы интровертированные, в реальности не видные. И это страшней. Как раз 60-80-е это преимущественно эпоха интровертного инферно. Предырущие поколения до него просто не дорастали, не дожсивали. Голод, войнь, эпидемии - тут не до психологии. Личная жизнь, “я" человека не дорастали до нужного уровня, не окунали свой мозг в холодное верхнее злорадство. Это сейчас только разгорелось» ${ }^{12}$. However, according to the narrator of the novel, the opportunity to comprehend the "basic questions of being" was realized in the 1960s early 1980 s in an ugly form and under the pressure of the wrong mechanisms of socialization. D. Galkovsky, immerses himself in autobiographical material and creates a self-parody: an unfortunate, noone-needed "genius" - Odinokov. The author focuses on the distortions of Soviet pedagogical concepts, forcible collectivism, the persecution of lone wolves who stand out from the rest, mania for "reforging" and "reeducation". While in the West they sent peculiar children to a psychotherapist, in "stagnant" Russia "such" get kicked: «Чmo же, абстрагируешься от коллектива? < ..> Бейте его, ребята!!!" < ..> Математикой занимается? - Не гармонично! Пускай рисует. $A$ этот, что рисует? - $B$ математику его. <...> Главное, чтоб гармонично. Чтобы человека можно было, как гармошку, растягивать и сокращзать» ${ }^{13}$.

The writer creates his myth about the 1960s - 1980s, his contemporary and contemporary's self-consciousness. In the context of such a meta-

${ }^{11}$ Галковский Д. Бесконечный тупик (Основной текст) // Бесконечный тупик : в 2 кн. издание 3-е, исправленное и дополненное. М.: Издательство Дмитрия Галковского, 2008. Кн. 2. С. 890.

${ }^{12}$ Галковский Д. Бесконечный тупик (Основной текст) // Бесконечный тупик : в 2 кн. - издание 3-е, исправленное и дополненное. М.: Издательство Дмитрия Галковского, 2008. Кн. 2. С. 890.

13 Галковский Д. Бесконечный тупик (Основной текст) // Бесконечный тупик: в

2 кн. издание 3-е, исправленное и дополненное. М.: Издательство Дмитрия Галковского, 2008. Кн. 2. С. 891. 
narrative, this period is interpreted as the climax of socialism (the achievement of its peaceful utopia), a hell that absorbed the features of specific decades and, at the same time, a lull that allows the individual to understand fundamental issues, that is, a gracious time.

Inferno forces aim at destroying any individual and turning over the picture of the world, reflecting the peaks of culture in a dark mirror (for example, substitutes with opposite potential immerge in the place of geniuses, signs of culture: instead of Leonardo da Vinci and Goethe there is the socialist version of thinkers and creators).

Experiencing such a period in the subtext is compared with passing through hell, with the extraordinary initiation, the realization of a fabulous impossible task, the battle with the infernal enemy. All these mythological landmarks are part of the author's idea of himself and the generalized contemporary.

There is a clear author's focus on the mythologization of the Soviet period (and especially its utopian peak - "stagnation"), on searching some archetypal foundations in the realities of the ideological life. The axis "sacral / infernal", as well as "harmonious, integral / deformated, split" appear in this process. The following model arises: the fatal events of the Revolution destroy the old cosmos, and the new one is constructed as distorted, reduced and travesty. An example of such a conversion realizes, in particular, in the reflections on the "Soviet religion". Therefore, Absolute, philosophical aspect of the world is chosen as the criterion for assessing the distortion, the inversion of the world: «Новый строй возник как расстройство, как хаотичное разрастание отдельных фрагментов разрушенного мировоззрения. Так аскетический идеал был воспринят как идеал духовного обеднения, а русской душе, веками настраиваемой на монастырь, примитивная пуританская демагогия нашла свой архетипический резонанс. Такая же обморочность, переплетенность пророческих развалин характерна и для других аспектов советской религийки. Если мощнье ствольи великих религий вырастали естественно, создаваясь тысячелетиями, и очень органично включались в душу человека, необычайно усиливали и облагораживали ее, то советская религия - это бутафорское древо, собранное из засохших веточек спиленного христианства» ${ }^{14}$.

The generational aspect of the problem of self-consciousness organically combines personal and general cultural principles. According

14 Галковский Д. Бесконечный тупик (Основной текст) // Бесконечный тупик: в 2 кн. издание 3-е, исправленное и дополненное. М.: Издательство Дмитрия Галковского, 2008. Кн. 2. С. 920. 
to the narrator, the whole post-October period, and the "introverted inferno" of the 1960s-1980s in particular, leads to the fatal slowing-down of national consciousness, threatened to fade away in the "twilight dream".

But the experience of the narrator and Odynokov as his defamiliarized alter ego is intended to show the opposite: strong personalities manage to understand themselves and time in a broad philosophical context deeper than "fathers" and "grandfathers" and thus approach the cultural peak of the Silver Age, its broken tradition.

Passing such a test of chaos and deformity is explained by the hero (a man of the 1970s-1980s) as the initiation and choice of several paths at the existential intersection. The results of such initiation are interpreted in a range of contrasting, antinomic possibilities.

The first position is death ("<..> все было рассчитано на мое унижение и уничтожение. Вот где сатанинский, античеловеческий характер нашего мира <..." $)^{15}$. We may consider deformity of personality as variation of death. And the narrator exclaims not without play and coquetry: «А так кто я? - Ублюдок» ${ }^{16}$ ], knowing that the whole work, its philosophical depth and aesthetic organization refute this selfhumiliation, make it interpreted as foolishness, argumentum a contrario.

The second possibility is the maturation of abilities despite all the infernal forces of "stagnation". Actually, the work aims to prove it.

And finally, in the comments, which are compositionally close to the ending, a third, positive, possibility of initiating by "stagnation" is formulated. It consists in becoming a winner. This self-identification is based on a generalization of personal experience and correlates with the philosopher K. Leontiev's considerations about the ordeals caused by the coming socialism. «Если Леонтьев не знал, что же может утешить грядущего нового человека; “аскета", у которого будет отнята религия с идеей вечного блаженства, то повествователь с учетом приобретенного исторического и культурного опьта констатирует: “Зато мы узнали. Мbl, победители. (А ведь действительно

15 Галковский Д. Бесконечный тупик (Основной текст) // Бесконечный тупик: в 2 кн. издание 3-е, исправленное и дополненное. М.: Издательство Дмитрия Галковского, 2008. Кн. 2. С. 891.

${ }^{16}$ Галковский Д. Бесконечный тупик (Основной текст) // Бесконечный тупик: в 2 кн. издание 3-е, исправленное и дополненное. М.: Издательство Дмитрия Галковского, 2008. Кн. 2. С. 891. 
победители. Тот, кто остался жить после “пира богов”, победитель)» ${ }^{17}$.

The author gives hopes for a possible revival. However, the revival interpreted from the religious point of view (in contrast to infernal motives) is not declared but problematized. Moreover, deformities of the personality, caused by "stagnant" period and its ugly programs, are declared again: «Речь идет, таким образом, о религиозном возрождении. Для меня, как личности, этот путь невозможен. В конечном итоге я смогу прийти в ичерковь, но куда же мне девать мое детство, лишенное светльх образов религиозного опьта, этой основы православия? Или кто мне вернет мою юность с ее сложной и запущенной душевной жизнью, но жизнью совершенно вне категорий любви? Вообще, как мне вместить разросшееся мышление под иерковный купол, если душа моя искажена, деформирована, просто во многом инфантильна, недоразвита?»18. However, recognition of these deformities does not abolish revival, but transfers it to another sector of culture: from religious to creative (artistic and philosophical). It is no accident that a "writer" is the last selfdetermination.

At the same time, the main story is the search for identity, a meaningful process of cultural consciousness. The difference in the interpretations of the widest range of phenomena becomes the mainspring of the internal action: from literary discoveries and images to historical events, philosophical concepts and political processes. The narrator proceeds from the statements of philosophers, literary images, his reflections after all, and creates commentaries on them, where he develops or makes paradoxical the ideas from the primary sources, brings them to absurdity, demythologizes them. His evidence is also not flawless and may be counter-reflective. Odynokov's world-view deformations are comprehended as typical, generated by the times of an "introverted inferno" and peculiar to the entire generation formed in its context. It is implied that precisely this generation has the mission to form consciousness in its personal and national coordinates and, therefore, to win and promote cultural revival.

${ }^{17}$ Галковский Д. Бесконечный тупик (Основной текст) // Бесконечный тупик: в 2 кн. издание 3-е, исправленное и дополненное. М.: Издательство Дмитрия Галковского, 2008. Кн. 2. С. 914.

${ }^{18}$ Галковский Д. Бесконечный тупик (Основной текст) // Бесконечный тупик: в 2 кн. издание 3-е, исправленное и дополненное. М.: Издательство Дмитрия Галковского, 2008. Кн. 2. С. 920. 


\section{Characteristic features of the process of self-reflection in D. Galkovsky's hypertext}

Let us trace the features of the process of self-reflection, its relation to philosophical problems in the literary text "The Endless Deadlock".

D. Galkovsky represents the process of self-reflection, firstly, as the realization of a philosophical type of thinking and, secondly, as a feature of national consciousness, its desire to "speak out" and define its borders, stable supports. These theses are not declared, but are often directly proved by the opposite, which corresponds to the postmodernist way of playing the fool. In the novel, this idea is explained as follows: «Следовательно, Набоков отказался от самопознания. Человек в высшей степени способный $\kappa$ самопознанию, он никогда не поставил в иентр повествования самого себя. Его мемуары чисто внешние, описательные. Он отшатнулся от себя. Россия потеряла гениального философа, но приобрела счастливого человека. Ведь судьба Набокова максимально счастлива для русских его поколения» ${ }^{19}$. The opinion is expressed in a provocative manner, but it becomes a part of the system of proofs of the author's approach correctness and contrasts with the recognition of V. Rozanov (the author of "Solitaria" and "Fallen Leaves", aimed specifically at the self-discovery) as the first true Russian philosopher, as well as the discoverer of this subject. D. Galkovsky consistently identifies himself as V. Rozanov's student, armed with the aim of defining the pillars of personal and national consciousness. Literary analysis of artistic thinking dominates among many aspects of consideration of the problem (such as historiography, history of Russian philosophy in the context of the world philosophy, conspiracy, imagology).

A wide range of ideas about creativity is exposed to self-reflection in the novel. Creativity is described as a mystical act, the closest one to the mystery of the world creation and man's fate. It results in the constant replacement of positions on the scale from the author to the hero, because the haughty writer (it is V. Nabokov in the following passage), who masters the hero's life, is himself a work. Moreover, the hero of the novel can acquire mystical autonomy and, unexpectedly for the author, to parody his creator, to hint at the existence of incomprehensible interdependencies of these figures. That is why, according to D. Galkovsky, the problem of creativity is philosophical and can be considered, but not solved within the

19 Галковский Д. Бесконечный тупик (Основной текст) // Бесконечный тупик: в 2 кн. издание 3-е, исправленное и дополненное. М.: Издательство Дмитрия Галковского, 2008. Кн. 2. С. 671. 
relevant discourse. The quoted commentary is a response to V. Nabokov's words about the pleasure of modelling Luzhin's fate, inventing its fatal turns, "playing subtly and ingenious" with it: «Но насколько его герой является его героем? Не есть ли все его поведение - борьба с автором и сюжетом? В сущности Лужин догадывается о сюжетности и предумышленности своей жизни. Но, конечно, догадка не может быть ничем иным; его хаотическая "борьба" лишь прихотливый изгиб сюжетной линии. Автор могуществен. Но, с другой стороны, автор же и конечен. Он сам Лужин по отношению к некоему подлинному Автору своей жизни. Произведение-то теологическое, философское. Это есть свобода воли и как она сочетается с божественным предопределением. И не умозительнотерминологически, а реально. <... К Как это могло бы быть при реальности существования Высшего мира. И в какой степени человек может догадываться о возможности такового. Не в той ли, в какой Лужин догадывался о существовании Набокова?» ${ }^{20}$. Throughout the novel, Odinokov repeatedly compares himself to Luzhin, looking for differences, already acknowledging the similarity in advance. The author models Odinokov's image upon literary patterns, acknowledges that his thinking is "literary", seeks for a higher meaning and logic in his destiny by addressing the Higher world (problems of religion, mystery of words, human nature, mysteries of personal and national consciousness).

Literature displace the "meaning of life" provocatively. A lot of transformations and substitutions occur: the author turns into Odinokov, who, in turn, tries on the masks of different literary heroes. One's own life is read from the perspective of literature, which raises the question of the possibility to find an identity in general, exacerbates the postmodern "death of the subject", the fundamental "secondaryness" of the individual, his dependence on cultural texts, the ineffability. The following provocative reflections of the narrator may serve as an example: «Случилось самое нелепое. Я превратился в романтического героя, в обычного, заурядного гения. Моя биография архаична, да и просто является штампом: "гениальный одиночка, изгой, стоящий в костюме арлекина посреди зачумленного города и хохочущий смехом сатанинским". Но каково мне, когда эта пошлятина (а для русского сознания это всегда будет пошлятиной) вдруг оказалась моей

${ }^{20}$ Галковский Д. Бесконечный тупик (Основной текст) // Бесконечный тупик: в 2 кн. издание 3-е, исправленное и дополненное. М.: Издательство Дмитрия Галковского, 2008. Кн. 2. С. 663. 
судьбой. Если так все по нелепым книгам выщло» ${ }^{21}$. One's own image, which is based on literary models, is doomed not only to be secondary but also to become a parody, stylization or travesty of an authoritative model. And we can trace the "mockery" of the individual on the part of the process of self-knowledge and language. Mockery turns to be the answer, as Odinokov demythologizes and brings down to earth authoritative figures that claim power over the world. Accordingly, the images of Vl. Solovyov, M. Berdyaev, A. Chekhov are desacralized, Familiar relations are established with beloved V. Rozanov, who is re-sacralized and relocated in the centre of Odinokov's worldview: «Где-то посередине, где-то между низменной и вечной сущуностью (будь то дьявольской или божественной» ${ }^{22}$.

The miserable self moves in a circle of literary images and iconic figures, its autobiographical experience, terrified by the inability to escape from this coordinate system. And one of the interpretations of the symbolic title of the novel breaks through in this - the danger of not going beyond the walls of one's interpretations, of being stuck in the process of describing, writing, inventing one's "life story", making the guidelines literary.

The philosophical question of the possibility of personality transcending and the strategies for this process is practically raised. By the way, this feasibility of a qualitative leap forward is considered both in relation to the hero's consciousness and as the form of hypertext, which is threatened by repetition, loss of meaning, loss of reader's interest: «Катастрофа «Бесконечного тупика». Одиноков превращается в бесиельную стилизаџию, идиотски обыгрывающую собственную гениальность. А Соловьев, Черныпевский, Ленин, Набоков, Чехов и др. оборачиваются лишь двойниками моего «я». Вещии оживают и превращуаются в персонажи, персонажи оборачиваются людьми, люди же оказываются на поверку лишь автономными элементами моего «я». «Бесконечный тупик» превращается в тысячестраничную схему, лишенную конкретного содержания. Не так ли?» ${ }^{23}$.

${ }^{21}$ Галковский Д. Бесконечный тупик (Основной текст) // Бесконечный тупик: в 2 кн. издание 3-е, исправленное и дополненное. М.: Издательство Дмитрия Галковского, 2008. Кн. 2. С. 1023.

${ }^{22}$ Галковский Д. Бесконечный тупик (Основной текст) // Бесконечный тупик: в 2 кн. издание 3-е, исправленное и дополненное. М.: Издательство Дмитрия Галковского, 2008. Кн. 2. С. 1033-1034.

${ }^{23}$ Галковский Д. Бесконечный тупик (Основной текст) // Бесконечный тупик: в

2 кн. издание 3-е, исправленное и дополненное. М.: Издательство Дмитрия Галковского, 2008. Кн. 2. С. 1016. 
The problem is resolved paradoxically, in D. Galkovsky's manner of thinking. The very search process turns to be a transcendental strategy. This is because fundamental philosophical questions (including selfdetermination) do not have definitive answers, but the path to solution invariably elevates a man. This opportunity to escape in the act of selfdiscovery, to rise above the whirligig of samples and somebody else's quotes, distinguishes Odinokov from the heroes he provocatively identifies himself with: «Я Лужин, но со странной особенностью - я играю не в шахматы, а в жизнь. Свои собственную жизнь. Моя специализация я сам. Я Лужин, вполне понимающий и осознающий себя Лужиным $<\ldots>$ Но у набоковского героя разрыв с собой, возможная трансформачия своего дара и, следовательно, хоть какая-то компенсачия, обнаруживаемость из реальности. Мой же дар никак не проявляется в мире, он абсолютен и невинен. Лужину этого не надо. Он не замечает себя, и ему важен выигрыш как таковой. Но мой вылгрыши - это сны и, чтобы сны вылграли, нужно их шарлатанское признание» ${ }^{24}$.

Not only the autobiographical hero, but also the historical figures are subject to "becoming literal". Mainly, a grotesque image is created and the effect of paradox, defamiliarization and travesty is modelled. For example, V. Rozanov (beloved by the author) unexpectedly puts on the mask of a character from M. Gogol's "Marriage" in the narrator's reflections about Russian eros. «Розанов - это просто женившийся Подколесин. Подколесин, так и не выпрыгнувший из окошка. Подколесин - Гоголь выпрыгнул (все-таки действительно, "русский народ смельий")»". A rather broad and paradoxical spectrum of possible landmarks of selfidentification and literary "roles" for iconic figures is considered. This game is often based on a serious implication, characterizing the change of cultural epochs, the conditions in which D. Galkovsky's generation was formed.

In the manner of D. Galkovsky, the philosophical problem "becomes literary", i.e. it finds its plot. In this case, it is a "twinning" plot: Vl. Solovyov, V. Rozanov and Odinokov appear in complex mutual reflections. Odinokov searches for his ideal, he looks with envy at the externally beautiful figure of Vl. Solovyov. But the narrator interprets

${ }^{24}$ Галковский Д. Бесконечный тупик (Основной текст) // Бесконечный тупик: в 2 кн. издание 3-е, исправленное и дополненное. М.: Издательство Дмитрия Галковского, 2008. Кн. 2. С. 676.

${ }^{25}$ Галковский Д. Бесконечный тупик (Основной текст) // Бесконечный тупик: в 2 кн. издание 3-е, исправленное и дополненное. М.: Издательство Дмитрия Галковского, 2008. Кн. 2. С. 632. 
Solovyov as a temptation, an unsuccessful romantic sample, whose archetype is carried in other heroes' souls and who embodies their dream about themselves. His image represents the dark side of V. Rozanov and Odinokov' nature: «Он отказался от своего человеческого. Да я сам бы от него отказался. Только оно и слушать не захотело. Тут издевательство несльханное. Я мечтал о несчастной любви, а ее не было. В этом-то и сакральное восхищение Соловьевым у Розанова. Он любил в Соловьеве неудавшуюся высокую часть своего “я". "Блестящую, холодную и стальную". Но это-то и отталкивало Василия Васильевича. Отсюда "демонизм" Соловьева, то есть нечто величественное и одновременно чужое, темное. Розанов оплакивал свою юность и чувствовал, что плакать-то нечего. Ничего не былло» ${ }^{26}$.

Failure (V1. Solovyov's loss of human form, double hysterics) multiplied by failure (impracticability of dreams of V. Rozanov and Odinokov) gives an unexpected positive result - the fruitfulness of the search, the healing nature of self-knowledge, the transcension over the samples, the feeling of a new level of freedom. The achievement of such result is, in our opinion, the purpose of the novel.

\section{Artistic strategies for the self-consciousness process and for creation of the author's myth about creativity}

In the novel, special attention is paid to the dramatic nature of the process of self-consciousness, to the elaborate system of artistic strategies for its depiction. Let us highlight some dominant ways of artistic interpretation.

They include the already mentioned whirling of thought, rotation of the same landmarks in the plane, as well as in the "deadlocks" of subjective evaluations. A situation of mocking turnover of self-consciousness is created: «Обознатушки-перепрятушки». Я говорю только о себе. Даже в отие - я сам. О мире я сужу по «я» философов и писателей, об их «я» по тем же людям, которых я знал <..> о них, в свою очередь, по своей биографии; наконеи, о себе, как о «я», которое является миром, - по книгам, написанным этими же самыми философами и писателями. Это бесконечный тупик» ${ }^{27}$.

${ }^{26}$ Галковский Д. Бесконечный тупик (Основной текст) // Бесконечный тупик : в 2 кн. издание 3-е, исправленное и дополненное. М.: Издательство Дмитрия Галковского, 2008. Кн. 2. С. 668-669.

27 Галковский Д. Бесконечный тупик (Основной текст) // Бесконечный тупик: в 2 кн. издание 3-е, исправленное и дополненное. М.: Издательство Дмитрия Галковского, 2008. Кн. 2. С. 1022. 
The next strategy is to demonstrate the parody of the self-discovery process, exacerbation of the problem of authenticity / imitation, unoriginality. Odinokov gives himself a symbolic definition: $"<\ldots>\Omega$ пародия мыслящаяя»" ${ }^{28}$, and creates allusions to B. Pascal's "roseau pensant". There is a constant balancing act between the parts of the mentioned opposition, and even their overturning. In addition, a double parody is modelled, which creates the effect of seriousness: «Расшифрованная пародия, пародия, осмьсляющая себя как пародию, исчезает $\rangle^{29}$. It results is a feeling of tragedy and high points of view of the self-discovery process. His decision is brought to the absolute and utmost philosophical abstractions, crossing the boundary of personal selfdetermination. The self-replicating chain of parodies reaches the Absolute, becomes a "parody of the infinite" and turns over again, carnivalically falling to zero: «Но чем сложнее, чем грандиознее, тем внутренний смысл моего собственного существования становится проще и

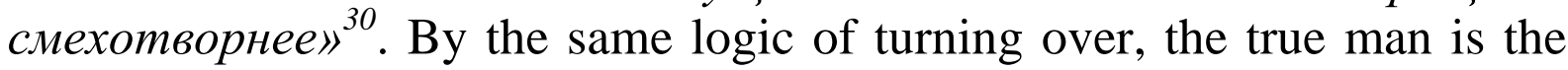
one who reflects his own parody. The narrator finds an example of such self-interpretation in V. Rozanov, who was ironical towards himself, doubted his own authenticity, and therefore was real and did not play somebody else's role. A similar program is inherited by Odinokov.

An important strategy is to single out contrasts and oppositions, to test any program or pattern from the opposite. For example, the novel contrasts examples of successful self-identification with unsuccessful projects. The former include V. Rozanov, while the latter embrace A. Biely, V1. Solovyov, A. Chekhov, and even V. Nabokov, who allegedly abandoned self-reflection. So let us give a provocative interpretation of the figure of Andrei Biely, who seemed to be lost in his own fantasies and could not self-determine: «Космос Белого не создан до кония, не замкнут и расширяется в ноль. Распускается в ничто. Нет каркаса материальных нитей - Бельй не творец, он не мог осуществить свою программу, да и сама программа его проскакивает в бесконечность. Он испортил себя философией, самый "философский" русский писатель (говорил: "я отравлен Кантом"). Нарушение меры

${ }^{28}$ Галковский Д. Бесконечный тупик (Основной текст) // Бесконечный тупик: в 2 кн. издание 3-е, исправленное и дополненное. М.: Издательство Дмитрия Галковского, 2008. Кн. 2. С. 1033.

${ }^{29}$ Галковский Д. Бесконечный тупик (Основной текст) // Бесконечный тупик: в 2 кн. издание 3-е, исправленное и дополненное. М.: Издательство Дмитрия Галковского, 2008. Кн. 2. С. 1033.

${ }^{30}$ Галковский Д. Бесконечный тупик (Основной текст) // Бесконечный тупик: в 2 кн. издание 3-е, исправленное и дополненное. М.: Издательство Дмитрия Галковского, 2008. Кн. 2. С. 1033. 
по сравнению с Розановым и Набоковым, и в результате несчастная пародийная личность и судьба» ${ }^{31}$. Undoubtedly, any vague interpretations are also the self-characteristics of Odinokov. They contain his idea of the unsuccessful self-knowledge, the reflection of negative alter ego and fear of repeating a mistake or tragedy. These are all mirrors that reflect the hero.

As a result, a model of the hero is created. The following systemforming features characterize it. Firstly, it is a philosopher and writer who tries to identify the support of personal and national consciousness, and who reconsiders established models and authorities. Self-reflection is the most significant feature. It is considered as a process of philosophical comprehension of the whole world, since it is a set of interpretations in subjective reflection. Such character constantly resorts to self-reflection, provocatively evaluates it as a flaw, but interprets it as a productive process that facilitates the rise and transcendence in subtext: «B моей жизни есть органический порок, дефект. Какая-то исключительная глупость таится во всем, что происходит со мной. Какую-то я в своей жизни роковую ошибку допустил, что самое обидное - уму моему не доступную, непонятную <...> Может быть, и ошибка-то как раз в этом ощущении ошибочности своей жизни» ${ }^{32}$. This person is completely subjective, reserved and literarycentric, inclined to self-parody and stylization («Все исчезает в стилизации», «Попьлтка самосознания грозит превратиться в жеманную стилизацию» $\left.{ }^{33}\right)$. Romantic hero, underground man, "superfluous man", "little man", Luzhin, V. Rozanov, V. Nabokov are selected as models for stylization.

Odinokov acts as an aesthete, close to modernist traditions. He clearly sympathizes with V. Nabokov's aristocracy. Emphasizing this feature in a favourite writer's appearance is an element of self-reflection, selfcharacterization. Aestheticism is interpreted paradoxically: the most distant principles - aristocracy and democracy - are integrated: «Набоков был самым демократичным русским писателем. Его демократичность a аристократизме, в постоянном подчеркивании элитарного характера художественного творчества. Рассматривая весь мир

31 Галковский Д. Бесконечный тупик (Основной текст) // Бесконечный тупик: в 2 кн. издание 3-е, исправленное и дополненное. М.: Издательство Дмитрия Галковского, 2008. Кн. 2. С. 1024.

32 Галковский Д. Бесконечный тупик (Основной текст) // Бесконечный тупик: в 2 кн. издание 3-е, исправленное и дополненное. М.: Издательство Дмитрия Галковского, 2008. Кн. 2. С. 1023-1024.

33 Галковский Д. Бесконечный тупик (Основной текст) // Бесконечный тупик: в

2 кн. издание 3-е, исправленное и дополненное. М.: Издательство Дмитрия Галковского, 2008. Кн. 2. С. 1020. 
через призму этой элитарности, он одновременно подчеркивал органичность подобного подхода к миру» ${ }^{34}$. At the same time, such close aestheticism inverts and start being evaluated as a pose, theatrical, outer form that covers the void. This quality extends to the national mentality unexpectedly (the constantly repeated Rozanov's definition of Russian as "nonsense with art"). It defamiliarizes the natural artistry, inner self-absorption and the tendency to fantasies. The subtext of the novel "Crime and Punishment" is also waved into the reflections: Raskolnikov's question «Человек я или тварь дрожащая?» is replaced by a phrase, which is more interesting than the constantly quoted «тварь»: «Э $x$, эстетическая я вошь, и больше ничего» ${ }^{35}$.

The hero acts as a pure introvert, who differs from the "underground man" by his declared and well-grounded "genius", while the problem of relations between the outer and inner worlds is exacerbated to the limit. Absolute primacy is given to the inner world. ("Тот же Набоков сказал: "Внешние впечатления не создают хороших писателей, хорошие писатели сами выдумывают их в молодости, а потом используют так, будто они и в самом деле существовали”. Выдумка может быть гениальной и может почти полностью заменить реальный onblm» $^{36}$ ). The contrast between the hero's perception in these coordinate systems is modelled. He is a genius and a creator in the inner world and a bored marginal weirdo in the outer world.

The dramatic clash of worlds and roles, the unresolved conflict gives birth to the author's myth. Traditional structures, fairytale and literary implications are involved in this myth. For instance, Odinokov is in the fantasies and dreams of his own world, like a sleeping beauty, or Hamlet, who has fallen asleep and sees dreams: «Я создан совсем для иной, обычной жизни. Внешне совсем обычной, а внутренне абсолютно фантастической, высшей. Настолько высшей и светлой, что сон станет бытием, а быт сном. И внешне это будет совсем незаметно, совсем не страшно. Хотя для окружающих меня уже совсем

${ }^{34}$ Галковский Д. Бесконечный тупик (Основной текст) // Бесконечный тупик: в 2 кн. издание 3-е, исправленное и дополненное. М.: Издательство Дмитрия Галковского, 2008. Кн. 2. С. 638.

35 Галковский Д. Бесконечный тупик (Основной текст) // Бесконечный тупик: в 2 кн. издание 3-е, исправленное и дополненное. М.: Издательство Дмитрия Галковского, 2008. Кн. 2. С. 1028.

36 Галковский Д. Бесконечный тупик (Основной текст) // Бесконечный тупик: в 2 кн. издание 3-е, исправленное и дополненное. М.: Издательство Дмитрия Галковского, 2008. Кн. 2. С. 1020-1021. 
скучно»". Thus, the image of the "destitute", which absorbs and inverts the Block subtexts («О Русь моя! Жена моя...»), traditions of the "superfluous man", biblical subtexts, is modelled. The motives of mockery of the genius become more intensive. Not a crowd, but a cruel, even infernal world mocks him now: «Никто, ни одна не подумала: «мне вот этого», «а, пожалуй, Одинокова возьму» <..> А женскими глазами на меня смотрела Россия. И решила: не надо. И детей от такого не надо. Нет, не только я виноват в своем одиночестве. Я миру этому не нужен. $<\ldots>\gg{ }^{38}$.

The fierce confrontation of the outer world (cruel and totalitarian) and the inner self results in the creation of another myth about the victor, the unconquered one who went through death and survived. It is already a heroic myth that absorbs the model of initiation, the plot of Orpheus, the Easter archetype, which further substantiates the need to find firm foundations of one's self and national consciousness.

\section{CONCLUSIONS}

The Russian literature of the late $20^{\text {th }}$ century is characterized by an intensive process of the self-reflection of literature with a tendency to globality. The leading trend is the combination of the search for personal, cultural and national identities.

D. Galkovsky's prose is the central artistic phenomenon of the consciousness of the literature of the 1980s -2000s. It establishes a high level of artistic study of the process, in which philosophical, artistic, sociological and cultural perspectives are synthesized.

The author's ultimate priority is the synthesis of artistic and analytical types of thinking in hypertext, the unity of philosophical and artistic principles, identified by D. Galkovsky as "philosophical impressionism". It originated in V. Rozanov's and V. Nabokov's works and became the basis of his own author's strategy for the development of a comprehensive world view from the fragments of being through complex associations, reflections in the system of mirrors using the game and style complexity.

Both analytical models of personal and national consciousness and myths about them are created in D. Galkovsky's novel. Search vectors are common in creating these concepts. These are in-depth self-reflection,

${ }^{37}$ Галковский Д. Бесконечный тупик (Основной текст) // Бесконечный тупик: в 2 кн. издание 3-е, исправленное и дополненное. М.: Издательство Дмитрия Галковского, 2008. Кн. 2. С. 1022.

38 Галковский Д. Бесконечный тупик (Основной текст) // Бесконечный тупик: в 2 кн. издание 3-е, исправленное и дополненное. М.: Издательство Дмитрия Галковского, 2008. Кн. 2. С. 698. 
analysis of others' authoritative interpretations, identification of closest figures and forms of self-reflection.

The model of author's self-identification in the work is expressed as follows: the writer and philosopher, who reflects the fundamentals of personal and national consciousness, projects the features of self-reflection in the situation of ideological and aesthetic shifts. Typological features of such model are dramatic and transcendental self-reflection, being literary, aestheticism, elitism. A wide range of literary heroes and historical figures (romantic hero, "underground man", "little man", "superfluous man", Luzhin, V. Rozanov, V. Nabokov) are rethought as models.

The author's myth about himself intertwines contrasting fundamentals and equalizes irreconcilable contradictions: the conflict of romantic genius ("Hamlet who sees dreams", "sleeping beauty", "destitute" with Block subtexts) is put on a par with low reality; the proclaimed marginality and mediocrity are opposed to the archetypes of the victor, harmonious cosmos builder, Adam, who gives names; a cultural hero who rectifies fatal mistakes and facilitates to intertwining the fragmented consciousness.

In fact, such guideline is realized in the dominant author's myth about creativity. It is interpreted as finding the solid foundations of selfidentification, building a harmonious world on their basis (the construction archetype), naming these foundations (like Adam who gives names), rectifying fatal mistakes with the word and facilitating the flowering of a new cosmos.

\section{SUMMARY}

The article concentrates on the study of the controversial authorial concept within the context of understanding of self-consciousness in Dmitry Galkovsky's postmodern hypertext "The Endless Deadlock". This concept combines an original experimental meta-prose with a sharp dialogue of artistic and philosophical traditions and demonstrates synthesis of creative and analytical types of thinking. The interpretation of the novel from the perspective of self-reflection shows the specificity of generational consciousness and embraces dominant strategies for cultural selfdetermination of the individual. The article also examines the model of author's self-identification and defines its typological features (dramatic and transcendental self-reflection, aestheticism, elitism and being literary). Scientific interest is focused on the author's concept of personal and national self-consciousness and on the creation of their analytical models and myths about them in the artistic text. In this combination, the author's myth intertwines the contrasting contradictions of the writer's search for the basics of self-identification of the person and the development of a new model of the postmodern universe based on them. 


\section{REFERENCES}

1. Абашева М.П. Литература в поисках лица (Русская проза конца XX века: становление авторской идентичности). Пермь: Изд-во Пермского университета, 2001. 320 с.

2. Беляева Н.В. Поэтика маски в русском романе: интертекстуальные аспекты // Русская литература. Исследования. Сб. науч. трудов. Вып. VI. Киев: Логос, 2004. С. 38-53.

3. Галковский Д. Бесконечный тупик (Основной текст) // Бесконечный тупик: в 2 кн., издание 3-е, исправленное и дополненное. М.: Издательство Дмитрия Галковского, 2008. Кн. 2. С. 1101-1179.

4. Мережинская А.Ю. Художественная парадигма переходной культурной эпохи. Русская проза 80-90-х годов XX века: Монография. К. : ИПЦ «Киевский университет», 2001. 433 с.

5. Мережинская А.Ю., Коминарец Т.В. Русская постмодернистская литература конца XX - начала XXI века: знаковый код и стратегии художественного поиска. Херсон: Айлант, 2007. 220 с.

6. Нефагина Г.Л. Русская проза второй половины 80 - начала 90-х годов XX века: учебное пособие для студентов филологических факультетов. Минск: Издательский центр «Экономпресс», 1998. 231 с.

7. Садыкова Л.В. Особенности диалогизма в русской эссеистике рубежей XX века // Русская литература. Исследования : Сб. научн. тр. Київ, 2008. Вып. ХІІ. С. 276-290.

8. Скоропанова И.С. Русская постмодернистская литература. М.: Флинта: «Наука», 2007. 608 с.

9. Шевченко Л.И. Русская проза трех последних десятилетий (70-90-е годы XX столетия). Kielce: Academii Swietokzyskiey, 2002. 295 c.

\section{Information about the author:} Shtepenko O.

Doctor of Philology, Associate Professor, Professor at the Department of World Literature and Culture named after professor O. Mishukov,

Kherson State University 27, 40 rokiv Zhovtnya str., Kherson, 73000, Ukraine 


\section{THE RULERS OF EARLY KIEVAN RUS \\ IN T. BABITSKAYA'S STORY "PRINCESS OLGA": \\ LITERARY CONTEXT AND PECULIARITIES \\ OF THE AUTHOR'S INTERPRETATION \\ OF THE SOURCE BASE AND HISTORIOGRAPHICAL \\ EXPERIENCE}

\section{Vysotsky A. A.}

\section{INTRODUCTION}

The era of Kievan Rus, full of dramatic and crutial events, have always fascinated the masters of belles-lettres in Ukrainian and Russian literatures from the $18^{\text {th }}$ century to our time. In the second half of the $20^{\text {th }}$ century in Ukrainian and Russian literatures to the initial period, for example, the period of existence of Russ referred the acknowledged masters of the fiction-historical prose as well as less well-known writers, choosing for their preferences varied plots, characters, genre forms, and the like. Val. Ivanov, S. Sklyarenko, P. Zagrebel'ny, Ant. Ladinsky, Y. Alexandrov, A. Zagorsky, V. Muravyov, S. Ponomarev, Y. Prodan, R. Ivanchenko, S. Voevodin, V. Yavorivsky and others - is not a full list of writers, who appealed to Russ antiquity at different times.

In "old" works of some of the artists the description of the fate of a fictional character was associated with adventure intrigue (historicaladventure novel of I. Kovalenko "Uleb The firm hand" (1978)). In other cases, the lives of the characters and description of epy staged historical periods strongly rely on the information of relevant sources ("Sviatoslav" (1959), "Vladimir" (1962), S. Sklyarenko, "The funeral of Gods" (1986), I. Bilyk). Stories and novels which were written by historians ("Black arrows of Vyatichi" (1977), "Sviatoslav" (1982) of V. Kargalov; "New Sky" of Y. Jejuly (1989)) are interesting because of their informational richness of the historical background. Speaking of the works of the Belarusian literature of the indicated period, one can mention E. Skobelev's novel "Miroslav, Prince of Dregoviches" (1979), written in stylized as "archaic" language, etc. The novels of S. Voevodin ${ }^{1}$ and

${ }^{1}$ Воеводин С. Ратник княгини Ольги: Роман. Х.: Клуб семейного досуга, 2018. 288 с.; Воеводин С. Вещего Олега: Роман. Х.: Клуб семейного досуга, 2019. 256 с. 
V. Yavorivsky ${ }^{2}$ are among the newest books that came to the Ukrainian reader.

It can not be said that the theme "Rus in fiction" refers to the unexplored topics by literary critics as well as by historians. The list of special works (V. Donchyk, M. Slaboshpitsky, V. Fashchenko, V. Oskotsky, V. Chumak, M. Ilnitsky, Y. Bondarenko, O. Kolinka, T. Sushkevich, T. Litvinchuk, V. Kargalov, V. Pashuta and many others) could take more than one page. Of course, the experts-precursors have accumulated considerable biobibliographic material, highlighted the poetic properties of "ancient" works. We would just like to supplement their experience with some considerations regarding the specifics of the writer's interpretation of medieval sources and historical concepts of his and past epochs in the creation of images of the first rulers of Rus, taking into account works that, for one reason or another, have been overlooked by meticulous research attention. The following observations are just approximate sketches that can be used as the subject of special studies (in particular, devoted to identifying the author's aesthetic and moral orientations in comparing present and past, the specifics of understanding traditions in the fictional reproduction of the Rus realm of ancient times, the process of formation of its own artistic manner, renovation of the stylistics of historical prose in the new social conditions, etc.).

\section{Oleg and Olga in T. Babitskaya's story: state-making and personal dimensions of the author's "portraiture" of characters and its literary context}

Soviet and Ukrainian film director Y. Ilyenko did not accidentally name one of his films "The Legend of Princess Olga" (1982). Olga, the Kiev ruler, still remains one of the most mysterious figures in national history. Rus' first female diplomat to outwit the Byzantine emperor; mother of militant Svyatoslav, known by the descendants for his famous "I come against you!"; a stern princess who viciously avenged her husband's death; a humble Christian, who, according to the chronicle, was "the forerunner of the Christian land" - all this is Olga, whose image is tightly wrapped in a flurry of legends. It is not surprising that the life and actions of the princess have attracted the attention of many writers.

The base for Tatiana Babitskaya's story "Princess Olga" (1990) is a chronicle of events of the first half of the $10^{\text {th }}$ century, which are related to

2 Яворівський В. У мене вечеряв Ісус. Княгиня Ольга - велика грішниця, яка стала святою. К.: Брайт Букс, 2019. 344 с. 
the names of the Kiev statesmen Oleg, Igor, Princess Olga. According to the name of the work, its main figure is Olga, who began to rule after the death of her husband Igor in 945. Through the princess' prism of life T. Babitskaya reflects the leading tendencies and processes of the distant epoch, the difficult conditions for the formation of ancient Rus statehood.

Once A.-L. Schlözer lamented: “...there is no information about the origin of this immortal wife (Olga. - A.V), of her birthplace, age, education, and other insignificant circumstances that one would like to know"3. These words have not lost their relevance today. The problem of origin, in particular its social and ethnic aspects, has not been finally resolved. "The Tale of Bygone Years" states that Olga was brought to Куіv "оть Плескова". If the chronicle "Pleskov" is Pskov, then the future princess could be from Krivich genus ${ }^{5}$. Ioakimivsky Chronicle, known to us in V. Tatyshchev's retelling, considers Olga to be a relative of the Prince of Novgorod, also known as mayor of Gostomysl ${ }^{6}$. The anonymous author of Olga's Life (the end of the $17^{\text {th }}$ - beginning of the $18^{\text {th }}$ century) writes about the Varangian origin of Olga, emphasizing the nobility of Olga's family ${ }^{7}$. Olga's homeland was considered an anonymous land by the village of Vybut near Pskov. There is a version about the origin of Olga "from the Varangian people, from ordinary people". "The uncertainty about the origin of Igor's wife and the similarity of the name "Пльсковъ" with the name of the Bulgarian capital Pliska, - wrote M. Brychevsky, gave rise to the assumption that Olga was a Bulgarian princess"9. Among the researchers, one of the most common is the opinion that Olga came from a noble family who lived in Pskov land ${ }^{10}$.

Such divergent thoughts about the origin of the princess could not but affect the fictional concept of her image in historical prose. For example, in S. Sklyarenko's novel "Sviatoslav" Olga mentions her orphan youth in the

${ }^{3}$ Шлецер А.-Л. Нестор. СПб., 1816. Ч. 2. С. 594.

${ }^{4}$ Повість врем'яних літ: Літопис (За Іпатським списком). К.: Радян. письменник, 1990. С. 40.

${ }^{5}$ Брайчевський М. Ю. Утвердження християнства на Русі. К.: Наук. думка, 1988. C. 89 .

${ }^{6}$ Котляр Н. Ф., Смолий В. А. История в жизнеописаниях. К.: Наук. думка, 1990. C. $43-44$.

7 Житіє Ольги. Дерево пам'яті: Книга українського історичного оповідання. К., 1990. Вип. 1. С. 155.

8 Погодин М. П. Нечто о роде великой княгини Ольги. Tpуды и летописи Общества истории и древностей Российских. 1828. Ч. IV. Кн. 1. С. 133.

${ }^{9}$ Брайчевський М. Ю. Утвердження християнства на Русі. С. 89.

10 Пушкарёва Н. Л. Женщины Древней Руси. М.: Мысль, 1989. С. 13.; Котляр Н. Ф., Смолий В. А. История в жизнеописаниях. С. 44. 
Vybutsk region of Pleskov land ${ }^{11}$. The main character of V. Panova's story "The legend of Olga" (1966) is the daughter of the chief of paddlers on the Velyka River near the Vybutsk region of Pskov ${ }^{12}$. If Olga is shown in the V. Kargalov's novel "Sviatoslav" as the daughter of a simple Pskov foreman $^{13}$, then Olga's father in S. Ponomaryov's novel "Thunderstorm above Rus" is a Pskov governor who died while protecting the city from the Germans ${ }^{14}$. And here, in I. Bilyk's novel "The funeral of Gods" HelgaOlga is a daughter of Varangian Oleg, who was married to a Bulgarian prince, and later, for the second time - to $\operatorname{Igor}^{15}$. This series can be continued.

T. Babitskaya models her own concept of the image of Olga, synthesizing data from historical sources, contemporary special researches and drawing on the experience of her predecessors, prose writers. Generally speaking, without deviating from the leading tendency in the hagiographic and historiographic literature, the writer using Olga's mouth states that "вона - дочка псковського воєводи i внучка князя кривичів" $"$. For T. Babitskaya the origin of Olga is not relevant to the concept of the work, as, for example, in I. Bilyk's mentioned novel, whose characters are divided on national grounds into parties at war with each other. If, according to M. Ilnitsky, the leading idea of the "The funeral of Gods" is "to show how the Varangians usurped power in Rus from Rurik to Igor, and how Volodymyr's Rus was liberated from their domination"17, T. Babitskaya seeks to reflect the contradictions and cruelty of a distant epoch when the ancient laws were broken and family members stood against each other (Hotovid storyline).

Our acquaintance with the heroine of "Princess Olga" occurs at the beginning of the story, when the daughter of the Pskov governor Hotobud appears before the eyes of Kiev prince Oleg. The girl expresses such thoughts that the experienced statesman Oleg has only to wonder at her wisdom. Here's an example: «- Що ж таке відданість, дівчинко? - тихо запитав Олег.

${ }^{11}$ Скляренко С. Святослав. К.: Радян. письменник, 1968. С. 249.

12 Панова В. Ф. Сказание об Ольге. Панова В. Ф. Собр. соч.: В 5 m. Л.: Худож. лит., 1989. Т. 5. С. 6.

${ }^{13}$ Каргалов В. В. Святослав: Роман. Молодая гвардия. 1982. № 6. С. 95.

${ }^{14}$ Пономарёв С. А. Гроза над Русью. Тольятти: Русс, 1991. С. 94.

${ }^{15}$ Білик I. І. Похорон богів. К.: Радян. письменник, 1986. 574 с.

${ }^{16}$ Бабицька Т. М. Княгиня Ольга. К.: Молодь, 1990. С. 11.

${ }^{17}$ Ільницький М. М. Людина в історії: Сучасний український історичний роман. К.: Дніпро, 1989. С. 190. 
- Це коли завжди поруч - у щасті, у горі й занепаді» ${ }^{18}$.

Being a teen Olga says: «Мабуть, це добре, коли тебе бояться. Я б хотіла, щоб мене боялися. Вороги, звичайно, але й друзі трошки. Втім, у могутньої людини немає друзів. Тільки віддані люди. В мене буде багато таких. А свого чоловіка я зроблю князем» ${ }^{19}$. Т. Babitskaya may be exaggerating a bit, forcing her heroine to say things that would suit a mature person. However, in our view, these authorial efforts can be explained by the influence of the pictorial tradition. Emphasizing the wisdom of the girl, the writer seems to give the reader a peculiar setting for further perception of Olga's growth as a statesman.

Olga was brought to Kiev by Prince Oleg, who, in order to secure himself a reliable rear during his march to the Caspian Sea, took the daughter of the Pskov voivode hostage. It was on behalf of the prince, as T. Babitskaya says, that Olga got her name. Even M. Karamzin, wondering where it came from, wrote: "She took her name (Olga. - A.V), it seems, on behalf of Oleg, as a sign of their friendship with this worthy princess, or as a sign of Igor's love to him" ${ }^{20}$. In such a way he evoked the ironic reply of M. Pogodin, who believed that in the rough $10^{\text {th }}$ century there could not have been such exquisite courtesy that would have added honor to the $19^{\text {th }}$ century $^{21}$. Pogodin, who was inclined to recognize Olga as a Norman, wrote that her name, also Norman, came from Oleg's name ${ }^{22}$. Modern scholars, seeing the names of Olga and Oleg as a common root, derive the last name (Scandinavian-Slavic) from Helgi - "sacred" ${ }^{\text {"23 }}$. Perceiving the derivation of Olga's name, T. Babytskaya explains its formation in such way: the people of Kyiv, believing that Oleg (Olg) would take young Pskovian woman as a wife, began to call her: “дівиця Олега князя, отже - Ольга" 24 .

Prince Oleg, named by the chronicle "Prophetic" , - is an episodic character in the story, but his appeal to some extent may serve to characterize the artistic concept of Olga's image. Oleg's board has been called a "dark period" 25 by historians. Foreign sources do not even know

${ }^{18}$ Бабицька Т. М. Княгиня Ольга. С. 7.

${ }^{19}$ Бабицька Т. М. Княгиня Ольга. С. 8.

${ }^{20}$ Карамзин Н. М. История государства Российского. М.: Наука, 1989. Т. 1. С. 102.

${ }^{21}$ Погодин М. П. Нечто о роде великой княгини Ольги. С. 136.

22 Погодин М. П. Нечто о роде великой княгини Ольги. С. 136.

23 Лебедев Г. С. Эпоха викингов в Северной Европе. Л.: Изд-во ЛГУ, 1985. C. $214 .-215$.

${ }^{24}$ Бабицька Т. М. Княгиня Ольга. С. 12.

${ }^{25}$ Брайчевський М. Ю. Утвердження християнства на Русі. С. 81. 
his name or his activities ${ }^{26}$. Therefore, it is clear that T. Babitskaya was faced with the difficult task of "reviving" this mysterious figure of the early history of Rus by means of artistic words.

The writer does not provide a description of Oleg's appearance (the story is stingy on portrait characteristics). According to Oleg, we learn that he is sixty-three years old ${ }^{27}$. Once Oleg, "голоту нещасного", was kindly hosted by Ladogian Prince Ruric, "разом боролися за Новгород, за Київ ..."28. In those times, Oleg was a ruler and warrior glorified in the surrounding lands. But first of all, the writer is not interested in the foreign policy successes of the prince (which are discussed briefly), but his domestic politics, the essential principle of which is the well-known words "divide and rule" "Oleg shares the secrets of his power with Olga, because he liked her. The conversations with Oleg were not in vain for her. In the story we see that Olga later in her activities repeatedly followed the advice of the old prince.

Knowing her own self-worth, Olga offers herself to be a wife to Oleg. Olga is convinced that "разом вони могли б правити світом"30. However, Oleg was in no hurry with the decision, knowing well that "вона ніколи не буде чиєюсь, вона залишиться тільки собою. I той, хто візьме іiї за дружину, все життя біля неї прокрутиться" 31 . Still, Oleg underestimated Olga and realized this when he returned from a trip to the Caspian Sea. This mistake cost him his life.

Almost nothing is known about events related to the last years of the reign of Oleg. In this regard, B. Rybakov wrote that immediately after Oleg's march to Byzantium, "when a combined army of Slavic tribes and Varangians took indemnity from the Greeks, the "Grand Duke of Rus", as written in the 911 treaty, disappeared not only from the capital of Rus, but also in general from the Russian horizon"32. Only in 912, citing the text of the said treaty, "The Tale of Bygone Years" presents the famous legend of Oleg's death from a horse ${ }^{33}$. There is little information about foreign sources.

${ }^{26}$ Брайчевський М. Ю. Утвердження християнства на Русі. С. 80.

${ }^{27}$ Бабицька Т. М. Княгиня Ольга. С. 9.

${ }^{28}$ Бабицька Т. М. Княгиня Ольга. С. 6.

${ }^{29}$ Бабицька Т. М. Княгиня Ольга. С. 12 - 13.

${ }^{30}$ Бабицька Т. М. Княгиня Ольга. С. 18.

${ }^{31}$ Бабицька Т. М. Княгиня Ольга. С. 12.

32 Рыбаков Б. А. Киевская Русь и русские княжества ХП - ХШ вв. М.: Наука, 1982. C. $311-312$.

${ }^{33}$ Повість врем'яних літ. С. 56 - 59. 
T. Babitskaya offers her answer to a question that has long troubled researchers: what was the subsequent fate of Prince Oleg after his famous trip to Byzantium, dating from the chronicle of $907^{34}$. We learn from the story that Oleg, executing the allied duties enshrined in the treaty with the "царем царерадським", went to the Caspian Sea to fight the enemies of the empire. "Воював князь, - the author writes, - правда, з удачею, велику здобич узяв, але на зворотному шляху в Хазарії напали на нього арсії, мусульманські найманці хазарів, - мстилися за розгром своїх одновірців на Хвалинському (Каспійському. - А. В.) морі. Зовсім мало воїнів залишилося в Олега, здобичі взагалі ніякої",35. The source of the passage is the testimony of an Arab author of the $10^{\text {th }}$ century al-Masudi, who reports the losses (more than 30,000 people) suffered by the Russians on their way back ${ }^{36}$. This unfortunate period for the Russians began in 912, that is, the following year after the signing of the RussByzantine treaty ${ }^{37}$. Al-Masudi's message is consistent with the information of the Khazar document of the $10^{\text {th }}$ century that a certain Helgu-Oleg had mastered Tmutarakan shortly before the Caspian march ${ }^{38}$. Namely alMasudi writes about the Tmutarakan Rus people ${ }^{39}$. The Novgorod chronicle reports that shortly before his death Oleg went "over the sea", without specifying which sea it was $^{40}$ (in the scientific literature there is an opinion that it was the Black Sea ${ }^{41}$ ). So, sending Oleg to fight in the east, $\mathrm{T}$. Babitskaya presents her explanation of the mysterious disappearance of the prince from Kyiv, that has some documentary evidence.

While Oleg was fulfilling his obligations to Constantinople, a coup took place in Kyiv, where he left Igor. Olga became his main figure, according to T. Babitskaya. Marrying Igor, she already knew firmly that she would make her husband a prince. By bribery, flattery, not neglecting the spread of false rumors, Olga conspired Kyiv people against Oleg. When the prince returned from the campaign, Kyiv was already a hostile city to him. With no strength for the siege, Oleg had to go to Ladoga, which, according to B. Rybakov, was the base of the Normans in northern

\footnotetext{
${ }^{34}$ Повість врем'яних літ. С. $42-43$.

${ }^{35}$ Бабицька Т. М. Княгиня Ольга. С. 14.

${ }^{36}$ Сахаров А. Н. «Мы от рода русского...». Л.: Лениздат, 1986. С. 168 - 169.

${ }^{37}$ Сахаров А. Н. «Мы от рода русского...». С. 167.

${ }^{38}$ Котляр Н. Ф. Древняя Русь и Киев в летописных преданиях и легендах. К.: Наук. думка, 1986. С. 76.

${ }^{39}$ Котляр Н. Ф., Смолий В. А. История в жизнеописаниях. С. 31.

${ }^{40}$ Новгородская Первая летопись старшего и младшего изводов. М.-Л.: Изд-во АН

${ }^{41}$ Котляр Н. Ф., Смолий В. А. История в жизнеописаниях. С. 31.
} СCCP, 1950. С. 109. 
Rus $^{42}$. Here again, we see a "reconstruction" of events that could have been behind the stingy lines of the document: bearing in mind the message of the Novgorod Chronicle that Oleg had left for Ladoga ${ }^{43}$ before his death, the author shows the reasons that led the prince to such a step.

It seems that the chronicle of the death of the Prophetic Oleg is still being asked in the plot of the story. At one time, the nineteenth-century Russian writer Z. O. Volkonskaya did not resist the temptation to use it. She introduced in her "The Legend of Olga" (1820's (?)) an episode of the death of Oleg from the bite of a snake that crawled out of the skull of princely horse Athel ${ }^{44}$. And obviously, this is not surprising, because this translation is quite a winning from a creative point of view. Moreover, we don't know much about those times. How is this plot used in the story "Princess Olga"? Without dismissing some of the motives behind the chronicle narrative that extend to the Scandinavian saga of Orvar Odd, T. Babitskaya offers her vision of the situation that underpinned the famous story. Oleg in the story dies not from the bite of the snake, but the killer sent by Olga. The old prince was too dangerous rival in the power struggle. Realizing that Oleg can lead Varangians from the sea, Olga orders to kill him. And to avert suspicion, she spreads rumors that Oleg was bitten by the snake. That's how the legend was created.

Here is an illustrative passage in which Olga talks to the late Oleg who appeared in her morbid imagination: «- Часто стала кликати мене, княгиня, старієш. А свого часу ти не сумнівалася, як вчинити зі мною.

Ольга здригнулася.

- Мертві знають усе, - пояснив він.

Вона кволо оборонялася:

- Всі відають про те, що тебе вкусила змія.

Князь зареготав:

- Але цю змію звали твоїм іменем.

Ольга розгнівалася:

- Нічого дорікати мені. I ти вчинив би так само» ${ }^{45}$. As we can see, Olga was a worthy student of the prince, who, according to the chronicle, was involved in the murder of Askold and Dir. The last shelter of Oleg was

${ }^{42}$ Рыбаков Б. А. Киевская Русь и русские княжества ХП - ХШ вв. С. 310.

${ }^{43}$ Новгородская Первая летопись старшего и младшего изводов. С. 109.

44 Волконская 3. А. Сказание об Ольге. Волконская 3. А. Сочинения. Париж Карлсруэ, 1865. С. $98-99$.

45 Бабицька Т. М. Княгиня Ольга. С. $102-103$. 
Ladoga, where he got a mound" ("могыла" - according to the Novgorod chronicle $\left.{ }^{47}\right)$.

\section{The story base of "Princess Olga": socio-political and "home" aspects of the author's conception of the $10^{\text {th }}$ century in its encounters with other writers and researchers of the era}

After Oleg's death, the son of Rurik Igor became known as the ruler of Kyiv. The prince's desk got to him thanks to the efforts of Olga, who, knowing that she would never become a princess, made Igor the prince to rule Rus on his behalf. Even in the life of Oleg, she applauded his pupil Igor with a constant reminder that he was only the handyman of the mighty prince, “біля стремена Олегового ходить" ". To Igor's matchmakers Olga replied: “Я піду за Ігоря ... Тільки за князя Ігоря, за великого князя Київського" ${ }^{49}$. These Olga's words and the subsequent reaction to them by Igor and his circle, almost literally coincide with the corresponding place of the saga of Harald Harfagr, the hero to whom the beautiful Gude gave a pumpkin, motivating her act by the fact that he is not the conun of Norway ${ }^{50}$. Such a parallel in the story is obviously not accidental. First, it reflects the scientific point of view regarding the closeness of some of the details of Olga's chronicle to Scandinavian sources $^{51}$. Secondly, it allows the author to add into the characterization of Olga a colorful and yet real detail for the 10th century, without violating the traditional idea of the princess of Kyiv as a proud, imperious and energetic woman.

Igor as a statesman (this aspect is on the first place in T. Babitskaya's story) is significantly inferior to Olga. In fact, Rus was ruled not by him, but by his wife. But clever Olga skillfully hides her true role. "Позаяк вона хотіла, - T. Babitskaya writes, - щоб Русь була великою державою, а Ігор - великим державцем, ніхто не повинен бачити, що він під п'ятою в жінки" "52. Unaffected Igor is the complete opposite of the restrained and silent Oleg. T. Babitskaya's hero has no power over himself or his own people. Doing so he is different from Oleg, who was able to

\footnotetext{
${ }^{46}$ Бабицька Т. М. Княгиня Ольга. С. 156.

${ }^{47}$ Новгородская Первая летопись старшего и младшего изводов. С. 109.

${ }^{48}$ Бабицька Т. М. Княгиня Ольга. С. 15.

${ }^{49}$ Бабицька Т. М. Княгиня Ольга. С. 15.

${ }^{50}$ Снорри Стурлусон. Круг земной. М.: Наука, 1980. С. 43 - 44.

${ }^{51}$ Рыдзевская Е. А. Древняя Русь и Скандинавия. IX - XIV вв. М.: Наука, 1976.

${ }^{52}$ Бабицька Т. М. Княгиня Ольга. С. 59.
} С. $194-202$. 
hold his army in hand. Unstable to foreign influence, Igor readily persuades the Byzantine diplomat Theophanes, who, by rescuing the empire from the invasion of the northern barbarians (the campaign of Rus in $944^{53}$ ), skillfully avoids danger; quickly adheres to Olga's proposal to appoint a landlord to the land of Drevlyansk, without even thinking about the possible consequences of this step; he condones his younger squadrons, who by their voraciousness have driven the prince to the grave. $\mathrm{He}$ is devoid of Olga's foresight and sometimes acts contrary to her reasonable advice to satisfy his ambitions.

Igor's surroundings dislike their prince. And first of all - Olga, who feels for him - as to a person and as to a prince - disgust. Also in the story Igor is opposed to the warriors. Experienced senior combatants are outraged that Igor not only often neglects their right thoughts, but also tries to humiliate someone who has a different perspective of the princely. Igor's younger squads are dissatisfied with their prince because they received less prey in the Tsarigrad campaign than the one brought by the Varangian Sveneld from the Caspian Sea. Even the mercenary Sveneld, whose work is to wield a sword for Kyiv gold - is surprised at Igor's state myopia. And Kyiv's enemies Drevlyany consider the prince a "worthless successor" of Oleg. It is remarkable that in the story we almost do not see Igor, who would reflect on some state problem. Olga thinks of him. The prince is more willing to hunt and feast, his favorite theme is horses. "Про конец він може говорити цілий день" ${ }^{\text {, }}$, - characterizes her hero T. Babitskaya. Still, the writer does not deny the prince in positive features: Igor meets his death with dignity ${ }^{55}$.

The artistic concept of the image of Igor in the story "Princess Olga" is consistent with the point of view of some historians and writers. For example, S. Solovyov, and then S. Platonov, M. Pokrovsky, and others were inclined to characterize the prince of Kyiv as a worthless, self-loving and a miser human. A similar one-sidedness fell into the eye of M. Hrushevsky, who wrote about this: "In the Story (the chronicle - A.V.) Igor, tucked between two heroic princes - Oleg and Sviatoslav, is depicted, in contrast, indistinctly and unfriendly: he does not have that warlike temper, he has no military happiness, he is selfish - a great flaw in the eyes of his wife. Due to this fact, in the recent historiography, the characterization of Igor as a poor and unsympathetic prince has long been established. The characteristic, however, belongs entirely to the field of

\footnotetext{
${ }^{53}$ Повість врем'яних літ. С. $66-67$.

${ }^{54}$ Бабицька Т. М. Княгиня Ольга. С. 73.

${ }^{55}$ Бабицька Т. М. Княгиня Ольга. С. 96.
} 
fiction; we cannot rely on the characterization of folk legends, and the place that Igor occupies in the evolutionary process of the Rus state speaks strongly against it. It had to be energetic and capable in nature, when he did not allow so complicated and shaky state structure to collapse. First, we can take here a brief description of the older version of the Tale: " $и$ возрастшю же єму Игорю, и бысть храборъ и мудръ "56.

M. Hrushevsky's words have not lost their relevance even many years after they were written. In the historical prose of the last decades, Prince Igor is portrayed not so much as a statesman, but as a warrior of his army, for whom war and entertainment are above all. Here is what, for example, V. Kargalov writes in a novel "Sviatoslav": «Напрасно ждали своего охочего до развлечений князя тиуны та огнищанины, напрасно подстерегали его у ворот бояре и воеводы со своими заботами - у князя Игоря не находилось времени на скучные будничые дела. Он искренне верил, что лишь пиры, охота и война достойны его внимания.

Само собой получилось, что люди, отчаявшиеся дождаться княжеского внимания, стали искать суда у княгини Ольги. <...> Игорь же мечтал прославить свое имя походом на Царьград, как прославился и остался жить в дружинных поминальных песнях вещий Олег» ${ }^{57}$. V. Kargalov's point of view broadly coincides with the position of I. Bilyk (in "The funeral of Gods" Igor is treated as a prince-unwell), S. Ponomaryov (in "Thunderstorm above Rus" it is underlined Olga's dislike for "cautious and stingy", "indecisive" prince ${ }^{58}$ ) and others.

On the other hand, some of the writers endow Igor with the qualities of a shrewd, visionary ruler, tieing his name with the strengthening of Rus. This applies, for example, to S. Sklyarenko, who characterized Igor as a wise and courageous prince, B. Komar, whose hero is portrayed as a supporter of the interests of the state (the story "Squirell" $(1960){ }^{59}$ ). In the historical science of recent times the prince was similarly characterized in the works of M. Polovy, A. Sakharov and others.

The fullest disclosure of Olga's abilities as a wise ruler are in the story of T. Babitskaya after Igor's death, when Olga lay on her shoulders the entire burden of state power. The record of the actions of this period reflected the main features of her personality - wisdom, authority, cruelty.

56 Грушевський М. С. Історія України-Руси. К.: Наук. думка, 1991. Т. 1. C. $445-446$.

${ }^{57}$ Каргалов В. В. Святослав: Роман. С. 103.

${ }^{58}$ Пономарёв С. А. Гроза над Русью. С. 95 - 96.

${ }^{59}$ Комар Б. А. Векша. Странствующий вулкан. К., 1984. С. 114, 116 - 117. 
T. Babitskaya retains the historical basis of character, focusing on these qualities of the princess. In this way the heroine of our author differs, for example, from V. Panova's heroine Olga. In "The legend of Olga", this writer is interested in Olga first of all as "a baby-girl, girl, wife, widow, mother, mistress" $"$.

Much space in T. Babitskaya's story was given to the activities of the princess in ordering the Rus lands. The main rivals of the Kyiv table here are the Drevlyans. By his extortion, Igor exacerbated relations between Kyiv and Iskorosten, which expectedly led to the Drevlyans uprising. The roots of this confrontation go back to the ancient times. "Вони (Drevlyans$A$. V.) Києву як були ворогами з часів Кия, так і лишилися" "61, - Olga says. The memory of the events of several hundred years of enmity lived in the minds of the Drevlyans, prevented them from quenching the freedomloving sparks that roasted under a layer of outer obedience. It is known from the chronicle sources that the princes of Kyiv repeatedly had to "примучувати" rebellious neighbors. One of the uprisings, which by the "The Tale of Bygone Years" took place in the year $913^{62}$, was also attended by T. Babitskaya's hero, Prince of Drevlyans people - Mal, then still "юний і нерозважний" 63 . The longing for the former might of the Drevlyan's land is felt in the words of the story's heroes, who form the "opposition" to Drevlyans' camp (Tuzhir, Radonega, Sukhan). But, as the potter Suhan remarked, "не вернеться минуле"64: Kyiv was constantly extending its power to the land of the Drevlyans.

The chronicle of the three revenges of Igor's widow Olga, T. Babitskaya treats with a great care. Aware of his folklore origin, the writer uses only the legend of a sober after Igor, where five thousand Drevlyans were killed (Olga's "third revenge" ${ }^{\text {"65 }}$ ). This episode naturally fits in with the events that took place after the death of the Prince of Kyiv. After all, as S. Solovyov wrote, "with the underdeveloped social relations then, revenge for a relative was mostly a feat; that is why the story of such a feat aroused the general live attention, and so it is so freshly and beautifully preserved in the memory of the people. $\langle\ldots\rangle$ the one who had a holy duty of vengeance was a hero of truth, and the more cruel the revenge

${ }^{60}$ Нинов А. А. Примечания. Панова В. Ф. Собр. соч.: В 5 m. Л.: Худож. лит., 1989.

T. 5. C. 547.

${ }^{61}$ Бабицька Т. М. Княгиня Ольга. С. 102.

${ }^{62}$ Повість врем'яних літ. С. $62-63$.

${ }^{63}$ Бабицька Т. М. Княгиня Ольга. С. 90.

${ }^{64}$ Бабицька Т. М. Княгиня Ольга. С. 54.

${ }^{65}$ Повість врем'яних літ. С. $86-87$. 
was, the more pleased the society of that time was, the more it glorified the butcher as a worthy relative" ${ }^{66}$. In the light of these words, the reaction of the Drevlyans to Olga's revenge at first glance is understood: "Помстившись так страшно, княгиня високо піднеслася в їхніх очах, адже над усе вони шанували рід"67. We add that the appeal to the chronicle of the plot gave T. Babitskaya the opportunity to decorate the story with a colorful picture of the funeral rite ${ }^{68}$, the description of which is borrowed from the Arab author of the $10^{\text {th }}$ century Ibn Fadlan ${ }^{69}$.

Following the chronology of the events, the author outlines the further course of Olga's struggle with Prince Mal, who, having been defeated in the battle, hid in Iskorosten. Using lightning arrows (not birds like it was in the chronicle ${ }^{70}$ ), Olga's soldiers burned the city. The last prince of Drevlians people Mal was suffocated in smoke ${ }^{71}$. After that Drevlyans land once again became a part of the Kyiv state.

It should be noted that the author's concept of the eternal confrontation of Polyans and Drevlyans has a certain historiographical basis. It, apparently, is based on the existing assumption about the ancient belonging of Kyiv to the Drevlyans land, which was stated by I. Zabelin ${ }^{72}$. Archaeological excavations of the 1970s on the top of Starokyivska Gora revealed a cultural layer of the $6^{\text {th }}$ century with ceramics of the Drevlyans type $^{73}$. It was suggested that in the $6^{\text {th }}$ century there was a Drevlyan's village, which in the $7^{\text {th }}$ century was seized by Polyans Prince Kyi. Kyi built in this place a fortress named after him. In due time, scientists noted that Kyiv was obliged by its exaltation to war of Polyans with the Drevlyans $^{74}$. It should be said that the "Drevlyanska" concept was in demand in historical prose. For example, in "The funeral of Gods" by I. Bilyk, Y. Jejula's novel "New Sky", the era of Igor and Olga is presented as the dramatic finale of a long-running battle between two powerful rivals - Kyiv and Iskorosten, which ended with the conquest of the Drevlyans $^{75}$. Actually, we see the same in T. Babitskaya's work.

66 Соловьев С. М. История России с древнейших времён. Соловьев С. М. Сочинения. М.: Мысль, 1988. Кн. 1. Т. 1 - 2. С. 147.

${ }^{67}$ Бабицька Т. М. Княгиня Ольга. С. 113.

${ }^{68}$ Бабицька Т. М. Княгиня Ольга. С. $107-110$.

${ }^{69}$ Славяне и скандинавы. М.: Прогресс, 1986. С. 70 - 73.

70 Повість врем'яних літ. С. $90-91$.

${ }^{71}$ Бабицька Т. М. Княгиня Ольга. С. 132.

72 Членов А. М. По следам Добрыни. М., 1986. С. 148.

73 Членов А. М. По следам Добрыни. С. 151.

74 Членов А. М. По следам Добрыни. С. 153.

75 Джеджула Ю. Новое небо. К. Радян. письменник, 1989. 399 с. 
The story of "Princess Olga" ends with a description of the Kyiv's ruler trip to Constantinople. Describing this visit, the writer has encountered some difficulties, because historians still have no unanimous opinion on the purpose, content and results of the Rus-Byzantine negotiations. P. Tolochko on this occasion suggested that Olga and Konstantin Bagryanorodny discussed issues of a trade and economic nature, confirming the provisions of the 944 treaty, as well as the problem of the Christianization of Rus ${ }^{76}$. Today, the question as to when, where and under what circumstances Olga was baptized remains open. If chronicle and hieroglyphic sources link this event to being in Constantinople, then there is still no such unanimity among the researchers.

Having thought of “дати русичам нову віру, грецьку", T. Babitskaya's heroine goes to Constantinople. But it is not the only thing that excites the princess. However, if the issue of increasing the Byzantine tribute to Rus and the security of the Rus borders from the Pechenegs was resolved, the problems of duty-free trade for Kyiv merchants and dynastic marriage remained unresolved.

Focusing on the chronicle, as well as on the works of S. Solovyov, A. Sakharov, V. Pashut, T. Babitskaya writes about the baptism of Olga in Byzantium. Thus, she draws closer to V. Panova, who relied on ancient Rus sources $^{77}$, and at the same time disagrees with S. Sklyarenko, whose Olga has already been baptized in Constantinople. If S. Sklyarenko, casting aside the chronicle of Olga's baptism in Byzantium and Konstantin Bagryanorodny's courtship, tells of the important political and economic negotiations of the Princess ${ }^{78}$, then there are several other accents in the story "Princess Olga". T. Babitskaya, like her predecessor, leaving aside the "chronicle of fables" about the emperor's courtship, focuses not so much on the negotiation process as on the psychological state of Olga, who was on the verge of a new faith. In Kyiv, Olga realized that a Christian god, who "з жодним племенем не зв'язаний, а найголовніше - чужий для роду" 79 , can give her power of a new quality. But it was only in the church of St. Sophia in Constantinople that the princess, fascinated by "неземною музикою" made it clear that the new faith was also the way to inner renewal, peace and harmony. «Музика розчулила ऑï до сліз.

76 Толочко П. П. Древняя Русь: очерки социально-политической истории. К.: Наук. думка, 1987. С. 42.

${ }^{77}$ Повість врем'яних літ. С. $92-93$.

78 Чумак В. Г. Семен Скляренко: Літературно-критичний нарис. К.: Радян. письменник, 1972. С. 159.

${ }^{79}$ Бабицька Т. М. Княгиня Ольга. С. 165. 
Повільно напливала вона на княгиню, і душа ії купалася в цих звуках, як у літеплі, звільняючись від лжі, бруду і всього, що накопичилось за довгі-довгі роки життя та володарювання. Серце защеміло від почуття непоправності минулого і страшної провини, але солодкі голоси, що лилися зусібіч, переконували, що все ще можна спокутувати» ${ }^{80}$. In this scene, the author portrays not an austere and powerful ruler, but an old woman, tired of a difficult life, which required the utmost exertion of physical and moral forces. This view is a good touch to the princess' colorful psychological portrait created in the story.

Proving that Olga became a Christian even before her visit to Constantinople, S. Sklyarenko emphasizes to some extent her independence from the Byzantine emperor ${ }^{81}$. Since T. Babitskaya's Olga was baptized in the capital of Byzantium, her patriotic feelings have not diminished at all. The composition of the princess' character does not allow her to think that she is able to yield to the emperor at the expense of Rus. "Princess Olga бажала для Русі високої долі. Щоб велика, могутня, багатолюдна держава стала взірцем для інших царств"82.

\section{CONCLUSIONS}

Appealing in the story "Princess Olga" to the important for the East Slavic history era of the first descendants of Rurik, T. Babitskaya first of all drew facts, plot collisions and interpretations from the chronicle heritage, modeling of which is generally related to the scientific work of the past and nowadays studies (works of M. Pogodin, M. Hrushevsky, O. Rydzevska, V. Pashut, B. Rybakov, M. Brychevsky, P. Tolochko, A. Sakharov, M. Kotlyar, etc.). From this material, the writer first of all selected the one that most suited her author's intention - to create images of the Kyiv statesmen, to reflect (of course, in the language of artistic creativity) the leading socio-political tendencies of the chosen era. The image of the chronicles of the Rus rulers Olga, Oleg and Igor by the writer, on the one hand, is marked by the originality of the author's approach against the background of other writer's interpretations (Z. Volkonskaya, I. Bilyk), and on the other - executed in the focus of traditional imaginative experience (S. Sklyarenko, V. Panova, V. Kargalov, S. Ponomaryov). A special place in T. Babitskaya's story takes the author's reconstruction of events, which are briefly reported by domestic or foreign sources. The scanty lines of the document act here as a kind of impulse to

\footnotetext{
${ }^{80}$ Бабицька Т. М. Princess Olga. C. 175.

${ }^{81}$ Чумак В. Г. Семен Скляренко: Літературно-критичний нарис. С. 159.

82 Бабицька Т. M. Princess Olga. C. 186.
} 
create an original reconstruction of a situation that may have polemical color. And this already testifies to the appropriate level of historical thinking, characterizes the writer as a thoughtful researcher.

The events of the historical source overgrow in the "Princess Olga" with motivated details, get a psychological connotation, fit logically into the story canvas. The fact used here relates to T. Babitskaya with the characters of the heroes, the relationships of the historical persons acting in the work, "working" on the author's conception of a certain image and historical situation (Prince Oleg's plot line, "Drevlyans" collisions of the story, etc.).

\section{SUMMARY}

The aim of the article is to make an attempt to characterize T. Babitskaya's story "Princess Olga", to look through the works about Kievan Rus of V. Panova ("The legend of Olga"), S. Sklyarenko ("Sviatoslav"), V. Kargalov ("Sviatoslav"), S. Ponomaryov ("Thunderstorm above Rus"), I. Bilyk ("The funeral of Gods"), etc. in the historical and literary context. The author seeks to find out the conceptual features of the approaches of these writers to the artistic reconstruction of ancient Rus reality, the nature of the usage of source materials. At the same time, the achievement of the historiographic thought of both the previous and the contemporary prose is taken into consideration, which expands the understanding of the connection between scientific experience and artistic creativity. We are also aware of the expediency and fruitfulness of the identification of figurative traditions in the works of these authors, which date back to the historical prose of the $19^{\text {th }}$ century. The substantive originality of the novels and stories selected for analysis is in line with the writer's principles of using the source, attention is paid to the specifics of the artistic generalization of the documented features of early medieval reality and its reflection. The content of the publication helps to understand more precisely the specifics of the creative position of the author's "Princess Olga", to clarify the original features of artistic and historical works of V. Panova, V. Kargalov, I. Bilyk and others. The results of the study may lead to the conclusion that further consideration of these issues will be relevant to characterize both the literary process of the $60-$ 90 years of the last century as a whole and to assess the creative skill of a particular artist.

\section{REFERENCES}

1. Бабицька Т. М. Княгиня Ольга. К.: Молодь, 1990. 216 с.

2. Білик І. І. Похорон богів. К.: Радян. письменник, 1986. 574 с. 
3. Брайчевський М. Ю. Утвердження християнства на Русі. К.: Наук. думка, 1988. 262 с.

4. Воеводин С. Ошибка Вещего Олега: Роман. Х.: Клуб семейного досуга, 2019. 256 с.

5. Воеводин С. Ратник княгини Ольги: Роман. Х.: Клуб семейного досуга, 2018. 288 с.

6. Волконская 3. А. Сказание об Ольге. Волконская 3. A. Сочинения. Париж- Карлсруэ, 1865. С. 37 - 150.

7. Грушевський М. С. Історія України-Руси. К.: Наук. думка, 1991. T. $1.736 \mathrm{c.}$

8. Джеджула Ю. Новое небо. К. Радян. письменник, 1989. 399 с.

9. Житіє Ольги. Дерево пам'яті: Книга українського історичного оповідання. К.: Веселка, 1990. Вип. 1. С. $154-162$.

10. Ільницький М. М. Людина в історії: Сучасний український історичний роман. К.: Дніпро, 1989.356 с.

11. Карамзин Н. М. История государства Российского. М.: Наука, 1989. Т. $1.640 \mathrm{c.}$

12. Каргалов В. В. Святослав: Роман. Молодая гвардия. 1982. № 6. C. $93-184$.

13. Колінько О. П. «Анна Київська - королева Франції» В. Чемериса: художня чи квазі-біографія. Наукові записки Бердянського державного педагогічного університету. 2017. Вип. XII. С. $181-187$.

14. Комар Б. А. Векша. Странствующий вулкан. К.: Веселка, 1984. $176 \mathrm{c}$.

15. Котляр Н. Ф. Древняя Русь и Киев в летописных преданиях и легендах. К.: Наук. думка, 1986. 160 с.

16. Котляр Н. Ф., Смолий В. А. История в жизнеописаниях. К.: Наук. думка, 1990. 256 с.

17. Лебедев Г. С. Эпоха викингов в Северной Европе. Л.: Изд-во ЛГУ, 1985. $288 \mathrm{c.}$

18. Літвинчук Т. Художня рецепція дихотомії «місто - степ» в історичних романах П. Загребельного, Р. Іванченко та П. Угляренка. Синопсис: текст, контекст, медіа. 2019. № 25 (1). С. 31 - 39.

19. Нинов А. А. Примечания. Панова В. Ф. Собр. соч.: В 5 m. Л.: Худож. лит., 1989. Т. 5. С. 545 - 558.

20. Новгородская Первая летопись старшего и младшего изводов. М.-Л.: Изд-во АН СССР, 1950. 651 с.

21. Панова В. Ф. Сказание об Ольге. Панова В. Ф. Собр. соч.: В 5 m. Л.: Худож. лит., 1989. Т. 5. С. $6-51$. 
22. Пашуто В. Т. Внешняя политика Древней Руси. М.: Наука, $1968.472 \mathrm{c}$.

23. Повість врем'яних літ: Літопис (За Іпатським списком). К.: Радян. письменник, 1990. 558 с.

24. Погодин М. П. Нечто о роде великой княгини Ольги. Tpyды $u$ летописи Общества истории и древностей Российских. 1828. Ч. IV. Кн. 1. C. $130-138$.

25. Пономарёв С. А. Гроза над Русью. Тольятти: Русс, 1991. 336 с.

26. Пушкарёва Н. Л. Женщины Древней Руси. М.: Мысль, 1989. $287 \mathrm{c}$.

27. Рыбаков Б. А. Киевская Русь и русские княжества ХП ХШ вв. М.: Наука, 1982. 592 с.

28. Рыдзевская Е. А. Древняя Русь и Скандинавия. IX - XIV вв. М.: Наука, 1976. 240 с.

29. Сахаров А. Н. «Мы от рода русского...». Л.: Лениздат, 1986. $344 \mathrm{c}$.

30. Скляренко С. Святослав. К.: Радян. письменник, 1968. 663 с.

31. Славяне и скандинавы. М.: Прогресс, 1986. 416 с.

32. Снорри Стурлусон. Круг земной. М.: Наука, 1980. 688 с.

33. Соловьев С. М. История России с древнейших времён. Соловьев С. М. Сочинения. М.: Мысль, 1988. Кн. 1. Т. 1 - 2. 798 с.

34. Сушкевич Т. Часопросторове «пограниччя» у романах про Київську Русь Павла Загребельного. Вісник Львівського університету. Серія філологічна. 2014. Вип. 60. Ч. 2. С. $276-283$.

35. Толочко П. П. Древняя Русь: очерки социально-политической истории. К.: Наук. думка, 1987. 247 с.

36. Членов А. М. По следам Добрыни. М.: Физкультура и спорт, 1986. $287 \mathrm{c.}$

37. Чумак В. Г. Семен Скляренко: Літературно-критичний нарис. К.: Радян. письменник, 1972. 247 с.

38. Шлецер А.-Л. Нестор. СПб., 1816. Ч. 2. 4, 832 с.

39. Яворівський В. У мене вечеряв Ісус. Княгиня Ольга - велика грішниця, яка стала святою. К.: Брайт Букс, 2019. 344 с.

\section{Information about the author:}

Vysotsky A. A.

Candidate of Philological Sciences, Associate Professor at the Department of World Literature and Culture named after professor O. Mishukov, Kherson State University 27, 40 rokiv Zhovtnya str., Kherson, 73000, Ukraine 
NOTES 
NOTES 
NOTES 
Publishing house "Liha-Pres"

9 Kastelivka str., Lviv, 79012, Ukraine 44 Lubicka str., Toruń, 87-100, Poland

Printed by the publishing house "Liha-Pres"

Passed for printing: September 17, 2019.

A run of 150 copies. 